\title{
Lycopsida from the lower Westphalian (Middle Pennsylvanian) of the Maritime Provinces, Canada
}

\author{
Carmen Álvarez-VÁzquez ${ }^{*}$ and Robert H. Wagner \\ Centro Paleobotánico, IMGEMA — Real Jardín Botánico de Córdoba, Avenida de Linneo, s/n, \\ 14004 Córdoba, Spain \\ *Corresponding author <paleo.calvarez@jardinbotanicodecordoba.com>
}

Date received 20 May 2013 g date accepted 07 February 2014

\begin{abstract}
A taxonomic revision of lycopsids is presented as part of a reassesment of lower to middle Westphalian adpression floras from the Maritime Provinces of Canada. Being elements of the swamp flora their record reflects sedimentary bias. Systematic collecting from the "Fern Ledges" at Saint John (New Brunswick) has yielded only a few lycopsid remains as a result of the allochthonous facies. Most records (mainly by W.A. Bell in the twentieth century) correspond to sporadic collecting by Geological Survey of Canada (GSC) personnel. Their specimens are kept in GSC Ottawa. Additional remains are in museums at Montréal (Quebec), Joggins (Nova Scotia) and Saint John (New Brunswick). We introduce a new species (Lepidodendron bellii), and reinstate another (Diaphorodendron decurtatum) described by Dawson in the 19th century. Altogether, 26 taxa are described, including stem and branch remains as well as roots, leaves, strobili and sporophylls. Three specimens are illustrated from localities outside Canada so as to clarify specific characters. A copy of Lindley and Hutton's illustration of the type of Lepidodendron dilatatum (here recorded as Bergeria dilatata) is figured in the context of a redefinition of the genus Bergeria for stem remains with false leaf scars. Problems surrounding the morphological interpretation of arborescent lycopsids of Pennsylvanian age are discussed, and the stratigraphic and paleogeographic distribution are recorded for the different taxa. The identity of the Pennsylvanian flora of the Canadian Maritimes with that of the British Isles and western Europe in general is emphasized by the synonymies discussed. Paleogeographic proximity and a similar paleolatitude justify the identity of floras.
\end{abstract}

\section{RÉSUMÉ}

Une révision taxonomique des lycopsides est présentée dans le cadre d'une réévaluation des compressionsimpressions des flores du Westphalien inférieur et moyen des Provinces maritimes canadiennes. Comme membres de la flore marécageuse, leur enregistrement est conditionné par l'environnement. Le prélèvement systématique dans les «Fern Ledges » à Saint John (Nouveau-Brunswick) n’a permis que récupérer des quelques fragments indeterminables de lycopsides en raison du faciès allochtone. La plupart des enregistrements (principalement par W. A. Bell au XXe siècle) correspondent au prélèvement sporadique effectué par le personnel de la Commission géologique du Canada (CGC). Leurs spécimens sont conservés à CGC-Ottawa. Les autres échantillons sont dans des musées à Montréal (Québec), à Joggins (Nouvelle-Écosse) et à Saint John (NouveauBrunswick). Nous introduisons une nouvelle espèce (Lepidodendron bellii) et nous revalidons une autre (Diaphorodendron decurtatum) décrite par Dawson au XIXe siècle. En tout, 26 taxons sont décrits, y compris des échantillons de tige et de branche, de même que les racines, les feuilles, les strobiles et les sporophylles. Trois spécimens de localités situées hors du Canada sont illustrés dans le but de clarifier leurs caractéristiques 
spécifiques. Une copie de l'illustration de Lindley et Hutton du type de Lepidodendron dilatatum (ici répertorié sous le nom de Bergeria dilatata) est incluse dans le contexte d'une redéfinition du genre Bergeria pour des tiges présentant de fausses cicatrices foliaires. Les problèmes entourant l'interprétation morphologique des lycopsides arborescents du Pennsylvanien sont analysés, et les distributions stratigraphiques et paléogéographiques sont enregistrées pour les différents taxons. Il est mise en évidence que la flore pennsylvanienne des Provinces maritimes canadiennes est identique avec celle des Îles Britanniques et de l'Europe occidentale en général et les listes de synonymie en sont le témoin. La proximité paléogéographique et une paléolatitude similaire justifient l'identité entre les flores.

[Traduit par la redaction]

\section{INTRODUCTION}

This paper forms part of a series of taxonomic revisions of upper Namurian and, more particularly, lower Westphalian floras of Nova Scotia and New Brunswick. This study was undertaken with the active support of the Geological Survey of Canada (GSC) and the New Brunswick Museum, as well as other institutions in Nova Scotia. John Utting of the GSC was the prime mover to effect this revision, which should lead to a synthesis of paleobotanical and palynological data for the stratigraphy and paleogeography of the Pennsylvanian in eastern Canada. Geologically, the material is from the socalled Maritimes Basin, an entity which has been subject to structural controls of various kinds, leading to separate areas of downwarp that may be regarded as subsidiary basins, an example of which is the Cumberland Basin. Although a paper dealing with a taxonomic revision of part of the flora is not the place to go into geological detail, it is useful to observe that the Pennsylvanian floras of the Maritime Provinces of Canada compare most closely with those of the British Isles, a fact recognized by previous authors such as M.C. Stopes and W.A. Bell. Thus, Nova Scotia, linked to Newfoundland, may have been in continuity with the Midland Valley and the adjacent Southern Uplands of Scotland, a possibility important in a floral context and to be discussed in a later, more general paper. Our revisions commenced with a paper on extrabasinal floral elements (Wagner 2001) and was continued in Wagner (2005a, b), Wagner (2008) and Wagner and Álvarez-Vázquez (2008).

Most of the present paper, the largest contribution to date in the series of revisions, involves material described by Walter A. Bell in the early part of the twentieth century. In order to place Bell's work in its proper perspective, the enormous range of his investigations is noted not only with regard to the time intervals covered, but also the number of fossil floras and faunas recorded and the stratigraphic conclusions that were drawn. In this context, it is understandable that an in-depth revision of fossil identifications reveals gaps in the consideration of taxa and the consequent introduction of unneccesary species. This may be ascribed in part to incomplete consultation of the literature in German and French. Wartime conditions may have been partly responsible by cutting his links with continental Europe.
The Cumberland Basin in Nova Scotia includes the world-famous Joggins section on Chignecto Bay, an inner arm of the Bay of Fundy. This section has been declared a World Heritage Site by UNESCO (Calder 2007, 2009). Early work at Joggins includes that of Dawson (1868), who also described a number of fossil plant species from the Fern Ledges locality at Saint John, New Brunswick, on the northwestern side of the Bay of Fundy. The Fern Ledges flora was redescribed by Stopes (1914), and the Cumberland Basin flora was recorded in a memoir by Bell (1944), supplemented by selected illustrations in Bell (1966). In 1940, Bell also reported on material from the Pictou coalfield, representing deposits in the Stellarton Basin, a small pull-apart basin in northern Nova Scotia. The present revision is restricted almost entirely to material from the lower Westphalian of the Cumberland Basin, with occasional specimens from the Stellarton Basin. No material from Saint John is included in the present paper as lycopsid remains are virtually absent from Fern Ledges. Stopes (1914) commented on the few scraps of lycopsid leaves and decorticated branch and stem fragments, which she correctly regarded as indeterminable. She figured a fragment recorded previously as Sigillaria palpebra (Dawson 1862), calling it Sigillaria sp. (indeterminable) (Stopes 1914, pl. V, fig. 8). We concur with its designation as "indeterminable". The plant fragments preserved at Fern Ledges are drifted remains that include a large proportion of comminuted plant debris. Falcon-Lang and Miller (2007) also mention rooted vegetation, but their description of plants in growth position (p. 952) conflicts with personal observation by one of the present writers (RHW) and with an examination of a rock specimen that was kindly made available by Dr R.F. Miller. The fact that the Fern Ledges material represents an allochthonous assemblage explains the virtual absence of lycopsid remains, as well as the poor preservation of the few (drifted) specimens recorded.

Bell (1944) distinguished Riversdale and Cumberland groups, but recent authors have incorporated Riversdale strata in the Mabou Group. Several formations are now recognized in the Joggins section, which is the principal area of outcrop in the Cumberland Basin (Gibling et al. 2008). These can be dated on plant megafossils as ranging from possible Yeadonian to possible Bolsovian, but most of this classic section corresponds to the Langsettian according 
to the present authors and subject to consultation with palynological colleagues. Coal workings in Nova Scotia provided a large number of the plant megafossils of Langsettian age in the collections of the Geological Survey of Canada in Ottawa. We have had access to this collection, which includes all the material recorded by Bell $(1944,1966)$ as well as some additional specimens that were unrecorded by Bell. The Dawson Collection at the Redpath Museum, McGill University, Montreal, has been examined as well, albeit more succinctly.

In the present paper, all the lycopsid taxa previously described from the Cumberland and Stellarton basins are revised, thus facilitating a full comparison with the same taxa in western Europe. A few lower Westphalian lycopsid remains from western Spain are figured for comparison in cases where the Canadian material is too poorly preserved or very fragmentary. Walter Bell was keenly aware of the close similarity of Carboniferous plant taxa from the Maritimes with those of western Europe, especially the British Isles. The Carboniferous floras of Great Britain have been documented comprehensively by Kidston (e.g., 1893, 1903, 1916) and Crookall (1964, 1966). Bell seemed less familiar with the paleobotanical literature in French and German, a factor that may have imposed limitations on his identifications. Although Bell collected many specimens himself, most of the material he recorded was collected during field mapping by other geologists. Inevitably, this resulted in more sporadic records and, often, fragmentary remains. There is little evidence from Bell's work of largescale collecting from single localities. Assiduous collecting from the Joggins shore by Donald Reid has yielded some of the lycopsid remains recorded in the present paper.

The lycopsids are generally regarded as swamp elements adapted to a high water table and, in a few cases, some degree of salinity. With a few exceptions, their biostratigraphic value seems limited. This may be due to evolutionary conservatism as well as the limited range of morphological characters preserved in impression floras.

Stratigraphic occurrences are given in accordance with the western European regional chronostratigraphic subdivisions of the Pennsylvanian Subsystem (Fig. 1). Mention of international stages linked to eastern European marine records is avoided due to discrepancies in the correlation with the western European regional scale.

\section{LATE CARBONIFEROUS (PENNSYLVANIAN) ARBORESCENT LYCOPSIDS: A GENERAL COMMENTARY}

The remains of large, arborescent lycopsids in coalbearing deposits of Pennsylvanian age have generally fascinated paleobotanists and coal geologists. The predominant role of lycopsids in coal formation is generally acknowledged (e.g., DiMichele and Phillips 1985), and is particularly obvious from palynological data (e.g., Peppers 1996). Large external impressions of lycopsid trees caught the eye of the early paleobotanists, particularly those connected with coal mining (e.g., Graf Kaspar von Sternberg, whose last resting place, near Radnice in Bohemia, is adorned by a superb specimen of Lepidodendron aculeatum). The internal anatomy of these plants was studied later, when coal balls were collected. The different kinds of preservation, primarily of external morphology versus anatomical detail, gave rise to a parallel taxonomic treatments, which has been integrated only to a certain extent (e.g., DiMichele 1983) because of the incomplete overlap of characters.

The reconstruction of lycopsid trees has been problematical. Stem impressions only rarely have leaves attached, whereas leaves are common on the remains of smaller branches. Thus, older reconstructions by Hirmer (1927), Eggert (1961), as well as more recent ones (e.g., Opluštil 2010), show stems devoid of leaves, while the upper parts of trees, profusely branched or not, are depicted with single-veined leaves of various lengths and densities of arrangement. The general assumption has been that lycopsids would have shed leaves from the lower part of the trees as they grew, their former presence being shown by leaf scars on protruding parts of the leaf cushions. However, this assumption needs to be questioned in several cases, if not generally. Lycopsids are characterized by a wide area of cortical tissue surrounded by a thick-walled periderm. These trees had only a very small wood cylinder. When trees fell, this overall structure resulted in tissue collapse and flattening of trunks before entombment, processes that may have taken place quite quickly. Indeed, it is common to find totally flattened remains of lycopsid tree trunks, the imprints of both sides separated by only a few millimetres of sediment, with or without a coaly substance representing the collapsed tissue. In the case of sizeable stem and branch remains, the only possibility of finding clearly attached leaves preserved as adpressions is on the margins of the flattened remains (even though careful preparation may also reveal the presence of attached leaves below, in a position external to the compression). The larger the original stem or branch diameter, the less likely it becomes to actually find such margins preserved, taking into account that the remains are always fragmentary. Indeed, flattened slabs of large tree trunk impressions generally show only leaf scars, not the actual leaves. Recognition of this preservational character is important, because it means that the apparent absence of leaves from major stem remains does not necessarily mean their absence before fossilization. The discovery of occasional larger specimens with attached leaves confirms the validity of this statement. There is also no apparent reason why these trees, living in a tropical swamp environment should have had a caducous habit. This does not mean, of course, that some of the larger trees would not 


\begin{tabular}{|c|c|c|c|c|c|}
\hline$\underset{⿱ 亠 凶}{\frac{5}{\omega}}$ & ஸ่ & SERIES & GLOBAL STAGES & $\begin{array}{l}\text { SUBSTAGES } \\
\text { (W. Europe) }\end{array}$ & 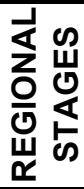 \\
\hline \multirow{7}{*}{ 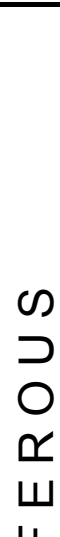 } & \multirow[b]{5}{*}{$z$} & \multirow{5}{*}{ UPPER } & \multirow{2}{*}{ GZHELIAN } & $\begin{array}{l}\text { middle to upper } \\
\text { Autunian }\end{array}$ & \multirow{6}{*}{ 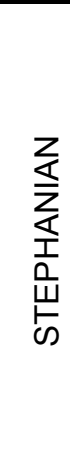 } \\
\hline & & & & $\begin{array}{c}\text { Stephanian C } \\
\text { (= lower Autunian) }\end{array}$ & \\
\hline & & & \multirow{4}{*}{ KASIMOVIAN } & Stephanian B & \\
\hline & & & & "Saberian" & \\
\hline & & & & Barruelian & \\
\hline & \multirow{10}{*}{$\begin{array}{l}\bar{z} \\
z \\
\varangle \\
> \\
\square \\
> \\
\omega \\
z \\
z \\
w \\
\square\end{array}$} & \multirow{5}{*}{ MIDDLE } & & Cantabrian & \\
\hline & & & \multirow{4}{*}{ MOSCOVIAN } & Asturian & \multirow{4}{*}{ 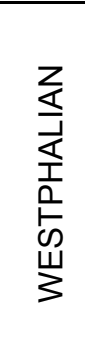 } \\
\hline \multirow{8}{*}{$\begin{array}{l}\bar{Z} \\
0 \\
\infty \\
\alpha \\
\varangle \\
u\end{array}$} & & & & Bolsovian & \\
\hline & & & & Duckmantian & \\
\hline & & & & Langsettian & \\
\hline & & \multirow{5}{*}{ LOWER } & \multirow{5}{*}{ BASHKIRIAN } & Yeadonian & \multirow{5}{*}{ 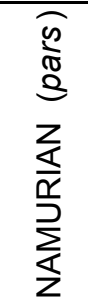 } \\
\hline & & & & Marsdenian & \\
\hline & & & & Kinderscoutian & \\
\hline & & & & Alportian & \\
\hline & & & & Chokierian & \\
\hline
\end{tabular}

Figure 1. Series, stages and substages of the Pennsylvanian Subsystem in western Europe, showing their position with regard to the stages of international usage (after Wagner and Álvarez-Vázquez 2010, fig. 7). Note that the base of Moscovian is placed in accordance with data from northwestern Spain and that the Autunian has been incorporated as the highest substage of the Stephanian. The three substages involved in the present revision are shaded.

have shed their leaves in the lower part of the more sizeable tree trunks. W.A. DiMichele (personal communication 2013) makes a clear distinction between certain groups (including Omphalophloios, Polysporia, Paralycopodites $=$ Bergeria) with permanent leaves and others (including Diaphorodendron, Sigillaria) that may have shed their leaves during their lifetime. This distinction may be a valid one, and the evidence should be carefully examined for each particular case. We merely point out that the reconstructions showing large tree trunks devoid of leaves except for a small area in the top of the tree may have to be reconsidered in the light of taphonomic processes and preservational aspects. Coal ball material is not free from these considerations. However, we are not able to contribute to a solution of these problems because the material is subject to the usual preservational restrictions.

Another problem lies in the reconstruction of the shape and size of lycopsid trees. Virtually unbranched trees, such as Sigillaria and Omphalophloios, show a columnar shape - a broadly rounded stem apex and a stem diameter that remains more or less the same throughout. However, more conical shapes have also been observed for monopodial lycopsid trees. A different situation exists for lycopsid trees with profusely branched crowns, as in many lepidodendrids, Bothrodendron and Lepidophloios. How tall were these trees? Their mechanical strength may have been quite limited, and reconstructions of 30 to $35 \mathrm{~m}$ tall trees as for Diaphorodendron and Synchysidendron (see DiMichele and 
Bateman 1992) may be excessive, although these heights were inspired by the trunks up to $21.5 \mathrm{~m}$ long recorded by Wnuk (1985). The tree trunks figured by Wnuk show lateral branches produced by anisotomous forking. A similar structure is also suggested by the holotype of Lepidodendron dichotomum (refigured as Lepidodendron mannebachense by Opluštil 2010, fig. 5). Wnuk (1985) postulated that trees up to 40 to $45 \mathrm{~m}$ tall might have been present. Several different kinds of branching may have occurred, including the strictly dichotomous branching of the terminal parts of profusely branched Lepidodendron trees, as depicted in the reconstruction by Hirmer (1927, fig. 200). Recent evidence has revealed the presence of deciduous lateral branches in Synchysidendron (DiMichele et al. 2013) and perhaps in the Diaphorodendraceae in general, showing a richness of variety in lycopsid branching systems that have not always been acknowledged.

The constitution of lycopsid forests is another issue. Wnuk (1985) assumed the intermingling of different kinds of lycopsid tree. Indeed, he speculated on different canopy heights for forests containing different well-branched lycopsid trees. On the other hand, DiMichele and DeMaris (1987) found that a lycopsid forest as represented by standing and fallen tree trunks belonging, most likely, to a single species, Lepidodendron hickii, and occurring in roof shales of the Herrin ( $n^{\circ} 6$ ) coal seam in Illinois, apparently represented a monospecific association of nearly even-aged individuals. Monospecific stands may reflect an ecological dependence. The nature of the geological record plays an important role. Wnuk (1985) investigated an assemblage of drifted plant remains of diverse provenance. The assumption that all these plants lived in close proximity thus cannot be taken for granted. An assemblage of in-situ tree stumps providing contradictory evidence was recorded by DiMichele and DeMaris (1987). Similarly, Wagner and Diez (2007) and Wagner et al. (2012) described a large sandstone surface with the imprints of Sigillaria-tree bases at a lower Cantabrian locality in northwestern Spain that shows the colonization of a single kind of tree with two successive generations. An adjacent forest of a woody tree (Cordaites) at the same locality shows a separate development of trees with little intermingling at the border between the different stands. It is possible that the absence of the remains of smaller plants (undergrowth, lianas) at this locality may have been the result of catastrophic flooding, removing part of the floral association; but this is conjectural. In contrast, Opluštil et al. (2009) recorded a considerable diversity of floral elements in volcanic-ash deposits associated with the Radnice coals of Bolsovian age in the Czech Republic. They distinguished canopy, understorey, lianas and ground cover/ climbers. Although volcanic-ash fall guarantees instant burial, it is not clear to what extent these assemblages were in situ and not subjected to transport and intermingling prior to burial. The data presented by DiMichele and DeMaris
(1987) and Wagner et al. (2012) suggest that separate stands of trees were subjected to different environmental conditions. Ecological control on the presence of different kinds of arborescent lycopsids is also suggested by the link between Omphalophloios and brackish conditions (Wagner et al. 2003).

In-situ lycopsid trees have been recorded commonly (DiMichele and Falcon-Lang 2011), although perhaps not as commonly as might be expected in view of the frequent occurrence of casts of standing trees in cliff faces (e.g., Lyell and Dawson 1853; Scott and Calder 1994; Calder et al. 1996), quarries, and opencast sites. In every case it appears that only one kind of tree is represented in such cross-sections of fossil forests. Spectacular examples include the 7-m-tall Sigillaria trees found standing upright in sandstones overlying the Angelika and Sonnenschein coal seams in Westphalian A (Langsettian) strata of the Ruhr District, western Germany (Klusemann and Teichmüller 1954; Teichmüller 1955, Abb. 11). These well-figured columnar tree trunks, 3 to $5 \mathrm{~m}$ apart, show that the periderm cylinder may have allowed the remains to stay upright for the time necessary to deposit the sand now preserved as $7 \mathrm{~m}$ of bedded sandstones. This is quite a feat, requiring virtually instant sedimentation. Teichmüller's figure suggests that a single generation of trees, presumably all of the same kind, was represented. Upright tree trunks, particularly those attributed to Sigillaria, are quite common in the geological record. However, although records of lycopsid forests in twodimensional cliff and quarry faces are relatively common, records of stands of trunks in three-dimensions are rare. Observation of such stands requires either consecutive phases of two-dimensional outcrop in quarries and/or coal mines and the opportunity to follow the workings (e.g., DiMichele et al. 1996), or a different kind of preservation.

In the present paper only arborescent lycopsids of early Westphalian (middle Pennsylvanian) age are described from specimens preserved as adpressions. Thus we include not only classic genera like Lepidodendron, Lepidophloios and Sigillaria, but also some less-often-recorded taxa such as Bergeria (= Ulodendron sensu Thomas), Diaphorodendron and Omphalophloios. The uncommon but widespread genus Bothrodendron is an arborescent lycopsid not recorded from Canada (possibly due to limited collecting rather than absence). All of the genera included here are based on stem remains (including branches in genera that had repeatedly branched crowns or produced deciduous lateral branch systems). Where strobili have been found in connection or association, these are noted, as are parts of strobili (sporophylls) known to belong to named taxa. Lycopsid leaves are normally found detached, but where they are occasionally part of a branching system they are also mentioned. 


\section{REPOSITORY OF SPECIMENS, LOCALITY AND CATALOGUE NUMBERS}

Most of the specimens revised in the present paper are in the collections of the Geological Survey of Canada, Ottawa (catalogue numbers preceded by GSC). More complete information about localities is provided in the memoirs published by Bell (1938, pp. 108-115; 1940, pp. 133-139; 1944, p. 111-118; 1962, pp. 63-64). Three additional specimens have been studied from the Donald Reid collection (DRC), Joggins Fossil Centre, Joggins, Nova Scotia. A taxon list is provided in the Appendix.

Note that we do not cover lycopsids from the Fern Ledges locality of New Brunswick. Stopes (1914, p. 124) commented on "the extraordinary scarcity of both Sigillaria and Lepidodendron" at this locality. This scarcity is undoubtedly due to depositional circumstances. Although rooted vegetation has been reported from Fern Ledges by Falcon-Lang and Miller (2007), the evidence is unconvincing. All plant-bearing strata in the Fern Ledges section show drifted remains, including a high proportion of comminuted plant debris, and it is likely that shallow marine facies are represented. This would largely explain the absence of lycopsid tree fragments there. The records of Lepidodendron sp. and Sigillaria sp. by Stopes (1914) are all questionable.

\section{SYSTEMATICS}

In this section, partial synonymy lists are provided with special emphasis on types and illustrated records from North America. All synonyms (old and new) accepted by the present authors are included. European illustrations and/or specimens in the possession of the present writers are only cited where they provide a better understanding of the taxa involved. The system of annotations follows that of Cleal et al. $\left(1996-\right.$ simplified/modified): ${ }^{*}=$ protologue; $\mathbb{\S}$ $=$ first publication of currently accepted combination; $\mathrm{T}=$ other illustrations of the type specimen(s); ? = reference to doubtful specimens due to poor illustration or preservation; $\mathrm{p}$ (pars) $=$ only part of the published specimens belong to the species; $\mathrm{v}($ vide $)=$ specimen $(\mathrm{s})$ that the authors have seen; $\mathrm{k}=$ reference that includes cuticular evidence.

Descriptions and/or comparisons and remarks on published specimens are given as well as the stratigraphic and geographic distribution of taxa and their occurrence in Canada and the United States.

\author{
Class Lycopsida \\ Order Lepidodendrales \\ Family Lepidodendraceae
}

Genus Lepidodendron Sternberg 1820

TYPE. Lepidodendron aculeatum Sternberg 1820

GENERIC CHARACTERIZATION. Lepidodendron is one of the most cited and figured Carboniferous genera of arborescent lycopsid stem remains. It is characterized by vertically elongate, rhomboidal to fusiform leaf cushions, generally without leaves. Leaf scars are situated in the upper half of the cushion. Within the leaf scar are three foliar markings, a central one corresponding to the vascular bundle and two lateral parichnos strands. A ligule pit is present above the leaf scar and two infrafoliar parichnos markings occur below the scar, i.e., on the cushion surface. Stems of Lepidodendron with attached leaves have been figured only rarely (e.g., Kosanke 1979, figs. 1, 4; Leary and Thomas 1989, figs. 5-8; Josten and Amerom 2003, Taf. 26, fig. 1; Opluštil 2010, figs. 1A, 2A, 4A,B; and Wagner and Álvarez-Vázquez 2010, pl. XI, fig. 1).

Lepidodendron was discussed by DiMichele (1983) based on the anatomically preserved species Lepidodendron hickii, which he regarded as equivalent to the adpression species Lepidodendron aculeatum. DiMichele $(1983,1985)$ noted the rather indiscriminate use of the name Lepidodendron; he thus endeavoured to distinguish several more closely circumscribed genera based primarily on anatomical detail, as found in permineralized remains. Although anatomical detail is reflected only to a limited extent in compressions/ impressions of the stem surface, certain characters permit correlation between the different preservational modes.

Relatively few of the 414 species of Lepidodendron named in the Fossilium Catalogus (Jongmans 1929, 1936; Jongmans and Dijkstra 1969; Dijkstra and Amerom 1991, 1994) should remain in Lepidodendron sensu stricto. The large number of named taxa also includes several synonyms. Rather surprisingly, the oft-quoted Lepidodendron aculeatum, generally regarded as synonymous with Lepidodendron obovatum, is not as common as the published records suggest.

The following genera have been separated from Lepidodendron in recent decades (see reviews by DiMichele 1980; Bateman and DiMichele 1991; Bateman et al. 1992; and Phillips and DiMichele 1992): Anabathra /Paralycopodites, Diaphorodendron, Synchysidendron, and Hizemodendron.

In the present paper, three little-known species are recorded here as Lepidodendron sensu lato, acknowledging that they do not belong in Lepidodendron, but recognizing that an exact attribution is not possible at present. 


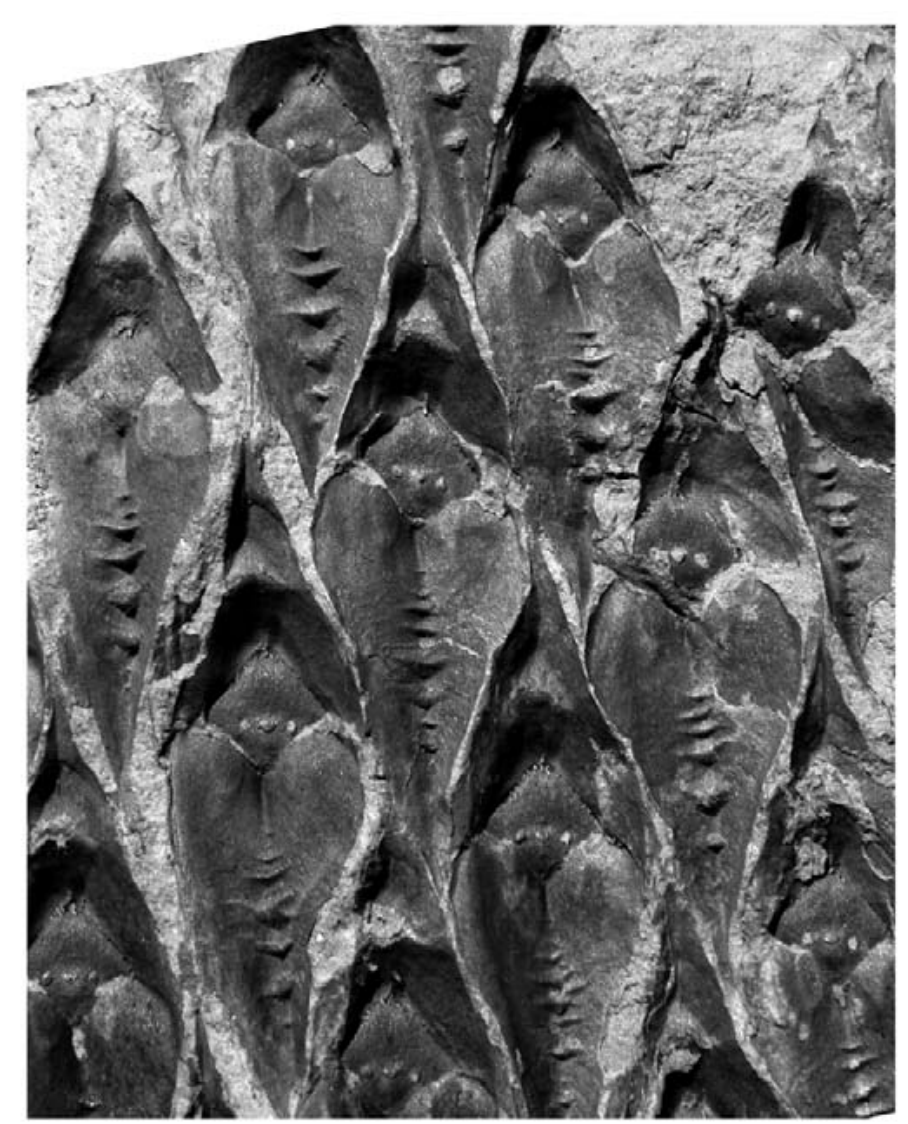

Figure 2. Lepidodendron aculeatum ( $\mathrm{x}$ 2). Origin: southwestern Spain, Peñarroya-Belmez-Espiel coalfield, borehole S-167 (locality 5651). Repository: Centro Paleobotánico, Real Jardín Botánico de Córdoba.

\section{Lepidodendron aculeatum Sternberg 1820}

(Fig. 2)

* 1820 Lepidodendron aculeatum Sternberg, p. 20, Taf. VI, fig. 2; Taf. VIII, figs. 1Ba, b.

* 1820 Lepidodendron obovatum Sternberg, p. 20, Taf. VI, fig. 1; Taf. VIII, figs. 1Aa,.b.

* 1820 Lepidodendron crenatum Sternberg, p. 21, Taf. VIII, figs. 2Ba, b (acc. to Kidston 1886).

* 1822 Sagenaria coelata Brongniart, p. 209, pl. I, fig. 6 (acc. to Kidston 1886).

* 1838 Sagenaria caudata Presl in Sternberg, p. 178, Taf. LXVIII, fig. 7 (acc. to Lesquereux 1880).

* 1858 Lepidodendron conicum Lesquereux, p. 874, pl. XV, fig. 3 (acc. to Kidston 1893, albeit with doubt).

* 1858 Lepidodendron giganteum Lesquereux, p. 874, pl. XV, fig. 2 (acc. to Fairchild 1877).

* 1858 Lepidodendron modulatum Lesquereux, p. 874, pl. XV, fig. 1 (acc. to Fairchild 1877).

* 1858 Lepidodendron obtusum Lesquereux (non Sauveur), p. 875 , pl. XVI, fig. 6 (acc. to Fairchild 1877).

* 1860 Lepidodendron venustum Wood, pp. 239-240, pl. 5 , fig. 2 (included by Lesquereux 1880 in Lepidodendron obtusum).

* 1860 Lepidodendron mekiston, Wood, p. 239, pl. 5, fig. 3 (acc. to Wood 1869, p. 345).

* 1860 Lepidodendron Lesquereuxi Wood, p. 240, pl. 5, fig. 4 (acc. to Lesquereux 1880).

* 1860 Lepidodendron Bordae Wood, p. 240, pl. 6, fig. 3 (included by Wood 1869 in Lepidodendron obovatum, regarded as a synonym of Lepidodendron aculeatum).

* 1860 Lepidodendron magnum Wood, pl. 6, fig. 4 (acc. to Fischer 1905a, who included this species in Lepidodendron obovatum, as a synonym of Lepidodendron aculeatum).

* 1869 Lepidodendron uraeum Wood, pp. 343-344, pl. IX, fig. 5 (acc. to Lesquereux 1880).

1879-80 Lepidodendron aculeatum, Lesquereux, p. 371, pl. LXIV, fig. 1.

1934 Lepidodendron aculeatum, Arnold, p. 188, pl. VI, fig. 6.

1934 Lepidodendron obovatum, Arnold, p. 189, pl. VI, fig. 1.

v 1944 Lepidodendron aculeatum?, Bell, p. 90, pl. XLIX, fig. 5 (decorticated); pl. L, fig. 3.

1949 Lepidodendron obovatum, Arnold, pp. 161-162, pl. III, fig. 1 (decorticated), fig. 2.

1949 Lepidodendron modulatum, Arnold, pp. 170-171, pl. III, fig. 3.

1957 Lepidodendron aculeatum, Janssen, pp. 38-39, fig. 15.

1959 Lepidodendron aculeatum, Canright, p. 28, pl. 1, fig. 6.

1959 Lepidodendron obovatum, Canright, p. 20, 28, pl. 1, fig. 2.

1959 Lepidodendron modulatum, Canright, p. 20, 28, pl. 1 , fig. 3.

1962 Lepidodendron sp., Gillespie and Clendening, p. 129 , pl. 3, fig. 5.

1963 Lepidodendron modulatum, Wood, p. 35, pl. 1, fig. 6 (same as Canright 1959, pl. 1, fig. 3).

1963 Lepidodendron obovatum, Wood, pp. 35-36, pl. 1, fig. 7.

? 1963 Lepidodendron aculeatum, Wood, pp. 33-34, pl. 1, fig. 2.

T 1963 Lepidodendron aculeatum, Němejc, Tab. XII, fig. 4; Tab. XIII, fig. 3 (partial illustration of the holotype).

1966 Lepidodendron, Gillespie et al., p. 24, 52, pl. 6, fig. 5.

1967 Lepidodendron aculeatum, Tidwell, p. 19, pl. 1, fig. 5 (poorly preserved).

1969 Lepidodendron aculeatum, Darrah, p. 181, pl. 30, fig. 1.

T k 1970 Lepidodendron aculeatum, Thomas, p. 146, pl. 
29, fig. 1 (photograph of the specimen illustrated in Sternberg 1820, Taf. VI, fig. 2), fig. 2 (Lepidodendron obovatum Sternberg 1820, Taf. VI, fig. 1a), fig. 3 (Sagenaria rugosa Presl in Sternberg 1838, Taf. LXVIII, fig. 4), fig. 4 (Sagenaria caudata Presl in Sternberg 1838, Taf. LXVIII, fig. 7); pl. 30, fig. 1 (Lepidodendron crenatum Sternberg 1820, Taf. VIII, fig. 2B), fig. 5; pl. 31, figs. 1-3; text-figs. 2A-F, 3A-E.

1974 Lepidodendron lanceolatum sensu Noé, Tidwell et al., pp. 126-128, pl. 4, fig. 2.

1978 Lepidodendron aculeatum, Gillespie et al., p. 46, 52, 53, pl. 11, fig. 1 (same as Gillespie and Clendening 1962), fig. 2 (drawing).

1978 Lepidodendron cf. wortheni, Gillespie et al., p. 46, 52,53 , pl. 11, fig. 7 .

1979 Lepidodendron obovatum var. grandifolium Kosanke, p. 431, fig. 1, fig. 2 (drawing), fig. 3 (leaves), fig. 4.

1980 Lepidodendron aculeatum, Zodrow and McCandlish, p. 79, pl. 114, fig. 2; pl. 115, fig. 1, fig. 2 (poorly figured).

p 1981 Lepidodendron aculeatum, DiMichele and Dolph, pl. 2, fig. 13; non pl. 2, fig. 14 (= Lepidodendron bellii as introduced in the present paper).

1982 Lepidodendron aculeatum, Oleksyshyn, pp. 11-13, fig. 7A (poorly figured).

p 1984 Lepidodendron aculeatum, Jennings, p. 304, 307, pl. 3, fig. 1; non pl. 1 fig. 4 (decorticated resembles Lepidodendron veltheimii).

1985 Lepidodendron cf. wortheni, Gillespie and Crawford, p. 252, pl. II, fig. 2.

1989 Lepidodendron aculeatum, Leary and Thomas, figs. $3,4,6,8$.

1989 Lepidodendron aculeatum, Gillespie et al., p. 5, pl. 1, fig. 11.

1992 Lepidodendron aculeatum, Tidwell et al., p. 1014, figs. 2.2, 2.3.

T 1992 Lepidodendron aculeatum, Kvaček and Kvaček, Tab. I, fig. 1 (part of Sternberg's 1820 holotype).

1995 Lepidodendron aculeatum, Willard et al., p. 81, 82, fig. $8 \mathrm{E}$.

1996 Lepidodendron cf. aculeatum, Calder et al., p. 292, fig. 8a.

p 1996 Lepidodendron aculeatum, Cross et al., p. 402, fig. 23-5.2; non p. 401, fig. 23-4.5 (poorly figured and difficult to assign specifically, but definitely not Lepidodendron aculeatum).

T 1997 Lepidodendron aculeatum, Kvaček and Straková, p. 27, pl. 2, fig. 1 (photograph of holotype).

1997 Lepidodendron obovatum, Kvaček and Straková, p. 112, pl. 39, fig. 5 (photograph of holotype).

1997 Lepidodendron crenatum, Kvaček and Straková, p. 57, pl. 17, fig. 1 (photograph of holotype).
1997 Sagenaria caudata, Kvaček and Straková, p. 47, pl. 10, fig. 6 (photograph of holotype).

2005 Lepidodendron aculeatum, Dilcher et al., p. 155, figs. 1.1, 1.2.

2005 Lepidodendron aculeatum, Dilcher and Lott, pl. 117, figs. 2, 4, fig. 3 (same as Dilcher et al. 2005, fig. $1.1)$.

T 2005 Lepidodendron aculeatum, Cleal et al., p. 46, fig. 4 (lower) (copy of Sternberg's figure).

2005 Lepidodendron aculeatum, Cleal et al., p. 46, fig. 4 (upper) (copy of Lepidodendron obovatum holotype).

2006 Lepidodendron aculeatum, Calder et al., p. 180, 182, figs. 10B, C.

p 2006 Lepidodendron aculeatum, Wittry, pp. 104-105, figs. 1, 2 (same as Lequereux's Lepidodendron modulatum 1879, pl. XLIV, figs. 13, 14), fig. 3, figs. 4-7 (drawings after Thomas 1970); non fig. 8 (= Diaphorodendron decurtatum).

p 2006 Lepidodendron rimosum, Wittry, fig. 3; non p. 107, fig. 1 (copy of Lepidodendron simplex Lesquereux 1866, a synonym of "Lepidodendron" rimosum); non fig. 2 (copy of Lesquereux 1879, pl. LXIV, fig. 11).

p 2009 Lepidodendron aculeatum, Lucas et al., p. 237, 239, 240, figs. 3C, 5A-5D; non figs. 5E, 5F (= Lepidodendron dichotomum).

v 2010 Lepidodendron aculeatum, Wagner and Álvarez-Vázquez, p. 257, 262, 264, 266, 270, 273, pl. XI, fig. 1 (specimen with attached leaves).

v 2012 Lepidodendron aculeatum, Álvarez-Vázquez and Wagner, p. 1234, fig. 3 (same specimen as figured here as Fig. 2).

p 2013 Lepidodendron aculeatum, Lucas et al., p. 45, fig. 5.2.; non fig. 5.1. (= Lepidodendron bellii).

Excludenda:

1873 Lepidodendron aculeatum, Dawson, p. 24, pl. V, figs. 37, 37a (decorticated and indeterminable specifically); p. 32, pl. IX, fig. 75 (= "Lepidodendron" feistmantelii); pl. IX, figs. $75 a-75 c$ (diagrammatic drawings that cannot be judged properly).

1949 Lepidodendron aculeatum, Arnold, pp. 160-161, pl. II, figs. 1, 3, 4 (possibly referable to Bergeria dilatata).

1958 Lepidodendron aculeatum, Langford, p. 65, fig. 101 (same specimen as in p. 23, fig. 14) (to be compared with "Lepidodendron" fusiforme).

1966 Lepidodendron aculeatum, Bell, p. 26, pl. XII, fig. 2 (Lepidodendron bellii - holotype).

1968 Lepidodendron aculeatum, Abbott, p. 7, pl. 12, fig. 8 (very diagrammatic drawing that is difficult to judge but unlikely to be Lepidodendron aculeatum).

1974 Lepidodendron aculeatum, Jennings, p. 460, pl. 1, fig. 1 (to be compared with Lepidodendron bellii). 
1974 Lepidodendron aculeatum, Tidwell et al., p. 121, pl. 1, fig. 3 (to be compared with "Lepidodendron" fusiforme).

1982 Lepidodendron aculeatum, DiMichele in Eggert and Phillips, p. 20, pl. 2, fig. B (= Diaphorodendron decurtatum).

1985 Lepidodendron cf. aculeatum, Gastaldo, p. 292, pl. 3 , fig. A (difficult to judge from illustration, but clearly not Lepidodendron aculeatum; resembles Diaphorodendron decurtatum).

1987 Lepidodendron aculeatum, DiMichele and DeMaris, p. 149, fig. 3 (decorticated similar to specimen figured by Bell 1944), figs. 4 , 5 (= "Lepidodendron" jaraczewskii acc. to DiMichele personal communication 2013).

REMARKS. The list above includes all names generally recognized as synonyms of the widely reported Lepidodendron aculeatum, as well as all figured North American remains. The holotypes of Lepidodendron aculeatum (Sternberg 1820, Taf. VI, fig. 2) and Lepidodendron obovatum (Sternberg 1820, Taf. VI, fig. 1) both originated from the Radnice Member (Bolsovian), Kladno Formation, Bohemia, Czech Republic. Although most authors accept that these two species are synonymous, there has been no agreement on a preferred specific epithet. Andrews (1955, p. 178) mentioned that Lepidodendron dichotomum was the first species of Lepidodendron figured by Sternberg, implying that this would be the type species. However, he suggested that Lepidodendron obovatum might be a better type. On the other hand, Chaloner and Boureau (in Boureau 1967) pointed out that the problems surrounding the use of Lepidodendron obovatum made this species unsuitable. They regarded Lepidodendron aculeatum as more appropriate. We concur considering that Lepidodendron aculeatum has been used in a consistent manner, whereas the use of Lepidodendron obovatum has been more controversial. [We acknowledge that by admitting the synonymy of Lepidodendron aculeatum with Lepidodendron obovatum but not following Andrews' choice of the latter as the correct name, we are contravening rules of priority (ICBN Article 11.5; http:// www.iapt-taxon.org/nomen/main.php?page=art11).]

From the Cumberland Basin, Bell (1944) figured as Lepidodendron aculeatum? two specimens representing quite substantial tree trunks. One of these specimens (Bell 1944, pl. XLIX, fig. 5) was available for us to study. Unfortunately, this is the least well preserved. It is the cast of a decorticated specimen that, although it shows the outline of the leaf cushions reasonably well, provides little detail of the leaf scar. It lacks a leaf trace and shows only vague parichnos markings. Only one leaf scar is clearly visible, at about one third the height of the elongate rhombic leaf cushion. Although preservation is poor, the size and shape of the keeled leaf cushions and the position of the relatively small leaf scar suggest that the Lepidodendron aculeatum determination by Bell is correct. The second specimen figured by Bell (1944, pl. L, fig. 3), although also poorly preserved, even more clearly belongs to this species.

In order to facilitate comparison with Lepidodendron bellii (= Lepidodendron obovatum sensu Presl in Sternberg 1838, non Sternberg 1820), we figure a well-preserved specimen of Lepidodendron aculeatum from most Langsettian strata in the Peñarroya Basin, southwestern Spain (Fig. 2).

COMPARISONS. Leaf cushions of Lepidodendron bellii are rhomboidal, with a marked horizontal asymmetry. The upper and lower ends of leaf cushions in this species are only slightly inflected in opposite directions, whereas in Lepidodendron aculeatum the cushions are fusiform, symmetrical and with acuminate apex and base that are distinctly inflected in opposite directions. The leaf scar is rhomboidal in both species, but is located in the upper third in Lepidodendron bellii, and a little above the middle in Lepidodendron aculeatum. Also, the length/breadth ratio of the leaf cushion is 3-4 in Lepidodendron aculeatum and up to 2.5 in Lepidodendron bellii. However, this ratio might vary depending on the position on the stem and is thus an unreliable character for species distinction.

STRATIGRAPHIC AND GEOGRAPHIC DISTRIBUTION. This is one of the most commonly (albeit not always correctly) cited species of Pennsylvanian Lepidodendraceae, with a range that includes most of the Namurian (from Chokierian upwards) as well as the entire Westphalian, where it is most frequent.

OCCURRENCE IN THE MARITIME PROVINCES, CANADA. CUMBERLAND BASIN (NOVA SCOTIA): Bell (1944): locality 1983 (GSC 8562 - decorticated); Springhill (GSC 8558). Calder et al. (2006). SYDNEY BASIN (NOVA SCOTIA): Zodrow and McCandlish (1980). Calder et al. (1996).

OCCURRENCE IN THE UNITED STATES. ALABAMA: Gillespie and Rheams (1985, unfigured), Dilcher and Lott (2005), Dilcher et al. (2005). ARIzONA: Tidwell et al. (1992). GEORGIA: Gillespie and Crawford (1985), Gillespie et al. (1989). ILLINOIS: Lesquereux (1879-1880), Janssen (1957), Langford (1958), Darrah (1969), Jennings (1984), Leary and Thomas (1989), Wittry (2006). INDIANA: Canright (1959), Wood (1963), DiMichele and Dolph (1981), Willard et al. (1995). MICHIGAN: Arnold (1934, 1949). NEW MEXICO: Lucas et al. (2009), Lucas et al. (2013). OHio: Cross et al. (1996). PENNSYlVANIA: Wood (1860, 1869), Lesquereux (1858), Lesquereux (1879-1880), Oleksyshyn (1982). RHODE ISLAND: Lesquereux (1879-1880). UTAH: Tidwell (1967), Tidwell et al. (1974). WEST VIRGINIA: Gillespie and Clendening (1962), Gillespie et al. (1966), Gillespie et al. (1978); Kosanke (1979). 
Lepidodendron bellii sp. nov.

(Figs. 3a-b)

1838 Sagenaria obovata Presl in Sternberg, p. 178, Taf. LXVIII, fig. 6.

?* 1848 Lepidodendron costoe Sauveur, pl. LXI, fig. 1.

?* 1848 Lepidodendron obtusum Sauveur, pl. LXI, fig. 2.

?* 1858 Lepidodendron carinatum Lesquereux

(non Brongniart), p. 875, pl. XV, fig. 4 (see

Jongmans, 1929) (homonym of

Lepidodendron carinatum Brongniart).

?* 1858 Lepidodendron clypeatum Lesquereux, p. 875, pl. XV, fig. 5; pl. XVI, fig. 7 (decorticated).

?* 1858 Lepidodendron vestitum Lesquereux, p. 874, pl. XVI, fig. 3.

p 1879-80 Lepidodendron clypeatum, Lesquereux, p. 380, pl. LXIV, figs. 16-16b; non pl. LXIV, figs. 17, 18 (drawing of leaf cushion).

p 1937 Lepidodendron obovatum, Jongmans, p. 404, pl. 24, fig. 61 ; non p. 403 , pl. 23 , fig. 55

(= Bergeria dilatata).

? 1944 Lepidodendron obovatum?, Bell, p. 89, pl. LII (poorly preserved).

? 1957 Lepidodendron obovatum, Janssen, p. 39, 41, fig. 16 (poorly preserved).

? 1963 Lepidodendron vestitum, Wood, p. 36, pl. 1, fig. 9 (leaf cushions laterally squashed).

1963 Lepidodendron obovatum, Němejc, Tab. XII, fig. 3 (photograph of part of the specimen figured by Presl in Sternberg 1838 as Sagenaria obovata).

p 1964 Lepidodendron obovatum, Crookall, pp. 239-242, pl. LX, fig. 4; text-fig. 77B (drawing of leaf cushion); non pl. LX, fig. 3 (to be compared with Diaphorodendron decurtatum); non text-fig. 78 (copy of Hirmer's 1927 reconstruction of the tree).

* 1966 Lepidodendron aculeatum, Bell, p. 26, pl. XII, fig. 2 (reproduced partially herein as holotype of Lepidodendron bellii).

? 1967 Lepidodendron obovatum, Tidwell, p. 19, pl. 2, fig. 6 (difficult to judge from illustration; presence of leaf scars unclear).

p k 1970 Lepidodendron mannabachense (sic), Thomas, pl. 30, fig. 3 (photograph of the specimen figured as a drawing of Sagenaria obovata); non pp. 157-159, pl. 30, fig. 4 (same specimen as Lepidodendron mannebachense Presl in Sternberg 1838, Taf. LXVIII, fig. 2); pl. 32; pl. 34, figs. 1, 2, 7, 8; text-figs. 7, 8.

1974 Lepidodendron aculeatum, Jennings, p. 460, pl. 1, fig. 1.

? $\quad 1974$ Lepidodendron mannabachense (sic), Tidwell et al., p. 123 (as Lepidodendron obovatum in Tidwell 1967).

1978 Lepidodendron obovatum, Gillespie et al., p. 52, pl. 11, figs. 3 (drawing), 5; pl. 11, fig. 6 .

p 1981 Lepidodendron aculeatum, DiMichele and Dolph, pl. 2, fig. 14; non pl. 2, fig. 13 (= Lepidodendron aculeatum).

1985 Lepidodendron obovatum, Gillespie and Rheams, p. 194, 196, pl. III, fig. 6.

1989 Lepidodendron obovatum, Gillespie et al., p. 5, 6, pl. 2, fig. 5.

1996 Lepidodendron cf. obovatum, Calder et al., p. 292, fig. 8 b.

1997 Sagenaria obovata, Kvaček and Straková, p. 163, pl. 64, fig. 2 (photograph of specimen figured as a drawing by Presl in Sternberg 1838, Taf. LVIII, fig. 6).

2005 Lepidodendron obovatum, Dilcher et al., pp. 155156, figs. 1.3, 1.4.

2005 Lepidodendron obovatum, Dilcher and Lott, pl. 117, fig. 1 (same as Dilcher et al. 2005, fig. 1.3); pl. 118, fig. 4.

v 2010 Lepidodendron mannebachense, Wagner and Álvarez-Vázquez, p. 257, 262, 266.

p 2013 Lepidodendron aculeatum, Lucas et al., p. 45, fig. 5.1.

HOLOTYPE. Pl. XII, fig. 2 of Bell 1966 (partially copied here as Fig. 3); Springhill Mines, Cumberland Basin, Nova Scotia.

DERIVATION OF NAME. After Walter A. Bell, in recognition of his fundamental contributions to Carboniferous paleobotany in Canada.

DIAGNOSIS. Leaf cushions rhomboidal, higher than wide, with rounded lateral angles and acute base and apex; upper part of area above the leaf scar relatively small, and that below large and with a keel. Leaf scars rhomboidal and situated high on the cushion. Infrafoliar parichnos small, vertically elongate.

DESCRIPTION (based on the specimen figured by Bell 1966). Leaf cushions rhomboidal, higher than wide, horizontally asymmetrical, with rounded lateral angles and an acute base and apex that are very slightly inflected in opposite directions. Dimensions: $28-30 \mathrm{~mm}$ long and $11-12 \mathrm{~mm}$ broad; ratio $=2.5$. Leaf scars rhomboidal, placed in the upper third of the cushion and occupying less than one-third of cushion width; rhomboidal, with rounded margins and three small, rounded cicatricules arranged in a line. Dimensions: 3-4 mm long and $4-5 \mathrm{~mm}$ broad; ratio = 0.7-0.8. Infrafoliar parichnos vertically elongate, elliptical, small, but distinct. Keel well-marked below the leaf scar, with short (less than $1 \mathrm{~mm}$ ) transverse markings. Upper part of the field small, with a short, poorly marked keel. 

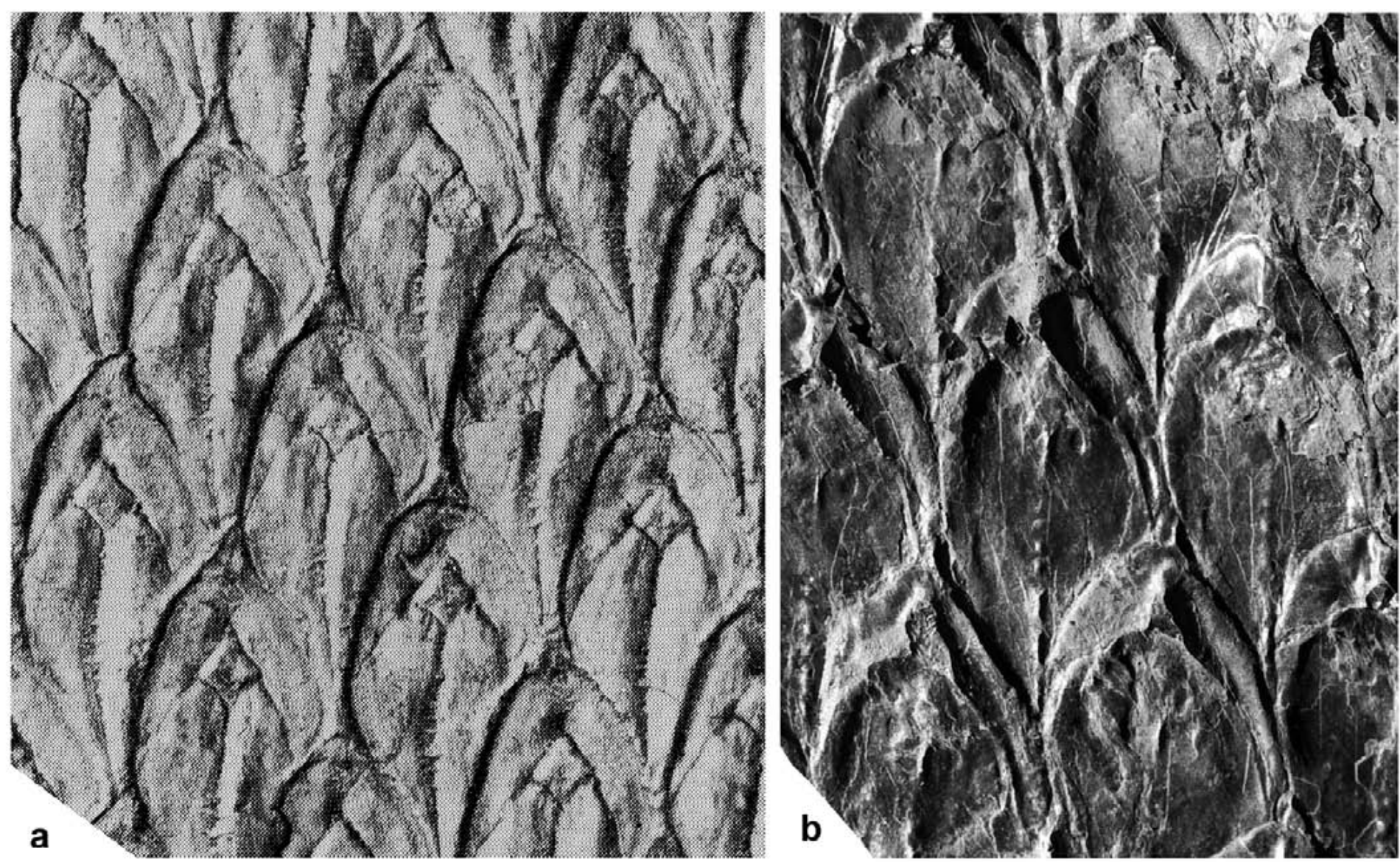

Figure 3. (a) Lepidodendron bellii (x 2). GSC 14937. Partial copy of the photograph published by Bell as Lepidodendron aculeatum (Bell 1966, pl. XII, fig. 2). Origin: Springhill, roof of unspecified coal seam. Repository: Geological Survey of Canada, Ottawa. (b) Lepidodendron bellii (x 2). Origin: southwestern Spain, Peñarroya-Belmez-Espiel coalfield, Rampa María (locality 5878). Repository: Centro Paleobotánico, Real Jardín Botánico de Córdoba.

REMARKS. Although the holotype of Lepidodendron obovatum (as photographed by Němejc 1963, Thomas 1970 and Kvaček and Straková 1997) is conspecific with Lepidodendron aculeatum, other specimens figured as Lepidodendron obovatum are not. Jongmans (1929, p. 225-244) provided the first exhaustive synonymy of Lepidodendron obovatum. Of subsequent work, most important is Nermejc's (1947, p. 53) opinion that the specimen figured as Sagenaria obovata by Presl (in Sternberg 1838, Taf. LXVIII, fig. 6), does not belong to Lepidodendron aculeatum. Presl's specimen was refigured by Thomas (1970, pl. 30, fig. 3 - erroneously cited in his plate caption as Presl in Sternberg 1838, pl. LXVIII, fig. 2), who assigned it, incorrectly, to Lepidodendron mannebachense. The holotype of Lepidodendron mannebachense (as photographed by Thomas 1970, pl. 30, fig. 4 and Kvaček and Straková 1997, pl. 33, fig. 6) possesses almost isodiametric leaf cushions, shown by Thomas (1970, fig. 7A) to lack infrafoliar parichnos. This specimen, originating from the Lower Rotliegend (Autunian) of Manebach in Thuringia (Germany), is different from the other remains attributed to
Lepidodendron mannebachense by Thomas (1970). The latter, of Westphalian age, are characterized by more elongate leaf cushions showing infrafoliar parichnos.

The magnificent specimen from the roof of an unspecified coal seam at Springhill, Nova Scotia, figured by Bell (1966, pl. XII, fig. 2) as Lepidodendron aculeatum is regarded as conspecific with the specimen figured as Lepidodendron obovatum by Presl in Sternberg (1838, pl. LXVIII, fig. 6), and which we regard as different. The specimen from Springhill is here selected as the holotype of Lepidodendron bellii.

The possible synonyms in the list above refer to specimens (holotypes) that are poorly figured and which require revision of material not available to us.

STRATIGRAPHIC AND GEOGRAPHIC DISTRIBUTION. Presl's specimen is from the Bolsovian of the Radnice Member, Kladno Formation, Bohemia. Crookall (1964) recorded this species (as Lepidodendron obovatum) throughout the Westphalian. 
OCCURRENCE IN THE MARITIME PROVINCES, CANADA. CUMBERLAND BASIN (NOVA SCOTIA): Bell (1944): Springhill (GSC 5813 - decorticated). Bell (1966): Springhill (GSC 14937 - holotype). SYDNEY BASIN (NOvA sCOTIA): Calder et al. (1996).

OCCURRENCE IN THE UNITED STATES. ALABAMA: Lesquereux (1879-1880), Gillespie and Rheams (1985), Dilcher and Lott (2005), Dilcher et al. (2005). GEORGIA: Gillespie et al. (1989). ILLINOIs: Lesquereux (1879-1880), Janssen (1957), Jennings (1974), Wittry (2006). INDIANA: Wood (1963), DiMichele and Dolph (1981). NEW MEXICO: Lucas et al. (2013). PENNSYLVANIA: Lesquereux (1879-1880). UTAH: Tidwell (1967), Tidwell et al. (1974). WEST VIRGINA: Jongmans (1937); Gillespie et al. (1978).

\section{“Lepidodendron" feistmantelii Zalessky 1904} (Figs. 4a-b)

p 1873 Lepidodendron aculeatum, Dawson, p. 32, pl. IX, fig. 75; pl. IX, fig. 75b (?); non pl. IX, figs. 75 a (drawing of a decorticated specimen that seems indeterminable); non pl. IX, fig. 75c (drawing of leaf scar with presumed ligule pit (?) that does not seem to belong to "Lepidodendron" feistmantelii); non p. 24, pl. V, figs. 37, 37a (rough drawings of a lepidodendrid with characteristics different from "Lepidodendron" feistmantelii).

* 1904 Lepidodendron Feistmanteli Zalessky, pp. 20-21, 93, pl. IV, figs. 6, 10.

p 1904 Lepidodendron Veltheimi, Zalessky, pp. 21-23, 94, pl. IV, fig. 9; pl. VIII, fig. 8; non pl. IV, figs. 3-5 (to be compared with Lepidodendron jaraczewskii Zeiller); non pl. IV, fig. 12 (decorticated); non pl. IV, fig. 8 (decorticated).

1907 Lepidodendron Veltheimi, Zalessky, pp. 436-437, Tab. XXIII, fig. 13.

1913-14 Lepidodendron Jaraczewskii, Bureau, pp. 113115, pl. XL, figs. 1, 1A; pl. XXXIX, figs. 2, 2A (?), figs. 3, 3A (?).

vp 1944 Lepidodendron jaraczewskii, Bell, p. 89, pl. LI, fig. 2 (refigured here as Figs. 4a, b); non pl. LI, fig. 1 (= Omphalophloios anglicus; see Figs. 4c,d of the present paper).

k 1970 Lepidodendron feistmanteli, Thomas, p. 155, pl. 33, fig. 3; pl. 34, fig. 5 (cuticle); text-figs. 6A-E.

1994 Lepidodendron feistmantelii, Cleal and Thomas, $\mathrm{p}$. 63, pl. 4, fig. 5 (same as Thomas 1970, pl. 33, fig. 3); text-figs. 30C, 30D (same as Thomas 1970, textfigs. 6A, 6B).

Excludenda:

1974 Lepidodendron feistmanteli, Tidwell et al., p. 131, pl. 3, figs. 1, 5 (shows small, equidimensional leaf cushions with a distinct leaf scar; to be compared with Lepidodendron dichotomum).
DESCRIPTION. Leaf cushions smooth, only slightly raised, spirally arranged, and separated from one another by narrow grooves (c. $1 \mathrm{~mm}$ width); elongate rhomboidal, bilaterally symmetrical, with a very prominent keel (in the impression), present both above and below the leaf scar; upper and lower angles of cushions acute, with almost straight margins that are only very slightly inflected in opposite directions; lateral angles more rounded. Dimensions: $30-35 \mathrm{~mm}$ long and $11-13 \mathrm{~mm}$ broad, with the maximum breadth about the middle; length/breadth $\approx$ 2.7. Leaf scar situated a little above the middle of cushion, prominent, $3.5-4.5 \mathrm{~mm}$ broad, occupying one third of cushion width; its lateral angles prolonged into two wellmarked straight, horizontal lines reaching the cushion margin. Vascular bundle prints and infrafoliar parichnos lacking. Ligule scar present at $2-3 \mathrm{~mm}$ above the leaf scar.

REMARKS. Bell (1944) figured and described as Lepidodendron jaraczewskii two very different specimens. One of these (Bell 1944, pl. LI, fig. 1) may be attributed to Omphalophloios anglicus (see below). The other specimen (Bell 1944, pl. LI, fig. 2 - Figs. 4a-b of the present paper) shows leaf cushions with a prominent keel both above and below the leaf scar and strongly marked straight lines from the edges of the leaf scar to the cushion margin. Lepidodendron jaraczewskii also possesses rhomboidal, elongate leaf cushions, but keels are less prominent and the lateral lines from the leaf scars curve downwards to reach the cushion margin. This is quite different to the pattern observed in the specimen from Nova Scotia.

Thomas (1970) assigned both of Bell's specimens to Lepidodendron feistmantelii, an identification that we support only for one (Bell 1944, pl. LI, fig. 2 - Figs. 4a-b herein). Zalessky (1904, pl. IV, figs. 6, 10) based Lepidodendron feistmantelii on two specimens from the Donets Basin that show well-marked, rhomboidal, isodiametric, smooth leaf cushions with a marked keel and a centrally placed leaf scar. Zalessky (1904, pl. IV, fig. 9; pl. VIII, fig. 8) also figured two specimens under the name Lepidodendron veltheimii that show the same characters albeit with more elongate leaf cushions. This is regarded here as being within the intraspecific variation Zalessky (1904) considered Lepidodendron jaraczewskii, the specific name later used by Bell (1944), as conspecific with Lepidodendron veltheimii. However, the holotype of Lepidodendron veltheimii as photographed (upside down) by Kvaček and Straková (1997, pl. 54, fig. 4) has smaller leaf cushions with proportionately larger, transversally elongate leaf scars occupying most of the cushion width. Also, the arched lines that meet the cushion margin from the lateral sides of the leaf scar in Lepidodendron jaraczewskii are not present in Lepidodendron veltheimii.

STRATIGRAPHIC AND GEOGRAPHIC DISTRIBUTION. "Lepidodendron" feistmantelii is very rare. Zalessky's material is from two different horizons in the 

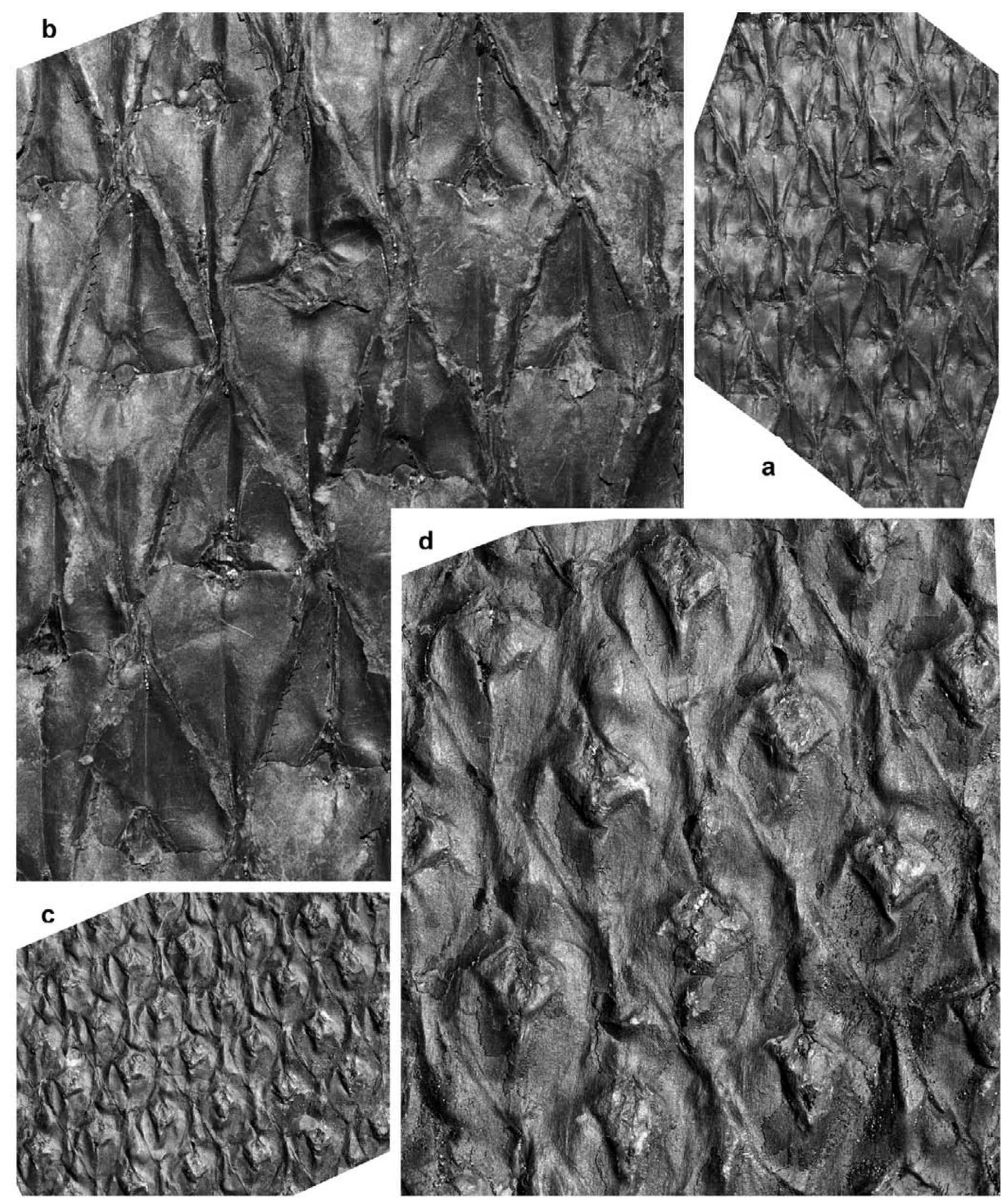

Figure 4. (a) "Lepidodendron" feistmantelii (x 1). GSC 8553. Specimen figured as Lepidodendron jaraczewskii by Bell (1944, pl. LI, fig. 2). Origin: Kemptown (locality 2995). (b) "Lepidodendron" feistmantelii. Enlargement (x 3 ) of part of the specimen in 4a. (c) Omphalophloios anglicus. GSC 8712. Specimen (x 1) figured as Lepidodendron jaraczewskii by Bell (1944, pl. LI, fig. 1). Origin: Springhill, roof of $n^{\circ} 1$ coal seam (locality 1337). (d) Omphalophloios anglicus. Enlargement (x 3 ) of part of the same specimen. Repository: Geological Survey of Canada, Ottawa. 
Upper Bashkirian of the Donets Basin $\left(\mathrm{C}_{2}{ }^{3}\right)$ and Middle Moscovian $\left(\mathrm{C}_{2}{ }^{6}\right)$. In Great Britain, the species ranges from Langsettian to lower Bolsovian (see Thomas 1970). Bureau's (1913) specimens come from the Namurian (Serpukhovian?) of Basse Loire, southern France.

OCCURRENCE IN THE MARITIME PROVINCES, CANADA. PICTOU COALFIELD (STELLARTON BASIN, NOvA SCOTIA): Bell (1944): locality 2995 (GSC 8553) (Bell 1944, p. 89 recorded the specimen from this locality as possibly originating from the Pictou Group).

"Lepidodendron" rimosum Sternberg 1820 (Figs. 5a-b)

* 1820 Lepidodendron rimosum Sternberg, Taf. X, fig. 1 .

* 1860 Lepidodendron dikrocheilus Wood, p. 239, pl. 6, fig. 1 (acc. to White 1899).

* 1866 Lepidodendron simplex Lesquereux, p. 454, pl. $\mathrm{XLV}$, fig. 5 (acc. to Lesquereux 1880).

1868 Lepidodendron rimosum, Dawson, p. 487, fig. 169D.

* ?1868 Lepidodendron plicatum Dawson, p. 488, fig. 169C (acc. to Kidston 1911).

1869 Lepidodendron dicrocheilum Wood, p. 346, pl. IX, figs. 6, 6a (spelling corrected from Wood 1860).

1879-80 Lepidodendron rimosum, Lesquereux, pp. 392394, pl. LXIV, fig. 11.

p 1899 Lepidodendron rimosum var. retocorticatum White, pp. 196-198, pl. LIV, figs. 4-4a; non pl. LIV, figs. 3-3b (photograph unclear, but two drawings show well-defined leaf scars containing a leaf trace as well as parichnos markings; this specimen is different from that figured in pl. LIV, figs.

4, 4a, lacking cicatricules. White's pl. LIV, figs. 3, $3 \mathrm{a}-\mathrm{b}$ resembles "Lepidodendron" tijoui).

T 1935 Lepidodendron rimosum, Stockmans, p. 4, pl. II, fig. 4 (photograph of the holotype).

1944 Lepidodendron rimosum, Bell, p. 90, pl. XLVI, fig. 2 (see Figs. 5a, b).

1958 Lepidodendron rimosum, Langford, p. 66, fig. 104.

1958 Lepidodendron veltheimi, Langford, p. 66, fig. 103.

* 1960 Lepidodendron taxandricum Stockmans and Willière, p. 306, 308, pl. XIII, fig. 9; pl. XIV, fig. 6.

p ?1962 Lepidodendron bretonense Bell, pl. XLVII, fig. 6 (decorticated); pl. XLVIII, fig. 6 (specimen with elongate, fusiform cushions comparable with "Lepidodendron" rimosum); non p. 53-54, pl. XLVII, fig. 5 (= Diaphorodendron decurtatum); pl. XLVIII, fig. 4 (= Diaphorodendron decurtatum); non pl. XLIX, fig. 2 (small leafy branches from same locality as others figured as Lepidodendron pictoense).

1966 Lepidodendron rimosum, Bell, pl. VIII, fig. 3 (same as Bell, 1944, pl. XLVI, fig. 2).

? 1974 Lepidodendron rimosum, Tidwell et al., p. 124, 126, pl. 2, fig. 1 (poorly preserved); pl. 5, fig. 6 (difficult to judge).

T 1997 Lepidodendron rimosum, Kvaček and Straková, p. 130, pl. 44, fig. 4 (photograph of the holotype, which Kvaček and Straková regarded as a decorticated stem to be included in "Lepidodendron sp. indet. (Aspidiaria)".

p 2006 Lepidodendron rimosum, Wittry, p. 107, fig. 1 (copy of Lepidodendron simplex Lesquereux, 1866); fig. 2 (same as Lesquereux 1879-1880, pl. LXIV, fig. 11); non fig. 3 (= Lepidodendron aculeatum).

Excludenda:

1957 Lepidodendron rimosum, Janssen, p. 43, fig. 21 (difficult to judge, but almost certainly not "Lepidodendron" rimosum).

1982 Lepidodendron cf. rimosum, Oleksyshyn, pp. 1415, fig. 7C (decorticated specimen, indeterminable).

1985 Lepidodendron cf. rimosum, Gillespie and Crawford, p. 250, pl. I, fig. 6 (difficult to judge, but comparable to Bergeria dilatata).

REMARKS. A single specimen showing the imprint of the bark of what seems to have been a large tree was figured by Bell $(1944,1966)$ as Lepidodendron rimosum. We have not re-examined this specimen, but the rhomboidal, elongate leaf cushions, with rounded lateral angles and sharp bases and apices, slightly inflected in opposite directions, closely resemble those of Sternberg's type (photographed by Stockmans 1935 and Kvaček and Straková 1997; see also the copy of Sternberg's figure in Crookall 1964). The prominent, relatively small, rhomboidal leafscars, placed a little above the middle of a cushion are also similar. Although the holotype of "Lepidodendron" rimosum has much larger interareas than the Canadian specimen, this is not necessarily significant for a specific distinction. The amount of separation between leaf cushions (i.e., the width of interareas) depends largely on their position on the stem, with the older parts commonly showing larger interareas. Indeed, the wide separation between leaf cushions in the holotype made Němejc (1947, p. 62) consider that it merely represented a developmental stage in the lower part of an old tree and that this character was useless for specific distinction. This species is too poorly understood for a precise generic attribution. Therefore, we retain it provisionally in Lepidodendron.

COMPARISONS. Bell's $(1944,1966)$ specimen of "Lepidodendron" rimosum may be compared with the rare species "Lepidodendron" fusiforme (as figured by Crookall 1964). That species has elongate leaf cushions that are similar to those of "Lepidodendron" rimosum, but lack the very wide interareas in specimens of equivalent size 

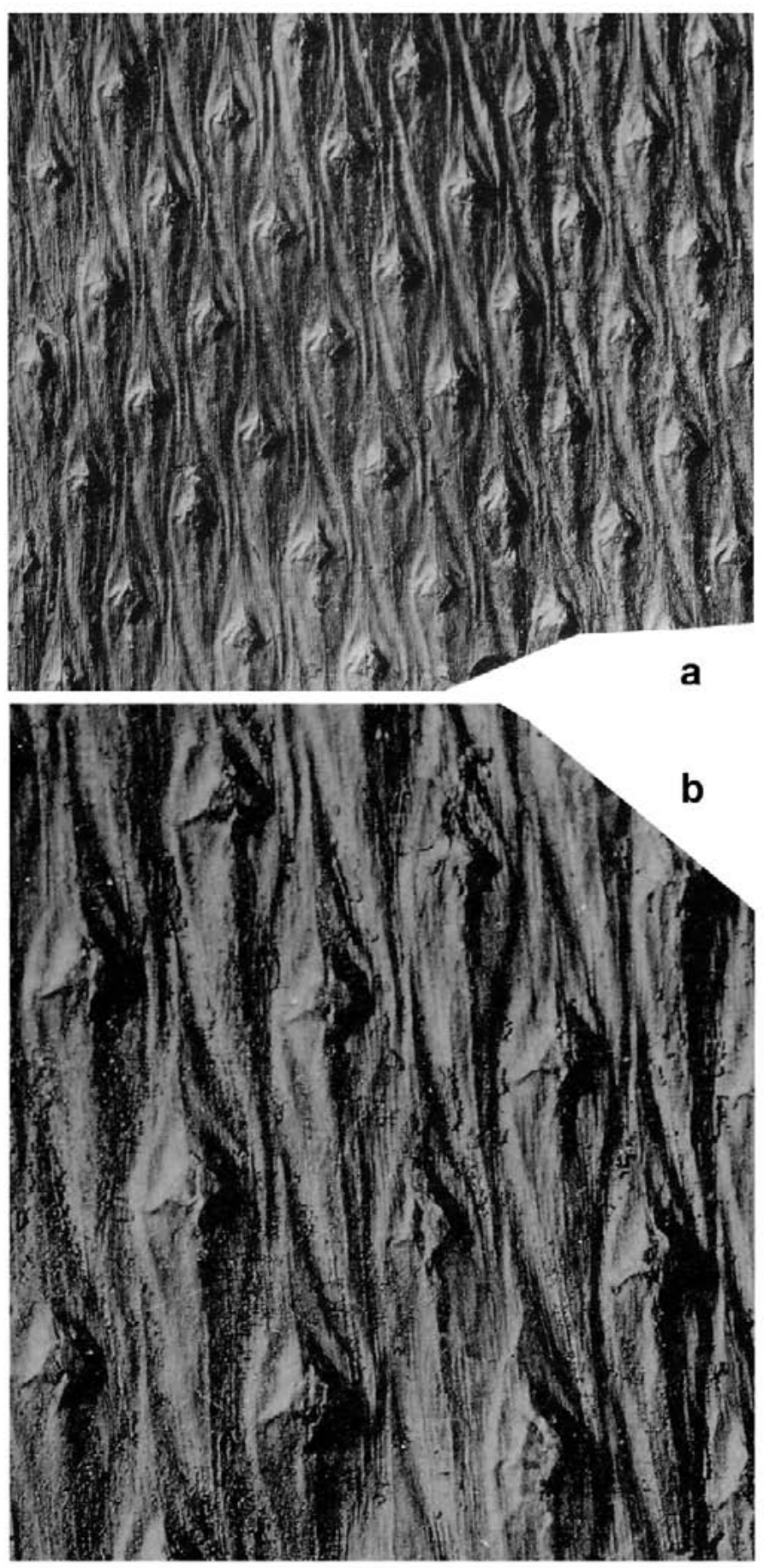

Figure 5. "Lepidodendron" rimosum. GSC 9551. (a) Partial copy (x 1) of the photograph published by Bell (1944, pl. XLVI, fig. 2; 1966, pl. VIII, fig. 3). Specimen slightly decorticated. Origin: Springhill, roof of unspecified coal seam. (b) Enlargement ( $\left.\begin{array}{ll}x & 2\end{array}\right)$ of part of 5a. Repository: Geological Survey of Canada, Ottawa. (representing the older part of the tree). Also, the lateral angles of the cushions are more acute or only very slightly rounded in "Lepidodendron" fusiforme. The discussions presented by Němejc (1947) and Crookall (1964) show that "Lepidodendron" fusiforme and "Lepidodendron" rimosum have often been confused or regarded as synonyms.

STRATIGRAPHIC AND GEOGRAPHIC DISTRIBUTION. According to Crookall (1964), the species, although uncommon, is recorded throughout the entire Westphalian of Great Britain. Sternberg's holotype originated from the Bolsovian of the Radnice Member, Kladno Formation, Bohemia. Lepidodendron taxandricum, which is regarded as a synonym, originated from the upper Westphalian A (upper Langsettian) of the Campine (Kempen) coalfield in Belgium.

OCCURRENCE IN THE MARITIME PROVINCES, CANADA. CUMBERLAND BASIN (NOVA SCOTIA): Dawson (1868). Bell (1944): Springhill (GSC 9551). Bell (1966): Springhill (GSC 9551 — same as Bell, 1944). PICTOU COALFIELD (Nova scotia): Bell (1962): locality 948 (GSC 810 - cf.); locality 990 (GSC 811 - cf.). sydney basin (nova scotia): Dawson (1868).

OCCURRENCE IN THE UNITED STATES. ILLINOIS: Lesquereux (1866), Lesquereux (1879-1880), Langford (1958), Wittry (2006). MISSOURI: White (1899). PENnSylvannia: Wood $(1860,1869)$. UTAH: Tidwell et al. (1974).

"Lepidodendron" cf. tijoui Lesquereux 1870 (Figs. 6a-b)

* 1870 Lepidodendron Tijoui Lesquereux, p. 431, pl. XXIV, figs. 1-3b.

?p 1899 Lepidodendron rimosum var. retocorticatum White, pl. LIV, figs. 3-3b; non pl. LIV, figs. 4-4a.

p 1940 Lepidodendron rimosum, Janssen, pp. 17-19, pl. III, fig. 2 (photograph of holotype of Lepidodendron tijoui, which Janssen regarded as synonymous with Lepidodendron rimosum, in agreement with Jongmans 1929); non pl. IV (holotype of Ulodendron elongatum, the ulodendroid condition of Lepidodendron rimosum according to Janssen).

? 1985 Lepidodendron rimosum, Wnuk, pp. 158-169, pl. 1, figs. 1-6; pl. 3, fig. 11 (branch system); text-fig. 2; text-fig. 12 (tree reconstructions).

DESCRIPTION. Leaf cushions spirally arranged and separated by relatively large, unornamented interareas. They are fusiform, elongate and longitudinally symmetrical, with pointed upper and lower angles that are only very slightly 
inflected in opposite directions; lateral angles rounded. Dimensions: $15-20 \mathrm{~mm}$ long and 3-3.5 $\mathrm{mm}$ broad, with maximum width in the upper third; length/breadth ratio $\approx$ 5. Leaf scar prominent, rhomboidal, broader than long, with rounded upper and lower angles and acute lateral angles, occupying nearly the entire cushion width, $1.5-2 \mathrm{~mm}$ long and $2.8-3 \mathrm{~mm}$ broad; the three punctiform prints are placed in line, near the middle of the scar.

REMARKS. A single specimen from the Joggins section (locality 1343), cited as Lepidodendron rimosum by Bell (1944), but not figured, is included here as "Lepidodendron" cf. tijoui (Figs. 6a, b). Unfortunately, this specimen is not very well preserved due to the coarse grain size of the containing sediment. The elongate shape of the fusiform leaf cushions with acuminate, slightly inflected apex and base, and the position of the small leaf scars in the upper one-third of the cushion, as well as the presence of wide interareas, allow a general comparison with "Lepidodendron" rimosum. However, Bell's specimen has smooth, apparently unornamented interareas, whereas the type material of "Lepidodendron" rimosum has more or less continuous, clearly marked lines parallel to the cushion margins. Bell's specimen also shows a leaf scar that is a little broader than long and which occupies virtually the entire cushion width. In "Lepidodendron" rimosum it is longer than broad and occupies a little over one-third of the width. This suggests that "Lepidodendron" tijoui may be the better identification. Due to the relatively large size of both cushions and leaf scars in the holotype of "Lepidodendron" tijoui and the presence of interareas in the present specimen, we make the species attribution only tentatively.

Although the apparent absence of infrafoliar parichnos and relatively flat leaf cushions suggest a possible attribution to Diaphorodendron, we consider that this specimen shows insufficient detail for a precise generic attribution.

STRATIGRAPHIC AND GEOGRAPHIC DISTRIBUTION. The holotype of "Lepidodendron" tijoui is from St. Johns, Illinois.

OCCURRENCE IN THE MARITIME PROVINCES, CANADA. CUMBERLAND BASIN (NOVA SCOTIA): Bell (1944): locality 1343 (one specimen without catalogue number).

OCCURRENCE IN THE UNITED STATES. ILLINOIS: Lesquereux (1870), Janssen (1940). MISsourI: White (1899). PENNSYLVANIA: Wnuk (1985).

Genus Lepidophloios Sternberg 1825

TYPE. Lepidophloios laricinus (Sternberg 1820) Sternberg 1825
DIAGNOSIS. Arborescent lycopod stems covered with spirally arranged, protruding and partially overlapping leaf cushions of rhomboidal shape, contiguous, and broader than long. Leaf scars situated at or near the base of the cushion, transversely oval or rhomboidal, with a vascular trace and two lateral adjacent markings situated usually below the middle. Ligule pit above the leaf scar.

REMARKS. Lepidophloios is an arborescent lycopod genus introduced for stem impressions by Sternberg (1820). This genus of tree is apparently similar to Lepidodendron in size and general construction, with a profusely branched crown constituted by several consecutive dichotomies. The main distinguishing feature is the strongly protruding, downwards directed leaf cushions, overlapping partially on compression, with each cushion showing more or less rounded lateral and basal angles. The protruding leaf scar area is wider than long. Thomas (1977) was the first to record cuticles of Lepidophloios; and DiMichele (1979) described anatomically preserved material showing two kinds of branching, lateral branches and branches produced by successive isotomous dichotomy. He also reconstructed the crown of the tree.

Lepidophloios laricinus (Sternberg 1820) Sternberg 1825 (Figs. 7, 8d-g)

* 1820 Lepidodendron laricinum Sternberg, pp. 21-23, Taf. XI, figs. 2-4.

$\$ 1825$ Lepidofloyos laricinum, Sternberg, p. xiii.

* 1837 Sigillaria Serlii Brongniart, pp. 433-434, pl. 158, figs. 9, 9A (upside down) (acc. to Goldenberg 1862).

* 1866 Lepidophloios obcordatus Lesquereux, p. 457, pl. XLI, figs. 1, 2 (acc. to Kidston 1886).

p 1884 Lepidophloios dilatatus Lesquereux, pl. CV, fig. 4; non pp. 781-783, pl. CV, fig. 2 (= Lepidophloios macrolepidotus Goldenberg); non pl. CV, fig. 1 - this specimen appears to represent a lycopsid strobilus with sporangia and megasporangia), fig. 3 (decorticated).

p 1897 Lepidophloios Acadianus Dawson, pls I, II; non pp. 63-64, pl. IV, fig. above; non pl. III (stem with attached leaves); non pl. IV below (strobili); non pl. V (stems with branch scars); non pl. VI (transverse sections); non pl. VII (poorly preserved stems with branch scars); non pl. VIII (poorly presrved stem with branch scars).

p 1899 Lepidophloios Van Ingeni White, pl. LVI, figs. 1-2b; non pp. 205-210, pl. LVI, figs. 3-8 (= Lepidophloios macrolepidotus); non pl. LVII, figs. 1, 1a (= Lepidophloios macrolepidotus); non pl. LXI, fig. 1c (= Lepidophloios macrolepidotus); non pl. LXII, fig. $\mathrm{f}$ (= Lepidophloios macrolepidotus); non pl. LXIII, fig. 5 (= Lepidophloios macrolepidotus); non pl. LVIII, fig. 1 (leafy branches). 

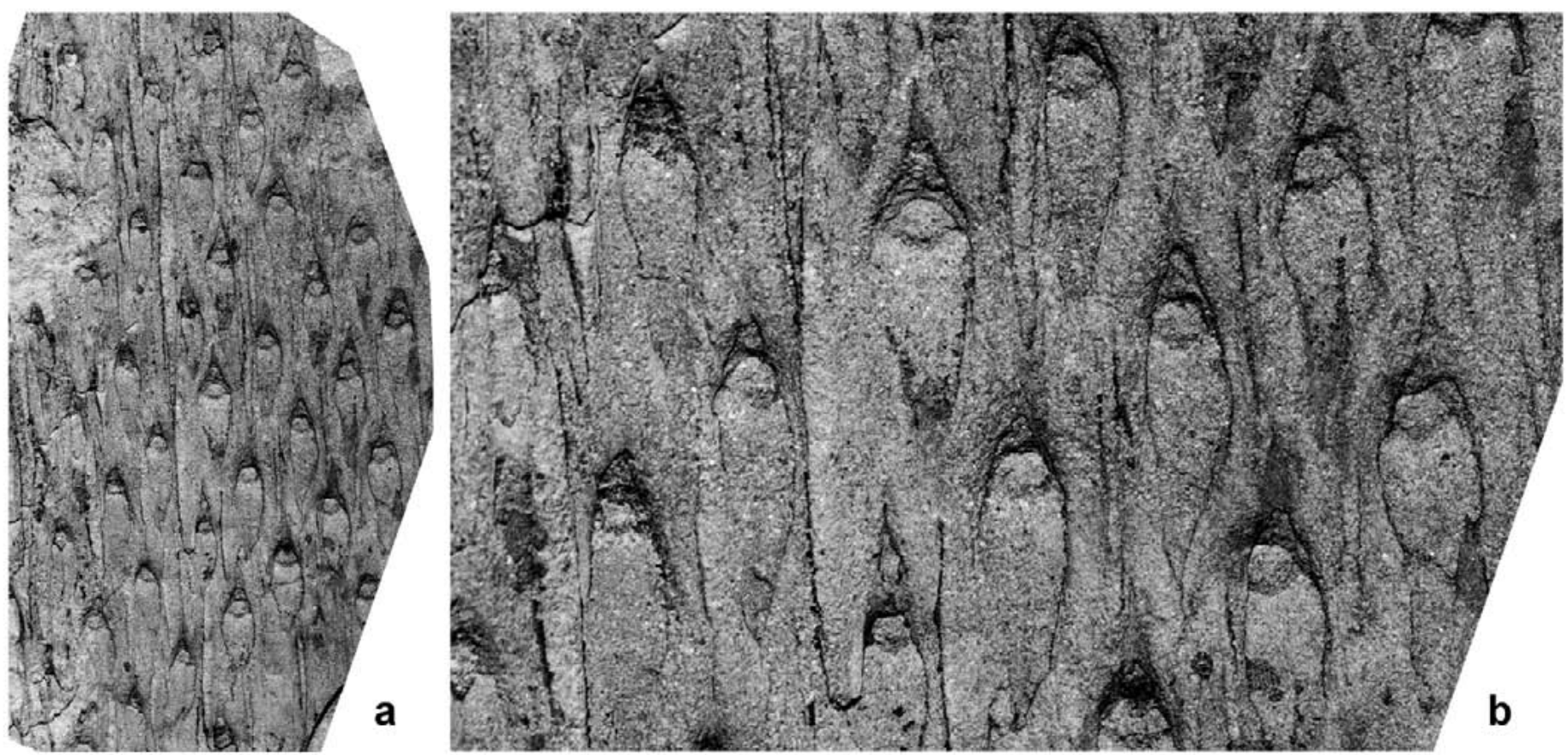

Figure 6. (a) "Lepidodendron" cf. tijoui (x 1). Origin: Joggins, Logan's division 4, beds of coal group no 29 (locality 1343). (b) "Lepidodendron" cf. tijoui. Enlargement (x 3) of part of 6a showing the little broader-than-long leaf scars that occupy practically the entire cushion width. Repository: Geological Survey of Canada, Ottawa.

1937 Lepidophloios laricinus, Jongmans, p. 400, pl. 16, fig. 29.

1938 Lepidophloios laricinus, Bell, p. 102, pl. CI, fig. 4.

1940 Lepidophloios laricinus, Bell, p. 126, pl. VIII, figs. 3, 4.

1940 Lepidophloios laricinus, Janssen, pp. 20-21, pl. III, fig. 3 (photograph of the holotype of Lepidophloios obcordatus).

v p 1944 Lepidophloios laricinus, Bell, pp. 93-94, pl. L, fig. 1; pl. LVI, fig. 1 (upside down); pl. LVIII, fig. 1, fig. 4 (refigured here as Fig. 8g); pl. LXI, fig. 1 (refigured here as Fig. 7); non pl. LVII, fig. 4 (= Lepidophloios macrolepidotus); non pl. LVIII, fig. 3 (= Lepidophloios macrolepidotus -

figured also by Bell 1966, pl. VIII, fig. 2); non pl. LX, fig. 5 (stem with ulodendroid branch scar).

1957 Lepidophloios laricinus, Janssen, pp. 47-48, fig. 26.

1957 Ulodendron or Lepidophloios, Janssen, p. 52, fig. 32 (upside down).

1958 Lepidophloios laricinus, Langford, p. 78, fig. 132 (poorly figured).

1959 Lepidophloios laricinus, Canright, p. 20, 28, pl. 1, fig. 13 (poorly preserved).

v p1966 Lepidophloios laricinus, Bell, pl. XXVIII, fig. 4 (terminal part of branch with attached leaves); non pl. VIII, fig. 2 (= Lepidophloios macrolepidotus); non pl. XII, fig. 1 (forma Halonia tortuosa decorticated stem with halonial scars).
1968 Lepidophloios van-ingeni, Basson, pp. 46-48, pl. 2, fig. 4.

1974 Lepidophloios laricinus, Tidwell et al., pp. 132-134, pl. 3, fig. 2.

1974 Lepidophloios cf. larcinus, Jennings, p. 462, pl. 1, fig. 3 (as Lepidophloios sp. in plate explanation).

1975 Lepidophloios cf. L. laricinus, Boneham, p. 96, pl. 1, fig. 2 (upside down).

? 1977 Lepidophylloides laricinus (sic), Gastaldo, p. 136 (assigned to Lepidophloios in text), fig. 9 (poorly figured).

k 1977 Lepidophloios laricinus, Thomas, pp. 275-278, pl. 33, fig. 3, figs. 4-6 (cuticles); pl. 34, figs. 1-3 (cuticles); text-figs. 2-3A-F.

1978 Lepidophloios laricinus, Gillespie et al., p. 47, 52, pl. 16, fig. 1, fig. 6 (with Halonia strobilar scars).

1980 Lepidophloios laricinus, Jennings, p. 150, pl. 1, fig. 1.

p 1980 Lepidophloios laricinus, Zodrow and McCandlish, p. 82, pl. 123, fig. 3; non pl. 123, fig. 2 (decorticated); non pl. 124, fig. 1 (= Diaphorodendron decurtatum).

1985 Lepidophloios laricinus, Gillespie and Rheams, p. 194, 200, 201, pl. III, fig. 7, fig. 8 (? - long leaves).

1985 Lepidophloios cf. laricinus, Lyons et al., p. 212, 220, 238, pl. IV, fig. D.

1985 Lepidophloios laricinus, Gillespie and Crawford, p. 250, 252, pl. I, fig. 5.

1989 Lepidophloios laricinus, Gillespie et al., p. 5, pl. 1, fig. 12. 


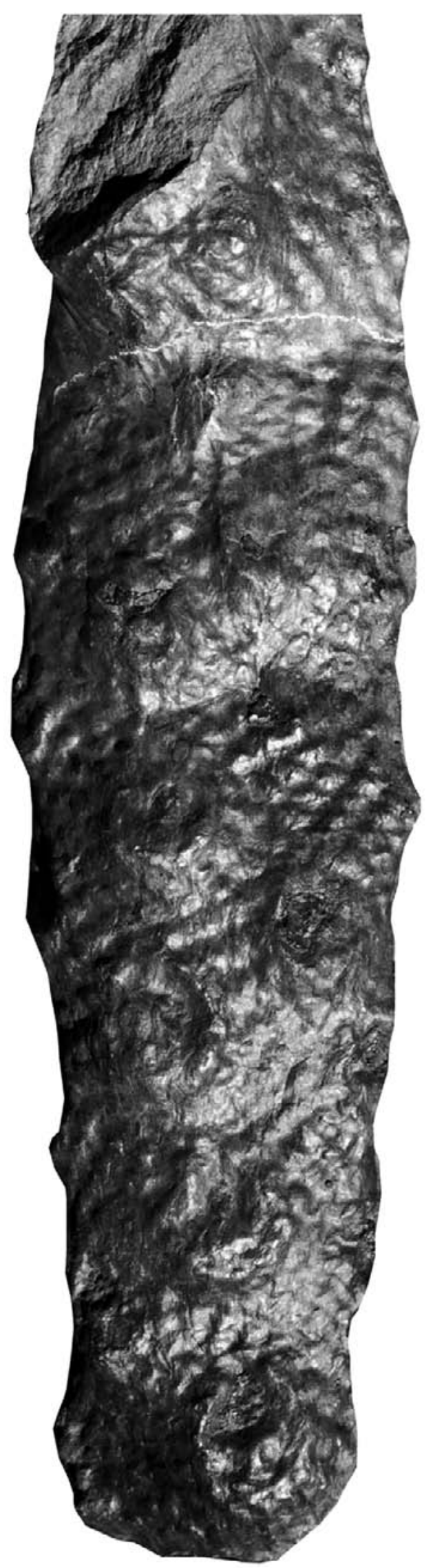

T 1992 Lepidodendron laricinum, Kvaček and Kvaček, Tab. I, fig. 2 (photograph of part of specimen illustrated by Sternberg 1820, Taf. XI, fig. 2).

p 1996 Lepidophloios laricinus, Cross et al., p. 403, fig. 23-4.4; non fig. 23-4.3 (to be compared with Lepidophloios acerosus Lindley and Hutton).

T 1997 Lepidofloyos laricinum, Kvaček and Straková, pp. 93-94, pl. 29 (photograph of specimen in Sternberg 1820, Taf. XI, fig. 3); pl. 31 (Sternberg 1820, Taf. XI, fig. 2).

2005 Lepidophloios laricinus, Dilcher et al., p. 157, figs. 1.5-1.7.

2005 Lepidophloios laricinus, Dilcher and Lott, pl. 118, fig. 1, fig. 2 (decorticated), fig. 3; pl. 119, fig. 1 (same as Dilcher et al. 2005, fig. 1.5), fig. 3, fig. 4 (poorly preserved).

? 2006 cf. Lepidophloios laricinus, Calder et al., p. 180, 182, fig. 10D (difficult to judge from illustration).

2006 Lepidophloios sp., Wittry, p. 109, figs. 1, 2; fig. 3 (same as Janssen 1957, fig. 32).

Excludenda:

1968 Lepidophloios larcinus (sic), Abbott, p. 9, pl. 12, fig. 6 (sketch of Sigillaria brardii); pl. 19, fig. 4 (= Sigillaria brardii).

DESCRIPTION. Leaf cushions overlapping, rhomboidal in outline, much broader than long, with acute lateral angles, obtuse upper angle, and a rounded lower angle. Keel absent. Dimensions: $4-5 \mathrm{~mm}$ long and $6-10 \mathrm{~mm}$ broad; ratio = 0.5-0.6. Leaf scars occurring near the cushion apex, strongly protruding and squashed downwards on compression, transversely rhomboidal, elongate, with lateral angles very sharp and the upper and lower angles rounded, occupying approximately one third of cushion area. Dimensions: 2-3.5 $\mathrm{mm}$ long and 3-7 $\mathrm{mm}$ broad. In its lower part, the leaf scar bears three small rounded markings in line; only the central, larger cicatricule (vascular trace) is clearly visible in the leaf scar.

REMARKS. Bell (1944) figured several specimens from the Cumberland Basin as Lepidophloios laricinus, but two different species seem to be represented. One is characterized by the small leaf cushions and scars of Lepidophloios laricinus, whereas the other displays larger leaf cushions similar to those of Lepidophloios acadianus (a synonym

Figure 7. Lepidophloios laricinus (x 1). GSC 4503. Slightly flattened stem cast showing subcircular halonial (strobilar) scars corresponding to irregularly placed protuberances. Poorly preserved leaf cushions suggest protrusions. Previously figured in Bell (1944, pl. LXI, fig. 1). Origin: Joggins section, unspecified coal seam (locality 1388). Repository: Geological Survey of Canada, Ottawa. 
of Lepidophloios macrolepidotus - see later). Bell (1944, 1966) also figured several specimens with ulodendroid and halonial (branch and strobilar) scars. Specimen GSC 4503 (Bell 1944, pl. LXI, fig. 1 - refigured here in Fig. 7) is a stem fragment with subcircular scars in a helicoidal pattern. It has transversely elongate leaf cushions, thus allowing its identification as Lepidophloios. This specimen is only slightly flattened, preserving most of its three dimensional aspect and thus allowing the helicoidal pattern of scars to be followed around the branch. These subcircular scars are set on protuberances. This is the Halonia condition that Jonker (1976), following Renier (1910), interpreted as slight elevations of cortical tissue supporting pedunculate strobili. This interpretation agrees with the reconstruction by Hirmer (1927, fig. 263). A central depression on the subcircular protuberance would mark the place of insertion of the strobilar stalk. Bell (1966, pl. XII, fig. 1) figured a similar specimen with halonial scars, but more poorly preserved. Both the latter specimen and the one figured here are from the same locality (1388) at Joggins.

A different, larger kind of scar of more elliptical shape and forming a depression on large branches or stems is exemplified by the negative print of a branch surface as figured by Bell (1944, pl. LVIII, fig. 4 - refigured here in Fig. 8 g). This kind of scar was interpreted by Renier (1910) and Jonker (1976) as corresponding to an adventitious branch. Adventitious branch scars seem uncommon, but they have been found on several different kinds of lycopsid stems, e.g., on Bothrodendron (Crookall 1964, pl. LXXIII, fig. 5) and Bergeria (Kidston 1893, pl. III, fig. 9, fig. 10, as Lepidodendron landsburgii - refigured as Lepidodendron ophiurus by Crookall 1964, pl. LXIII, fig. 1), as well as in Lepidophloios.

Some of the stem remains with ulodendroid scars are not clearly identifiable as Lepidophloios laricinus. For instance, specimen GSC 8556 (Bell 1944, pl. LX, fig. 5), which is unidentifiable either generically or specifically (see later), is a decorticated, poorly preserved stem fragment with rhomboidal leaf cushions, longer than wide, and an ulodendroid branch scar.

COMPARISONS. The leaf cushions of Lepidophloios macrolepidotus are much larger, up to four times the size of those of Lepidophloios laricinus. Also, the leaf cushions of Lepidophloios macrolepidotus are more equidimensional and do not protrude as much as those of Lepidophloios laricinus. The leaf scars of Lepidophloios macrolepidotus are more rhomboidal and occur at the extreme base of cushions. Moreover, the ligule pit in Lepidophloios macrolepidotus is more clearly separate from the leaf scar. According to Thomas (1977), the stomatal frequencies also differ, with 250 per $\mathrm{mm}^{2}$ in Lepidophloios laricinus and 130 per $\mathrm{mm}^{2}$ in cuticle preparations of material from the Joggins section. Thomas attributed the latter material to Lepidophloios acadianus (a synonym of Lepidophloios macrolepidotus).

Lepidophloios acerosus also possesses small, rhomboidal leaf cushions, but these are longer than broad, with a distinct keel (a feature absent in Lepidophloios laricinus); also its ligule pit occurs immediately above the leaf scar (in contrast to 1-1.5 $\mathrm{mm}$ above the leaf scar in Lepidophloios laricinus). According to Thomas (1977, p. 284), the cuticles of these two species are also different.

STRATIGRAPHIC AND GEOGRAPHIC DISTRIBUTION. Lepidophloios laricinus is quite common in Westphalian strata. It has been reported most often from the Langsettian and Duckmantian substages, and much more rarely from the (upper) Namurian (fide Crookall 1964). The type material is from the Radnice Member, Kladno Formation in Bohemia, of Bolsovian age. According to Wagner and Álvarez-Vázquez (2010), this species ranges from Langsettian to Cantabrian in the Iberian Peninsula, a longer range than is commonly accepted.

OCCURRENCE IN THE MARITIME PROVINCES, CANADA. CUMBERLAND BASIN (NOVA SCOTIA): Dawson (1897). Bell (1944): locality 636 (GSC 8601); locality 1045 (GSC 8567 + one piece without number with cf.); locality 1386 (one piece without catalogue number); locality 1388 $=2990$ (GSC 4503); locality 1982 (three pieces without catalogue number); locality 2989 (GSC $8561+$ three pieces without catalogue number). Bell (1966): locality $1388=$ 2990 (GSC 14930). Zodrow and McCandlish (1980). MINAS BASIN (NOVA SCOTIA): Bell (1944): locality 77 (GSC 8216). SYDNEY BASIN (NOVA SCOTIA): Bell (1938): locality 498 (GSC 3373). Bell (1966): locality 1331 (GSC 14935). MINTO COALFIELD (NOVA SCOTIA): Bell (1940): locality 2656 (GSC 10360); locality 2746 (GSC 10364).

OCCURRENCE IN THE UNITED STATES. ALABAMA: Gillespie and Rheams (1985), Lyons et al. (1985), Dilcher and Lott (2005), Dilcher et al. (2005). Colorado: Jennings (1980). GEORGIA: Gillespie and Crawford (1985), Gillespie et al. (1989). ILLINOIs: Lesquereux (1866), Janssen (1940, 1957), Langford (1958), Jennings (1974), Boneham (1975), Gastaldo (1977), Wittry (2006). Indiana: Canright (1959). MIssourI: White (1899), Basson (1968). OHIO: Cross et al. (1996). UTAH: Tidwell et al. (1974). WEST VIRGINIA: Jongmans (1937), Gillespie et al. (1978).

\section{Lepidophloios macrolepidotus Goldenberg 1862} (Figs. 8a-c)

1855 Lomatophloyos macrolepidotum Goldenberg, $\mathrm{p}$. 22 (nomen nudum).

* 1862 Lepidophloios macrolepidotum Goldenberg, pp. 37-40, Taf. 14, fig. 25 (upside down) (as Lomatophloyos macrolepidotum in plate 

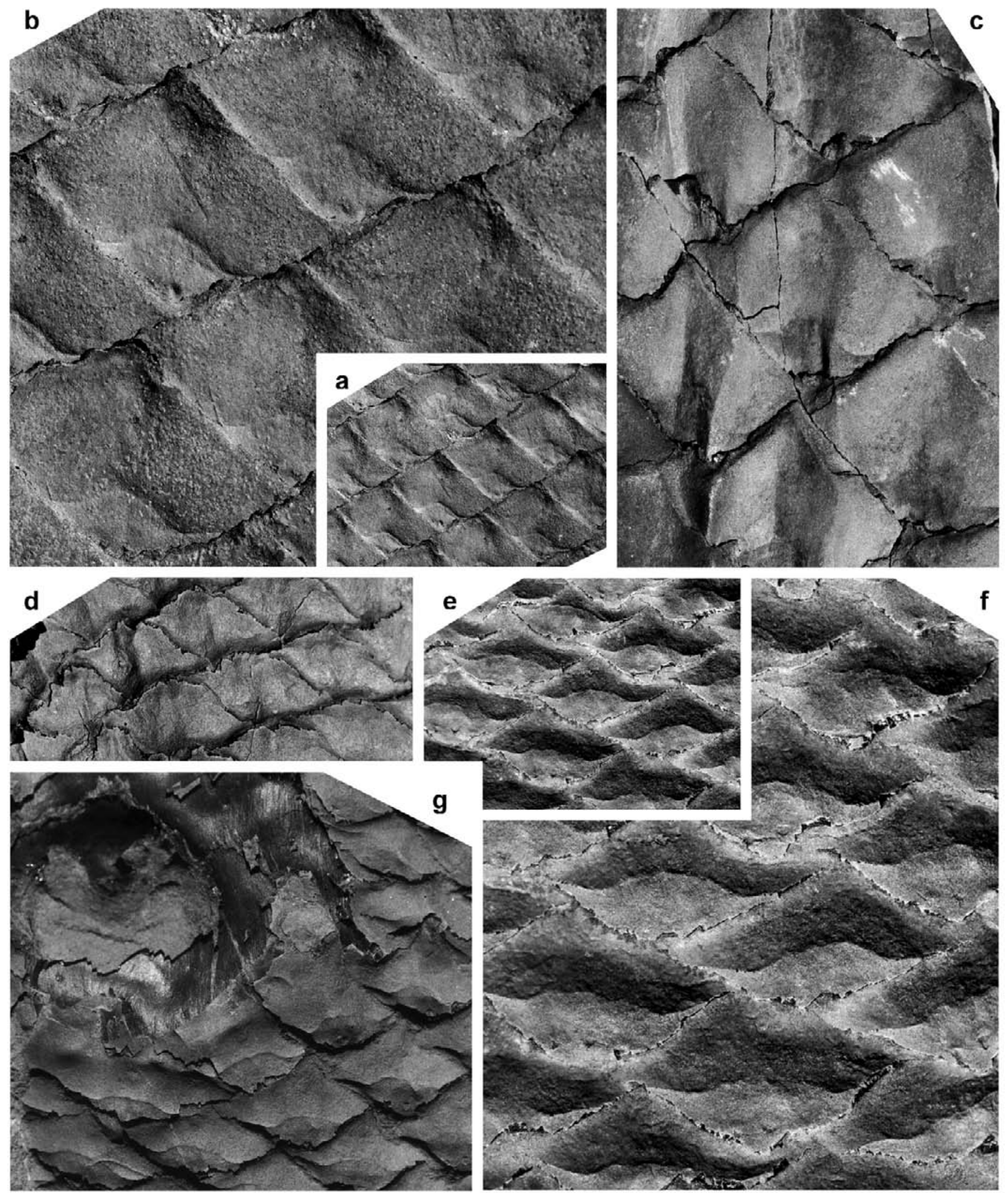
explanation).

* 1862 Lomatophloios intermedium Goldenberg, pp. 28-29, Taf. XV, figs. 3, 4.

p 1862 Lepidophloios laricinum, Goldenberg, Taf. XVI, fig. 1; non Taf. XVI, figs. 2-6A (= Lepidophloios laricinus), fig. 7 (strobili), fig. 8 (Cyperites-type leaves).

*p 1868 Lepidophloios Acadianus Dawson, p. 489, textfig. 171B, M (sketch of a leaf cushion); non textfig. 171A (reconstruction), figs. C-E (branch with halonial scars), fig. F (strobilus), fig. G (leaf), figs. $\mathrm{H}-\mathrm{L}$ (cross section).

* 1870 Lepidophloios? auriculatum Lesquereux, p. 439, pl. XXX, fig. 1 (upside down).

1879-80 Lepidophloios macrolepidotus, Lesquereux, $\mathrm{p}$. 424, pl. LXVIII, fig. 2 (upside down).

1879-80 Lepidophloios auriculatus, Lesquereux, pp. 421422, pl. LXVIII, fig. 3 (same as Lesquereux, 1870, pl. XXX, fig. 1), fig. 4.

*p 1884 Lepidophloios dilatatus Lesquereux, pp. 781-783, pl. CV, fig. 2; non pl. CV, fig. 1 (indeterminable strobilar fragment of lycopsid with sporangia and megaspores - possibly attributable to Omphalophloios?), fig. 3 (decorticated), fig. 4 (= Lepidophloios laricinus).

p 1897 Lepidophloios Acadianus Dawson, pp. 63-64, pl. IV, fig. above; non pls I, II (= Lepidophloios laricinus); non pl. III (stem with attached leaves); non pl. IV lower part (strobili); non pl. V (stems with branch scars); non pl. VI (cross sections); non pl. VII (poorly preserved stems with branch scars); non pl. VIII (poorly preserved stem with branch scars).

* p 1899 Lepidophloios Van Ingeni White, pp. 205-210, pl. LVI, figs. 3-8; pl. LVII, figs. 1, 1a; pl. LXI, fig. 1c; pl. LXII, fig. f; pl. LXIII, fig. 5; non pl. LVI, figs. 1-2b (= Lepidophloios laricinus); non pl. LVIII, fig. 1 (small branches with attached leaves).

v p 1944 Lepidophloios laricinus, Bell, pl. LVII, fig. 4; pl. LVIII, fig. 3; non pp. 93-94, pl. L, fig. 1 (Lepidophloios laricinus); pl. LVI, fig. 1 (Lepidophloios laricinus - upside down); pl. LVIII, fig. 4 (Lepidophloios laricinus); pl. LXI, fig. 1 (Lepidophloios laricinus); non pl. LVIII, fig. 1 (poorly figured but possibly Lepidophloios laricinus); non pl. LX, fig. 5 (ulodendroid branch scar).

1959 Lepidophloios macrolepidotus, Remy and Remy, p. 103, Abb. 81.

p 1964 Lepidophloios laricinus, Crookall, pl. LXXVIII, fig. 1 (upside down); pl. LXXIV, fig. 6 (? poorly preserved); non pp. 307-313, pl. LXXIV, fig. 2 (strobili), figs. 3-5 (poorly figured); non pl. LXXV, fig. 6 (Lepidophloios laricinus); non pl. LXXVIII, fig. 6 (upside down - Lepidophloios laricinus); non text-figs. 98 (copy of one of Sternberg's 1820 syntypes), 100c (drawing). v p1966 Lepidophloios laricinus, Bell, pl. VIII, fig. 2 (same as Bell 1944: pl. LVIII, fig. 3); non pl. XII, fig. 1 (poorly preserved stem with halonial scars); $\mathrm{pl}$. XXVIII, fig. 4 (branch with attached leaves).

1968 Lepidophloios vaningeni, Abbott, pp. 8-9, pl. 13, fig. 6 (sketch of leaf cushion).

k 1977 Lepidophloios macrolepidotus, Thomas, pp. 284286, pl. 35, figs. 3-6; text-figs. 35A-B.

kp 1977 Lepidophloios acadianus, Thomas, pp. 289-290, pl. 36, fig. 6 (impression), fig. 7 (cuticle of the same specimen); text-figs. 7B-D; non pl. 36, fig. 5 (stem with ulodendroid branch scars and small leaf cushions attributable, perhaps, to Lepidophloios laricinus - figured at half size); ? non text-fig. 7A (drawing = Lepidophloios laricinus?).

Excludenda:

1873 Lepidofloios Acadianus Dawson, p. 33, pl. IX, fig. 85 (cannot be judged from the illustration).

DESCRIPTION. Cushions imbricate, slightly overlapping, rhomboidal, slightly broader than long, flat, no keel; lateral angles acute, upper angle obtuse, and lower angle well rounded. Dimensions: $13-25 \mathrm{~mm}$ long and $23-32 \mathrm{~mm}$ broad; ratio $=0.5-1.0$. Leaf scars (situated on a protrusion of the cushion) transversely rhomboidal, with acute lateral angles and rounded upper and lower margins; showing three small, punctiform markings, not always clearly visible, fully aligned and close to the lower margin. Dimensions: up to 5 $\mathrm{mm}$ long and $8-10 \mathrm{~mm}$ broad. Ligule pit (often indistinct) at $4-5 \mathrm{~mm}$ above the leaf scar.

Figure 8. (previous page) (a) Lepidophloios macrolepidotus (x 1). Origin: Joggins section, coal group no 43 (locality 1982). (b) Lepidophloios macrolepidotus. Enlargement $(\mathrm{x} 3)$ of $8 \mathrm{~b}$ showing the rhomboidal leaf scars placed on a protrusion of the cushion and with the three punctiform markings very close to the lower margin. (c) Lepidophloios macrolepidotus (x 3). Origin: Joggins section, coal group $\mathrm{n}^{\circ} 43$ (locality 1982). (d) Lepidophloios laricinus (x 3). Origin: Joggins section, lower part of Logan's division 4 (locality 2989). (e) Lepidophloios laricinus (x 3) showing the overlapping, rhomboidal, broader than long leaf cushions. Origin: same as for 8d (locality 2989). (f) Lepidophloios laricinus (x 6). Same specimen as in $8 \mathrm{e}$. (g) Lepidophloios laricinus (x 3). GSC 8561. Specimen with a branch scar previously figured in Bell (1944, pl. LVIII, fig. 4). Origin: same as for 8d (locality 2989). Repository: Geological Survey of Canada, Ottawa. 
REMARKS. Bell (1944, p. 93) followed Kidston $(1886,1901)$ by including Lepidophloios acadianus in the synonymy of Lepidophloios laricinus, and suggesting that both Lepidophloios prominulus and Lepidophloios parvus might also belong to this species. However, Dawson (1897) defended the individual identity of his species on the basis of larger leaf cushion size, a different length/breadth ratio, and by the absence of a keel. Thomas (1977), who figured two specimens from Joggins, Nova Scotia, maintained Lepidophloios acadianus as a separate species on the basis of both cushion morphology and cuticle characteristics (larger epidermal cells and more stomata in Lepidophloios laricinus). He distinguished Lepidophloios acadianus from Lepidophloios macrolepidotus on its flatter leaf cushion and a more distinct ligule pit, which also appears more clearly separate from the leaf scar. Thomas (1977) described the epidermal cells as being of similar size in Lepidophloios acadianus, Lepidophloios macrolepidotus and Lepidophloios laricinus, but these cells have thicker anticlinal walls in Lepidophloios laricinus. He recorded different stomatal densities: 250 stomata per $\mathrm{mm}^{2}$ in Lepidophloios laricinus, 50 per $\mathrm{mm}^{2}$ in a specimen determined as Lepidophloios macrolepidotus, and about 130 per $\mathrm{mm}^{2}$ in the cuticles from Joggins material identified as Lepidophloios acadianus by Dawson (seven specimens in the Kidston collection, Geological Survey, London - numbers 2318 to 2324). However, stomatal density is known to vary with the degree of humidity, and is thus of lesser importance for species identity. We regard Lepidophloios acadianus as synonymous with Lepidophloios macrolepidotus on morphological criteria.

Goldenberg (1862) believed Lepidophloios macrolepidotus and Ulodendron majus to be closely related. We agree that Ulodendron majus could be a Lepidophloios. Unfortunately, its holotype seems to be lost (fide Crookall 1966, p. 488), and the original illustration (Lindley and Hutton 1831, pl. 5) is inadequate for a definitive opinion. We regard several species of Lepidophloios introduced by Lesquereux $(1870,1884)$ as synonyms of Lepidophloios macrolepidotus.

STRATIGRAPHIC AND GEOGRAPHIC DISTRIBUTION. Goldenberg (1862) and Remy and Remy (1959) recorded Lepidophloios macrolepidotus from the Bolsovian of Saarland, Germany, and Thomas (1977) recorded it from the Westphalian A (Langsettian) of Yorkshire. The specimen of Lesquereux's Lepidophloios dilatatus included in the synonymy above was from Cannelton, Pennsylvania, and is of Asturian age. The material described as Lepidophloios vaningenii by White (1899) is from Henry County, Missouri, and is of Bolsovian or early Asturian age.

OCCURRENCE IN THE MARITIME PROVINCES, CANADA. CUMBERLAND BASIN (NOVA SCOTIA): Dawson
(1868, 1897). Bell (1944): locality 1344 (one piece without catalogue number); locality $1388=2990$ (GSC 4503); locality 1687 (GSC 4499); locality 1982 (GSC 8563 + three pieces without catalogue number); locality 1983 (one piece without catalogue number). Bell (1966): locality 1982 (GSC 8563 - same as Bell 1944). Thomas (1977): Joggins (seven specimens deposited in London).

OCCURRENCE IN THE UNITED STATES. ILLINOIS: Lesquereux (1870), Lesquereux (1879-1884). MIssourI: Lesquereux (1879-1880), White (1899). oHIO: Abbott (1968). PENNSYLVANIA: Lesquereux (1879-1880).

\section{Ulodendroid branch scars}

1944 Ulodendron, Bell, p. 94, pl. LX, fig. 2. v p 1944 Lepidophloios laricinus, Bell, pl. LX, fig. 5; non pp. 93-94, pl. L, fig. 1 (Lepidophloios laricinus); non pl. LVI, fig. 1 (Lepidophloios laricinus - upside down); non pl. LVIII, figs. 1, 4 (Lepidophloios laricinus); non pl. LXI, fig. 1 (Lepidophloios laricinus); non pl. LVII, fig. 4 (= Lepidophloios macrolepidotus); non pl. LVIII, fig. 3 (= Lepidophloios macrolepidotus).

v p 1966 Lepidophloios laricinus, Bell, pl. XII, fig. 1 (as forma Halonia tortuosa); non pl. VIII, fig. 2 (= Lepidophloios macrolepidotus - same as Bell, 1944, pl. LVIII, fig. 3); non pl. XXVIII, fig. 4 (Lepidophloios laricinus).

REMARKS. Bell (1944, p. 94, pl. LX, fig. 2) recorded as Ulodendron a specimen (GSC 4492) representing an isolated ulodendroid branch scar. This specimen cannot be attributed to any particular lycopsid genus. This is also the case for another specimen (GSC 8556 - Bell 1944, pl. LX, fig. 5), which is a poorly preserved, decorticated stem remain showing rhomboidal leaf cushions and a large ulodendroid branch scar. It was included by Bell in Lepidophloios laricinus, as was the stem fragment recorded by Bell (1966, pl. XII, fig. 1) as "Lepidophloios laricinus forma Halonia tortuosa" (GSC 14930). All these decorticated stem remains are here regarded as indeterminable.

OCCURRENCE IN THE MARITIME PROVINCES, CANADA. CUMBERLAND BASIN (NOVA SCOTIA): Bell (1944): locality $1388=2990$ (GSC 4492); locality 1982 (GSC 8556). Bell (1966): locality $1388=2990$ (GSC 14930).

Genus Lepidostrobus Brongniart 1828a emend. Brack-Hanes and Thomas 1983

TYPE. Lepidostrobus ornatus Brongniart 1828a 
DIAGNOSIS (after Brack-Hanes and Thomas 1983). "Sporophylls in spirals on the cone axis. Axis with exarch vascular bundle surrounded by cortical zones. Sporangium with narrow attachment along its length to adaxial surface of sporophyll pedicel. Ligule on adaxial surface of pedicel distal to sporangium. Lateral laminae extending beneath sporangium. Abaxial keel along length of pedicel. Pedicel extended distally to upturned lamina and downturned heel. Cones microsporangiate. Microspores of Lycospora-type with broad equatorial flange and proximal ornamentation, distal surface ornament variable".

REMARKS. The genus Lepidostrobus was instituted by Brongniart (1828a) for strobili of Lepidodendron. Since then, it has been regarded as heterogeneous, including also the detached strobili of Lepidophloios and Bothrodendron. It has been applied to both permineralisations and adpressions. Heterosporous and homosporous strobili have been included, as well as strobili devoid of sporangial contents. Initially, sporophyll morphology was regarded as important for taxonomic purposes, but palynological studies have shown that strobili of similar morphological characters may have different spore types and may thus belong to different species. Brack-Hanes and Thomas (1983) emended the diagnosis of the genus based on a re-examination of the holotype of Lepidostrobus ornatus, specifying its microsporangiate or homosporous character, with miospores of Lycospora type. These authors also proposed that bisporangiate strobili should be recognized as Flemingites. These contain Lycospora microspores and megaspores of either Lagenicula or Lagenoisporites type.

The recognition of species of Lepidostrobus on morphological characters is fraught with difficulties. Complete specimens are rare and it is unusual to find remains showing both the axial part (allowing sporophylls and sporangia to be seen in relative proportion) and the external aspect, where it shows the shape of distal laminae. Therefore, most records can only be referred to Lepidostrobus sp. Only in a few cases is it possible to observe the proportionate size of sporophylls with regard to sporangia.

Detached sporophylls with or without an attached sporangium are included in Lepidostrobophyllum (see later).

\section{Lepidostrobus ornatus Brongniart 1828a}

(Fig. 9c)

* 1804 Strobilus, Parkinson, p. 438, pl. IX, fig. 1. 1828a Lepidostrobus ornatus Brongniart, p. 87, 174 (including Parkinson's specimen).

* 1831 Lepidostrobus variabilis Lindley and Hutton, p. 31, pl. 10, figs. 1-3; pl. 11 (acc. to Kidston 1886, who considered variabilis the correct specific epithet, rather than ornatus).

1831 Lepidostobus ornatus, Lindley and Hutton, p. 81, pl. 26, figs. 1, 2 .
* 1837 Lepidostrobus comosus Lindley and Hutton, p. 39, pl. 162 (synonym of Lepidostrobus variabilis acc. to Jongmans 1930).

? 1879-80 Lepidostrobus variabilis, Lesquereux, pp. 434435, pl. LXIX, fig. 26.

* 1893 Lepidostrobus squarrosus Kidston, p. 342, pl. IV, figs. 13-14 (acc. to Arber 1922).

* 1904 Lepidostrobus Kidstoni Zalessky, p. 104, pl. VII, figs. 3, 4 (to Lepidostrobus variabilis acc. to Jongmans 1930).

1940 Lepidostrobus variabilis?, Bell, p. 126, pl. IX, figs. 3-6; pl. X, fig. 1 (poorly figured).

v 1944 Lepidostrobus variabilis?, Bell, p. 95, pl. XLIX, fig. 6.

1959 Lepidostrobus sp., Canright, p. 21, pl. 1, fig. 7.

1959 Lepidostrobus cf. geinitzi, Canright, pl. 1, fig. 8 (photograph of strobilus that cannot be identified with Lepidostrobus geinitzii Schimper - see comments by Jongmans 1930, p. 485).

1963 Lepidostrobus variabilis, Wood, pp. 37-38, pl. 2, figs. 4-6.

1966 Lepidostrobus variabilis?, Bell, Pl. XX, fig. 2 (same as Bell 1940, pl. IX, fig. 4).

T 1966 Lepidostrobus ornatus, Crookall, pp. 493-496, pl. CI, figs. 2, 3; fig. 4 (photograph of Parkinson's 1804 specimen), fig. 5 .

1966 Lepidostrobus squarrosus, Crookall, p. 496, pl. CI, fig. 1 (holotype); text-fig. 145B.

1967 Lepidostrobus variabilis, Tidwell, pp. 20-21, pl. 2, fig. 8.

1975 Lepidostrobus ornatus, Tidwell, pl. 24, fig. 2 (figured as Lepidostrobus sp. in Tidwell 1998, pl. 26, fig. 2).

1977 Lepidostrobus ornatus, Gastaldo, p. 136, fig. 17.

p 1978 Lepidostrobus sp., Gillespie et al., p. 45, 52, pl. 15, figs. 4, 6; non pl. 15, fig. 1 (= Sigillariostrobus sp.).

T 1983 Lepidostrobus ornatus, Brack-Hanes and Thomas, p. 127, figs. 1 (copy of Parkinson's 1804 specimen), fig. 2 (photograph of holotype), fig. 3 (enlargement), figs. 4-6 (microspores).

1992 Lepidostrobus sp. cf. L. ornatus, Tidwell et al., p. 1015, figs. 3.1, 3.2.

1996 Lepidostrobus variabilis, Calder et al., p. 293, fig. 8e.

T 2001 Lepidostrobus ornatus, Cleal and Thomas, p. 19, fig. 7 (left - photograph of Parkinson's 1804 specimen; right - copy of Parkinson's original figure).

2006 Lepidostrobus variabilis, Wittry, p. 113, fig. 3.

REMARKS. As noted in the list of synonymy, Lepidostrobus variabilis is regarded generally as identical to Lepidostrobus ornatus (e.g., Němejc 1954). Bell (1944, p. 95) recorded several lycopsid strobili, not always well preserved, under the name of Lepidostrobus variabilis? and mentioned that more than one species might be represented. 

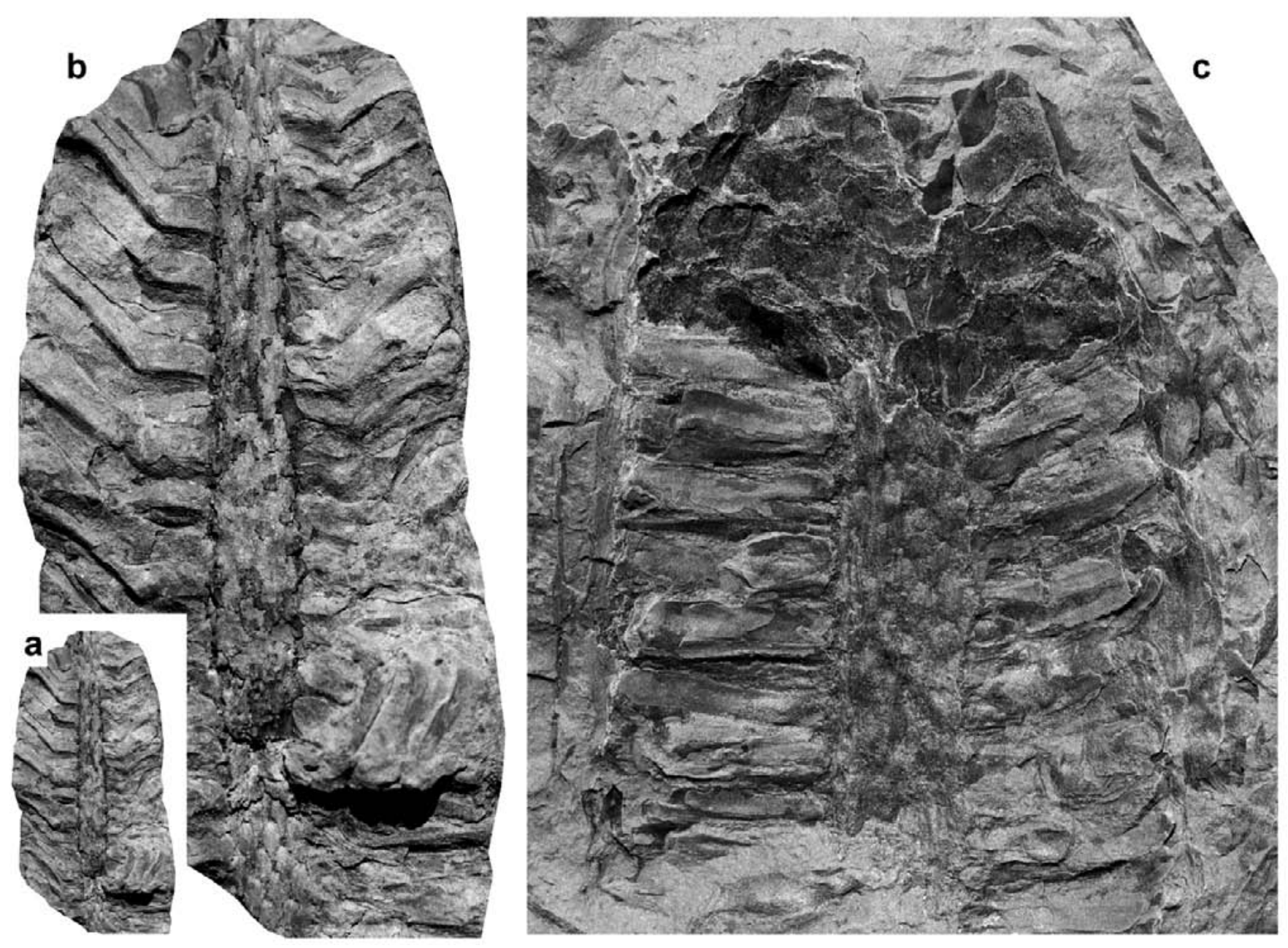

Figure 9. (a) Lepidostrobus sp. (x 1). Strobilus showing the axis and the orientation of the sporophylls. Origin: Inverness County, Chimney Corner (locality 1413C). (b) Lepidostrobus sp. Enlargement (x 3) of 9a so as to show reflexed sporophylls. Repository: Geological Survey of Canada, Ottawa. (c) Lepidostrobus ornatus (x 3). Apical part of a longitudinally broken specimen showing the wide axis and the sporangia. Origin: Joggins section ( $n^{\circ} 154$ of Donald Reid collection). Repository: Joggins Fossil Centre, Joggins, Nova Scotia.

Bell (1944, pl. XLIX, fig. 6) figured a single fragmentary specimen from the Joggins section representing the upper part of a cylindrical, elongate strobilus with a broad (about $9 \mathrm{~mm}$ ) central axis and long (12-14 $\mathrm{mm}$ ) sporophylls with apparently rather short distal laminae. The specimen figured here as Fig. 9 c, from the Donald Reid collection (also from Joggins), shows similar characters. Both specimens generally fit the description of Lepidostrobus ornatus (as in Brack-Hanes and Thomas 1983). The specimen illustrated as Figs. 9a-b, from Inverness County, Nova Scotia, has a broad central axis and reflexed sporophylls and can be attributed only generically.

From these observations, it is apparent that the name Lepidostrobus ornatus covers strobili identified on similar morphological characters independent of spore contents.
STRATIGRAPHIC AND GEOGRAPHIC DISTRIBUTION. Lepidostrobus ornatus is widely recorded with a range from Chokierian to Asturian. The specimen illustrated as "Strobilus" by Parkinson (1804) and included in the species by Brongniart (1828a) is from the Coal Measures of Derbyshire, England, of Westphalian age.

\section{OCCURRENCE IN THE MARITIME PROVINCES,} CANADA. CUMBERLAND BASIN (NOVA SCOTIA): Bell (1944): locality 1374 (GSC 8573); locality $1388=2990$ (one piece without catalogue number); locality 1413C (two pieces). Donald Reid collection (1999): DRC-99 151 + DRC-99 152 + DRC-99 154. SYDNEY BASIN (NOva SCOTIA): Calder et al. (1996). MINTO COALFIELD (NEW BRUNSWICK): Bell (1940): locality 1145 (GSC 10556); locality 1153 (GSC 10663); locality 2656 (GSC 10361); locality 2789 (GSC 10526); locality 2791 (GSC 10373). Bell (1966): locality 1153 (GSC 10663). 
OCCURRENCE IN THE UNITED STATES. ARIZONA: Tidwell et al. (1992). ILLINOIs: Gastaldo (1977). INDIANA: Canright (1959); Wood (1963). PENnsylvania: Lesquereux (1879-1880). UTAH: Tidwell (1967), Tidwell (1975). WEST VIRGINIA: Gillespie et al. (1978).

\section{Lepidostrobus cf. brongniartii Göppert in Berger 1848}

v p 1944 Lepidostrobus olryi, Bell, pl. LVII, fig. 3; non p. 95, pl. LVI, fig. 3 (poorly preserved specimen, better referred to as Lepidostrobus sp.); non pl. LX, fig. 1 (= Sigillariostrobus sp. indet.).

REMARKS. According to Chaloner (1953) Lepidostrobus olryi (now Flemingites olryi) is characterized by slender strobili. Chaloner obtained megaspores and microspores from several incomplete specimens of this species, which is also distinguished by short, closely adpressed sporophylls that are subtriangular with an acute apex.

All of Bell's (1944) records of this species are unconvincing. The fragmentary and poorly preserved specimen figured in his pl. LVI, fig. 3 (GSC 9608) cannot be determined specifically. The specimen illustrated in his pl. LX, fig. 1 (GSC 9948) shows a Sigillariostrobus axis with incompletely preserved sporophylls that are longer than is apparent from the photograph. A better-preserved specimen (Bell 1944, pl. LVII, fig. 3 - GSC 8564), shows longer, less closely adpressed sporophylls than occur in Lepidostrobus olryi, and might belong to Lepidostrobus brongniartii.

The narrow strobili of Flemingites olryi are similar to those of Lepidostrobus brongniartii as figured by Němejc (1954), whose identification is subject to reservation. In the absence of spore data, the specimen illustrated by Bell (1944, pl. LVII, fig. 3) can only be assigned tentatively to Lepidostrobus brongniartii.

Chaloner's (1953) brief synonymy list for Lepidostrobus olryi lacks Bell's (1944) records, as does the list compiled by Crookall (1966).

STRATIGRAPHIC AND GEOGRAPHIC DISTRIBUTION. Lepidostrobus brongniartii has been recorded from several localities in the Westphalian and Stephanian of Europe.

OCCURRENCE IN THE MARITIME PROVINCES, CANADA. CUMBERLAND BASIN (NOVA SCOTIA): Bell (1944): locality $1338=1686($ GSC 8564).

Genus Lepidostrobophyllum Hirmer 1927

TYPE. Lepidostrobophyllum fimbriatum (Kidston 1883) Allen 1961
REMARKS. This genus encompasses isolated sporophylls attributable to the families Lepidodendraceae and Diaphorodendraceae.

Lepidostrobophyllum lanceolatum (Lindley and Hutton 1831) Bell 1938

* 1831 Lepidophyllum lanceolatum Lindley and Hutton, p. 28, pl. 7, figs. 3, 4 .

* 1831 Lepidophyllum intermedium Lindley and Hutton, p. 123, pl. 43, fig. 3 (acc. to Jongmans 1930).

1858 Lepidophyllum lanceolatum, Lesquereux, p. 875, pl. XVII, fig. 1.

1879-80 Lepidostrobus lanceolatus, Lesquereux, pp. 436437, pl. LXIX, fig. 38.

* 1884 Lepidophyllum fallax Lesquereux, p. 786, pl. CVII, figs. 4, 5 (acc. to Jongmans 1930, p. 45 perhaps not conspecific with Lepidostrobophyllum lanceolatum).

$\$ 1938$ Lepidostrobophyllum lanceolatum, Bell, pp. 97-98, pl. XCVIII, figs. 10, 11.

* 1938 Lepidostrobophyllum lanceolatum var. constrictum Bell, pl. XCVIII, figs. 7-9.

1940 Lepidostrobophyllum lanceolatum, Bell, p. 127, pl. VII, fig. 3; pl. VIII, figs. 5, 6 .

v 1944 Lepidostrobophyllum lanceolatum, Bell, p. 96, pl. XLVIII, figs. 1, 2.

* 1952-53 Lepidophyllum acuminatifolium Stockmans and Willière, pp. 145-146, pl. XX, fig. 16.

1958 Lepidostrobophyllum lanceolatum, Langford, $\mathrm{p}$. 100, fig. 185.

? 1959 Lepidophyllum lanceolatum (?), Canright, pl. 1, fig. 10.

1964 Lepidophyllum lanceolatum, Read and Mamay, p. 9, pl. 8, fig. 2 (figured together with Mariopteris occidentalis and Sphenophyllum emarginatum).

1966 Lepidostrobophyllum lanceolatum var. constrictum Bell, pl. XXVII, fig. 2 (distal lamina only); pl. XXX, fig. 3.

T 1966 Lepidostrobus lanceolatus, Crookall, pp. 503-505, pl. XCIX, figs. 4, 5 (photographs of type material).

1969 Lepidostrobophyllum lancifolium, Darrah, p. 215 pl. 29, figs. 1, 2; fig. 3 (?) (Darrah refers to his p. 183, where this species is not mentioned).

1969 Lepidostrobophyllum (Lepidocarpon) majus forma lanceolatum, Darrah, pl. 29, fig. 7.

1970 Lepidostrobophyllum, Jennings, p. 170, fig. 8.

1974 Lepidostrobophyllum lanceolatum, Tidwell et al., pp. 136-138, pl. 5, fig. 1.

1977 Lepidostrobophyllum lanceolatum, Gastaldo, p. 135, fig. 16.

1977 Lepidostrobophyllum fallax, Gastaldo, p. 135, fig. 12.

1978 Lepidostrobophyllum, Gillespie et al., p. 52, pl. 14, fig. 4. 
1979 Lepidophylloides (Lepidophyllum) lanceolatum, Lyons and Darrah, p. 84, fig. 3j.

1980 Lepidostrobophyllum lanceolatum, Zodrow and McCandlish, p. 84, pl. 124, figs. 3, 4 (as var. constrictum Bell); pl. 126, fig. 3.

1980 Lepidostrobus lanceolatus, Zodrow and McCandlish, pl. 126, fig. 2.

1982 Lepidostrobophyllum lanceolatum, Oleksyshyn, p. 15, 18, figs. 7D, E.

1985 Lepidostrobophyllum majus?, Lyons et al., p. 212, 238, pl. IV, fig. A.

1996 Lepidostrobophyllum lanceolatum, Calder et al., p. 292, fig. 9c (figured together with Lobatopteris vestita sensu Wagner - see Wagner and ÁlvarezVázquez 2010, p. 317).

Excludenda:

1957 Lepidophyllum lanceolatum, Janssen, p. 63, fig. 46 (= Lepidostrobophyllum majus).

2006 Lepidostrobophyllum lanceolatus, Wittry, p. 115, fig. 1 (= Lepidostrobophyllum oblongifolium), fig. 2 (= Lepidostrobophyllum majus - same as Janssen 1957, fig. 46), fig. 3 (same as Lepidostrobus oblongifolius Lesquereux 1870: pl. XXX, fig. 3).

REMARKS. Bell (1944, pl. XLVIII, figs. 1-2) figures medium-sized leaves (about 50-55 $\mathrm{mm}$ long and $5 \mathrm{~mm}$ wide) each with a lanceolate lamina, being broadest at mid-length, a pointed apex, and a clearly marked central vein. These characters accord well with the description of this relatively common, easily recognizable species. We regard the three specimens from the Sydney coalfield recorded by Bell (1938, pl. XCVIII, figs. 7-9) as Lepidostrobophyllum lanceolatum var. constrictum as falling within the morphological range to be considered typical for this species. The varietal epithet refers to a constriction in the basal quarter of the lamina; we consider this feature insufficient to warrant varietal distinction.

COMPARISONS. Lepidostrobophyllum majus has a lamina that is larger, with its broadest part in the lower two thirds.

Lepidostrobophyllum lancifolium has a lamina with a sharply pointed apex and subparallel margins in its lower part; also, the lamina of this species widens at its base so as to constitute two small auricles.

STRATIGRAPHIC AND GEOGRAPHIC DISTRIBUTION. Lepidostrobophyllum lanceolatum is a relatively common species, recorded from Chokierian to Asturian strata. The type material comes from the Bensham seam at Jarrow Colliery, Durham, and is of Duckmantian age.

OCCURRENCE IN THE MARITIME PROVINCES, CANADA. CUMBERLAND BASIN (NOVA SCOTIA): Bell (1944): locality 1685 (GSC 8206). SYDNEY BASIN (NOVA SCOTIA): Bell (1938): locality no 2 colliery (GSC 3836 + GSC 4067); locality 513 (GSC 3304); locality 573 (GSC 3428); locality 715 (GSC 3420). Bell (1966): locality 1312 (GSC 14923); locality 1331 (GSC 14924). Calder et al. (1996). MINTO COALFIELD (NEW BRUNSWICK): Bell (1940): locality 1108 (GSC 10788); locality 1140 (GSC 10772); locality 2819 (GSC 10659).

OCCURRENCE IN THE UNITED STATES. ALABAMA: Lyons et al. (1985). ILLINOIs: Lesquereux (1870), Lesquereux (1879-1880), Langford (1958), Darrah (1969), Jennings (1970), Gastaldo (1977). indiana: Canright (1959). OKLAHOMA: Read and Mamay (1964). PENNSYLVANIA: Lesquereux (1879-1884), Oleksyshyn (1982). RHODE ISLAND: Lesquereux (1879-1884), Lyons and Darrah (1979). UTAH: Tidwell et al. (1974). WEST VIRGINIA: Gillespie et al. (1978).

Lepidostrobophyllum majus (Brongniart 1828a) Hirmer 1927

* 1822 Filicites (Glossopteris) dubius Brongniart, p. 232, pl. II, fig. 4.

1828a Lepidophyllum majus Brongniart, p. 87, 174 (including in synonymy Filicites (Glossopteris) dubius, as figured by Brongniart 1822).

* 1836 Lepidophyllum glossopteroides Göppert, p. 431, Taf. XLIV, fig. 3 (acc. to Kidston 1886).

* 1866 Lepidophyllum auriculatum Lesquereux, p. 457, pl. XXXVI, fig. 6 (acc. to Janssen 1940).

* 1870 Lepidophyllum rostellatum Lesquereux, pl. 443, pl. XXXI, fig. 8 (acc. to Janssen 1940).

* 1879-80 Lepidophyllum Mansfieldi Lesquereux, pp. 449-450, pl. LXIX, fig. 34 (acc. to Jongmans 1930).

1879-80 Lepidophyllum acuminatum, Lesquereux, pp. 450-451, pl. LXIX, fig. 37.

$\S 1927$ Lepidostrobophyllum maius, Hirmer, p. 193, textfig. 213.

? 1940 Lepidostrobophyllum acuminatum, Bell, pp. 127128, pl. VIII, figs. 7, 8 (both specimens incomplete).

p 1940 Lepidostrobophyllum majus, Janssen, pp. 3537, pl. X, fig. 1 (photograph of holotype of Lepidophyllum auriculatum), fig. 3 (photograph of holotype of Lepidophyllum rostellatum); non pl. X, fig. 2 (photograph of holotype of Lepidophyllum striatum).

1944 Lepidostrobophyllum majus, Bell, p. 96, pl. LIII, fig. 3.

1957 Lepidophyllum majus, Janssen, p. 63, fig. 45.

1957 Lepidophyllum lanceolatum, Janssen, p. 63, fig. 46.

1958 Lepidostrobophyllum majus, Langford, p. 99, fig. 183.

1958 Lepidostrobophyllum mansfieldi, Langford, p. 99, fig. 184. 
1962 Lepidostrobophyllum majus, Bell, p. 55, pl. XLVIII, fig. 5.

1963 Lepidostrobus auriculatus, Abbott, p. 101, pl. 28, fig. 3 (photograph of Lesquereux's holotype).

k 1963 Lepidostrobopsis missouriensis, Abbott, pp. 100101, pl. 28, figs. 1, 2, 4, 5, figs. 6, 7 (cuticle).

1963 Lepidostrobophyllum majus, Langford, p. 163, 164, figs. 738, 739, fig. 744 (?).

? 1963 Lepidostrobophyllum majus, Cridland et al., p. 75, pl. 17, fig. 11.

1966 Lepidostrobophyllum majus, Bell, pl. XXXVI, fig. 2.

1966 Lepidostrobophyllum, Gillespie et al., p. 24, 82, pl. 21, fig. 2.

1967 Lepidostrobophyllum majus, Tidwell, p. 22, pl. 1, fig. 2.

1968 Lepidostrobophyllum missouriense, Basson, pp. 5254, pl. 3, fig. 3.

1969 Lepidostrobophyllum (Lepidocarpon) majus, Darrah, p. 216, pl. 29, fig. 6.

1969 Lepidocarpon "majus", Darrah, p. 218, pl. 48, fig. 1; pl. 50, fig. 4.

1974 Lepidostrobophyllum auriculatum, Tidwell et al., p. 136, pl. 3, fig. 4.

1975 Lepidostrobophyllum sp., Tidwell, pl. 23, fig. 6 (same as Tidwell, 1974, pl. 3, fig. 4).

1976 Lepidostrobophyllum majus, Lyons and Chase, p. 409, 411, fig. 4B.

1977 Lepidocarpon major, Gastaldo, p. 136, fig. 10.

1978 Lepidostrobophyllum, Gillespie et al., p. 45, pl. 14, fig. 5 (same as Gillespie et al. 1966, pl. 21, fig. 2).

1984 Lepidostrobophyllum majus, Lyons, p. 511, fig. 10.B (same as Lyons and Chase 1976).

1995 Lycopsid sporangium from Lepidodendron, Willard et al., p. 82, fig. 8G.

1996 Lepidostrobophyllum majus, Cross et al., p. 404, fig. 23-6.2.

2005 Lepidostrobophyllum cf. majus, Dilcher et al., pp. 157-158, figs. 3.3., 3.12.1.

2005 Lepidostrobophyllum cf. majus, Dilcher and Lott, pl. 124, figs. 1, 4 (same as Dilcher et al. 2005, fig. 3.3), fig. 2 (same as Dilcher et al. 2005, fig. 3.12.1), figs. 3, 5-7.

2006 Lepidostrobophyllum majus, Wittry, p. 116, fig. 1.

p 2006 Lepidostrobophyllum lanceolatus, Wittry, fig. 2 (same as Janssen 1957, fig. 46); non p. 115, fig. 1 (= Lepidostrobophyllum oblongifolium), fig. 3 (same as Lepidostrobus oblongifolius Lesquereux 1870, pl. XXX, fig. 3).

Excludenda:

1925 Lepidophyllum majus, Noé, p. 14, pl. X, figs. 1, 2 (similar to the material figured as Lepidostrobophyllum moyseyi? by Bell 1938, pl. XCVIII, fig. 6, a synonym of Lepidostrobophyllum ovatifolium acc. to Crookall 1966).
REMARKS. Although the specimen figured by Bell (1944, pl. LIII, fig. 3) from locality 562 in New Brunswick is incomplete (it lacks the pedicel) and small (48 mm long and $15 \mathrm{~mm}$ wide), the identification seems reasonable. It is based on the broad lanceolate shape of the lamina, with its widest part in the lower two-thirds and the margins more or less parallel in this part, converging in the upper part to a slightly acuminate apex.

Bell (1962, pl. XLVIII, fig. 5) shows a typical example from the Minto coalfield of New Brunswick, probably of Bolsovian age. This specimen (GSC 956) shows a lanceolate lamina $100 \mathrm{~mm}$ long (without pedicel) and $14 \mathrm{~mm}$ at maximum width in the middle third, tapering gradually to a pointed apex. It also shows a prominent (about $2 \mathrm{~mm}$ wide) single vein.

STRATIGRAPHIC AND GEOGRAPHIC DISTRIBUTION. According to Crookall (1966), this species is rare in the Westphalian B and C (Duckmantian and Bolsovian) of Great Britain, and relatively common in the Westphalian $\mathrm{D}$ (Asturian). In the Iberian Peninsula, Wagner and ÁlvarezVázquez (2010) recorded it as occurring from Langsettian to Stephanian B (sensu stricto).

OCCURRENCE IN THE MARITIME PROVINCES, CANADA. CUMBERLAND BASIN (NOVA SCOTIA): Bell (1944): locality 1983 (one specimen without catalogue number). TYNEMOUTH CREEK (NEW BRUNSWICK): Bell (1944): locality 562 (GSC 9589). SYDNEY BASIN (NOVA SCOTIA): Bell (1966): locality 1306 (GSC 14925). MINTO COALFIELD (NEW BRUNSWICK): Bell (1940): locality 2616 (GSC 10466); locality 2832 (GSC 10363). Bell (1962): locality 1100 (GSC 956).

OCCURRENCE IN THE UNITED STATES. ALABAMA: Dilcher and Lott (2005), Dilcher et al. (2005). ILlinoIs: Lesquereux (1879-1880), Janssen (1940), Janssen (1957), Langford (1958), Abbott (1963), Darrah (1969), Gastaldo (1977), Wittry (2006). Indiana: Abbott (1963); Willard et al. (1995). KANSAS: Cridland et al. (1963). MASSACHUSETTS: Lyons and Chase (1976), Lyons (1984). MIssourI: Abbott (1963); Basson (1968). OHIO: Cross et al. (1996). UTAH: Tidwell (1967), Tidwell (1975), Tidwell et al. (1974). WEST VIRGINIA: Gillespie et al. (1966), Gillespie et al. (1978).

Lepidostrobophyllum morrisianum (Lesquereux 1880) Tenchov 1987

(Figs. 10b-d)

* 1879-80 Lepidophyllum Morrisianum Lesquereux, pp. 448-449, pl. LXIX, figs. 40, 41.

${ }^{*} \mathrm{v} 1944$ Lepidostrobophyllum fletcheri Bell, p. 96, pl. XLIX, fig. 1 (refigured here as Fig.10d), fig. 2 (see Fig. 10c), fig. 3 (holotype - refigured here as Fig. 
10b), fig. 4. (to Lepidostrobophyllum morrisianum acc. to Crookall 1966).

1958 Lepidostrobophyllum morrisianum, Langford, p. 96, fig. 177.

v 1959 Lepidophyllum tieghemi, Jongmans in Wagner, p. 399 (a misidentification of Sigillariostrobus tieghemii Zeiller).

T 1966 Lepidophylloides morrisianus, Crookall, p. 532, pl. CII, figs. 9, 10; text-fig. 152C (copy of Lesquereux's 1879 original figures of type material).

$\S 1987$ Lepidostrobophyllum morrisianum, Tenchov, p. 67, Tab. XXVII, fig. 11.

v 1995 Lepidophylloides morrisianus, Álvarez-Vázquez, pp. 232-233, lám. 78, fig. 4 .

T 2006 Lepidostrobophyllum morrisianus, Wittry, p. 116, fig. 1, fig. 2 (same as Lesquereux 1879, pl. LXIX, fig. 41).

v 2010 Lepidophylloides morrisianus, Wagner and Álvarez-Vázquez, p. 258, 266.

DESCRIPTION. Lamina lanceolate, apparently thin, lacking in consistency, with cordate base and straight or slightly convex margins tapering gradually to a pointed apex. Simple vein strongly marked, wide (about $0.5 \mathrm{~mm}$ at base), reaching into the tip of the leaf, and bordered by a groove on both sides. Dimensions: $17-20 \mathrm{~mm}$ long and 6-7.5 $\mathrm{mm}$ at maximum width (in lower fourth of leaf length); ratio $\approx 2.7$. Pedicel wedge-shaped, 6-7 mm long and 3-4 $\mathrm{mm}$ broad at the widest point (always narrower than the lamina).

REMARKS. Lepidostrobophyllum fletcheri Bell (1944, p. 96, pl. XLIX, figs. 1-4) was placed in synonymy with the distinctive species Lepidostrobophyllum morrisianum by Crookall (1966, p. 532), who also transferred the latter to the genus Lepidophylloides, which includes detached leaves of arborescent lycopsids. However, we agree with Tenchov (1987, p. 67) that the illustrations of both Lesquereux (1879) and Bell (1944) show this species to represent a sporophyll composed of a stalk, pedicel and lamina. The species should thus be included in Lepidostrobophyllum (as was done by Bell).

COMPARISONS. This species is clearly distinguished by the lamina having a lower part lacking consistency, a cordate base, and a pointed apex.

STRATIGRAPHIC AND GEOGRAPHIC DISTRIBUTION. Lepidostrobophyllum morrisianum is a rare element of European Westphalian floras. It is long-ranging, having been recorded from Langsettian to Asturian substages.
OCCURRENCE IN THE MARITIME PROVINCES, CANADA. CUMBERLAND BASIN (NOVA SCOTIA): Bell (1944): locality 999 (GSC 8215 + GSC 8589 + GSC 9508 + GSC 9802 + one piece without catalogue number - together with Annularia ramosa and Eusphenopteris cf. neuropteroides).

OCCURRENCE IN THE UNITED STATES. ILLINOIS: Lesquereux (1879-1880), Langford (1958), Wittry (2006).

Family Diaphorodendraceae

Genus Diaphorodendron DiMichele 1985 emend. DiMichele and Bateman 1992

TYPE. Diaphorodendron vasculare (Binney 1862) DiMichele 1985.

DIAGNOSIS (after DiMichele and Bateman 1992 pars; only those characters applicable to adpressions are stated here). "Leaf bases developed as leaf cushions with a distinct leaf scar. Parichnos confined to foliar scar. Cushions only slightly protruding from stem surface, higher than wide in tangential view on axes of all diameters. Lower keel generally with several distinct plications; upper keel may have one to several plications. Ligule pit shallow, narrow, and tending to be vertically oriented, opening just above the leaf scar".

REMARKS. DiMichele (1985) instituted this genus on the basis of anatomical characters that are only partially reflected by adpressions. DiMichele and Bateman (1992) emended the generic description and produced a reconstruction of the growth form of the tree Diaphorodendron scleroticum. They also provided a diagrammatic drawing of mega- and microsporangiate parts of strobili - Achlamydocarpon varius - that are found in association with Diaphorodendron and the related genus Synchysidendron.

Ligule pits are not normally preserved as distinct markings in the adpression material, and a keel with its plications is also not always clearly visible. However, the latter is a character that should probably be considered of specific importance rather than generic. Thus the distinguishing characters of species based on adpression material are the relative proportion of leaf cushions, the presence of a distinct leaf scar with its vascular-bundle scar and flanking parichnos, and the absence of infrafoliar parichnos. W.A. DiMichele (personal communication, 2013) also considers that the interareas in Diaphorodendron are "fissure-like", often with multiple grooves or wrinkles. This contrasts with Synchysidendron, in which the interareas are much smoother, reflecting the fact that they are cellular expansion zones. 


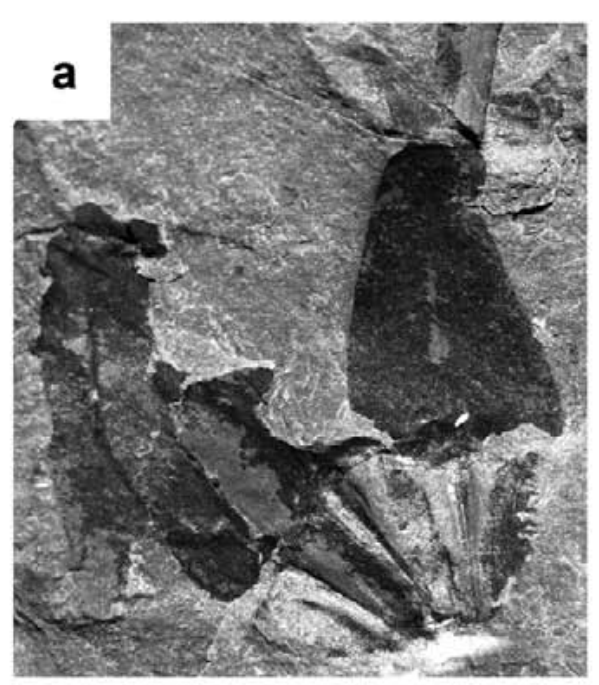

Diaphorodendron decurtatum (Dawson 1868) comb. nov.

(Figs. 11a-b, 12a-h)

* 1868 Lepidodendron decurtatum Dawson, p. 487, figs. 170A, A1 (refigured here as Figs. 11a-b).

p 1873 Lepidodendron Sternbergii, Dawson, p. 45, pl. VI, figs. 42-42b, fig. 43; non pp. 22-23, pl. VI, figs. 4445 (possibly Bergeria dilatata).

* 1879-80 Lepidodendron Andrewsii Lesquereux, p. 389, pl. LXIV, fig. 6.

p 1899 Lepidodendron scutatum, White, pp. 198-200, pl. XLV, fig. 4; pl. LIV, fig. 5 (drawing); pl. LV, figs. 1-2a; non pl. LXXII, fig. 4 (leafy branches).

1903 Lepidodendron dichotomum, Arber, p. 20, pl. I, figs. 1, 2.

* 1904 Lepidodendron Grigorievi Zalessky, pp. 92-93, pl. IV, figs. 2, 2a.

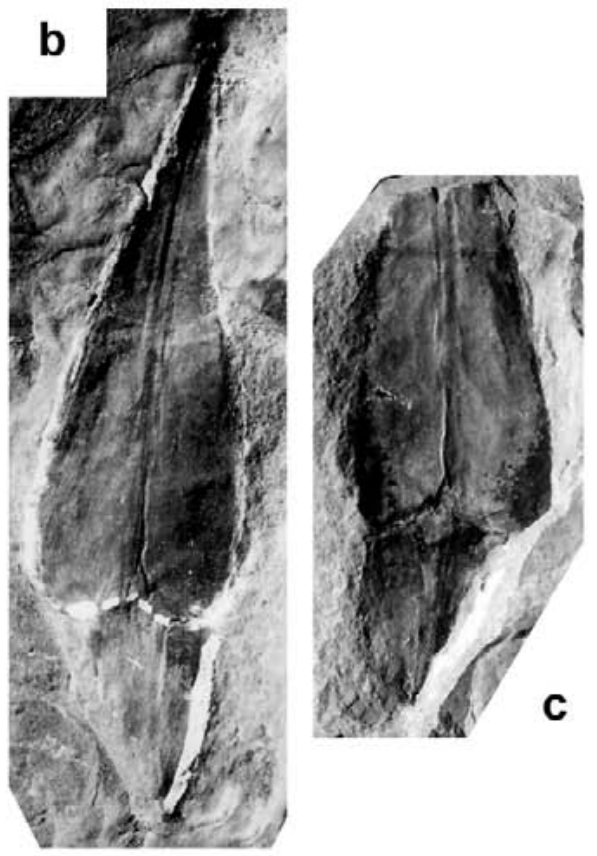

1914 Lepidodendron dichotomum, Arber, p. 402, pl. 29, fig. 36.

*p 1922 Lepidodendron loricatum Arber, pp. 201-205 (excluding synonymy), pl. 13, fig. 27, fig. 28 (same as Arber 1914, pl. 29, fig. 36), fig. 29, fig. 30 (same as Lepidodendron dichotomum, Arber 1903, pl. I, fig. 2), figs. 31, 32; non pl. 13, figs. 33-35 (= Lepidodendron arberi acc. to Thomas 1970); non pl. 13, figs. 36, 37 (to be compared with Lepidodendron fusiforme acc. to Thomas 1970).

? 1925 Lepidodendron latifolium, Noé, p. 14, pl. VII, fig. 4; pl. VIII, fig. 3 (poorly figured).

1925 Lepidodendron Wortheni, Noé, p. 14, pl. VIII, fig. 2. ${ }^{*} \mathrm{v} 1938$ Lepidodendron dichotomum var. bretonensis

Figure 10. (a) Lepidostrobophyllum hastatum (x 3). Sporophylls composed of a wedge-shaped pedicel and a subtriangular lamina, on the reverse side of Bell's holotype of Lepidodendron dichotomum var. bretonensis. Origin: Sydney coalfield, Nova Scotia, shore east of Schooner Pond Cove at most westerly crop of McRury seam (locality 513).

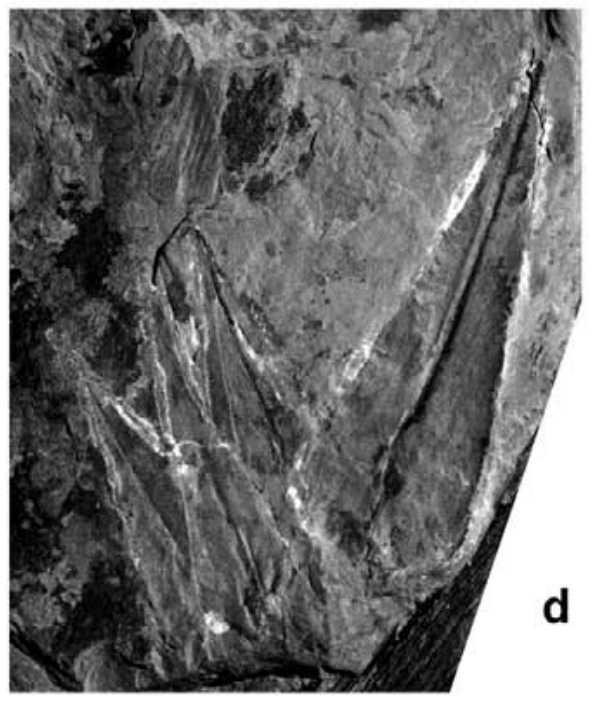
(b) Lepidostrobophyllum morrisianum (x 3). GSC 8589. Holotype of its synonym Lepidostrobophyllum fletcheri Bell showing the lanceolate lamina with slightly convex margins tapering into a pointed apex and cordate base (all characteristics of Lesquereux's species). Previously figured in Bell (1944, pl. XLIX, fig. 3). Origin: Maccan River, Springhill, about 0.8 kilometres west of Mapleton (locality 999). (c) Lepidostrobophyllum morrisianum (x 3). GSC 9802. Paratype of Lepidostrobophyllum fletcheri showing the wide, strongly marked midvein. Previously figured in Bell (1944, pl. XLIX, fig. 2). Origin: same as for 10b (locality 999). (d) Lepidostrobophyllum morrisianum (x 3). GSC 9508. Paratype of Lepidostrobophyllum fletcheri figured in Bell (1944, pl. XLIX, fig. 1). Origin: same as for 10b (locality 999). Repository: Geological Survey of Canada, Ottawa. 
Bell, pp. 92-93, pl. XCV, figs. 5-8, fig. 9 (holotype - partially refigured here in Figs. 12f, g, h); pl. XCVI, fig. 1 (enlargement of part of holotype); pl. XCVII, fig. 4.

1940 Lepidodendron dichotomum, Bell, p. 122, pl. VII, fig. 4.

v 1944 Lepidodendron dichotomum var. bretonensis Bell, $\mathrm{p}$. 89, pl. XLV, fig. 3 (partially refigured here as Figs. $12 \mathrm{~b}, \mathrm{c})$.

p 1947 Lepidodendron subdichotomum, Němejc, pl. I, fig. 7; non pp. 57-59, pl. I, fig. 8 (= ?).

1950 Lepidodendron aff. dissitum, Gómez de Llarena, p. 76, lám. XVII.

1958 Lepidodendron obovatum, Langford, p. 67, figs. $108,109$.

? 1958 Lepidodendron loricatum, Langford, p. 69, fig. 112 (leaf cushions of larger size).

* 1958 Lepidodendron wilmingtoni Langford, p. 71, figs. 117-121.

* 1960 Lepidodendron crofti Stockmans and Willière, p. 306, 308, pl. XIII, figs. 1-8; pl. XIV, figs. 1-5.

* 1960 Lepidodendron paucipunctatum Stockmans and Willière, p. 306, 308, pl. XII, figs. 10, 11, fig. 12
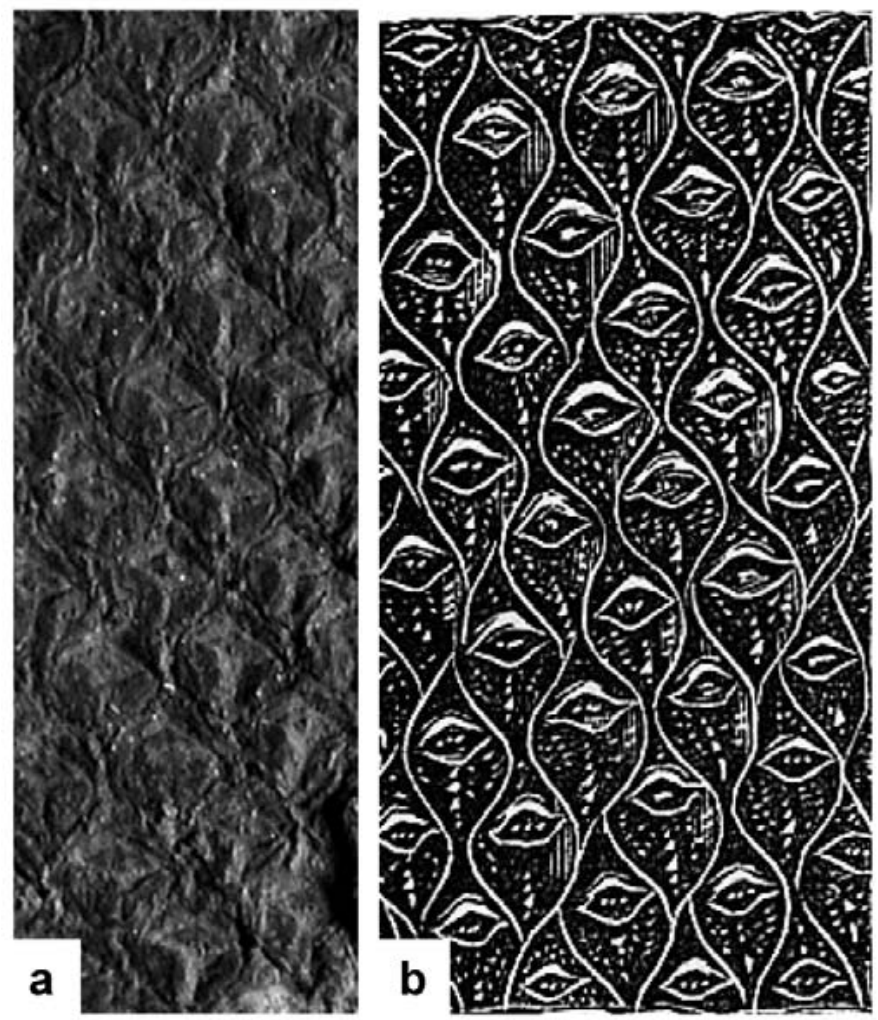

Figure 11. Diaphorodendron decurtatum. (a) Photograph of part of Lepidodendron decurtatum holotype (x 3). Photo: A.W. Howell, Redpath Museum, Montreal. (b) Enlargement (x 3) of the original drawing in Dawson (1868). (with ulodendroid branch scar); pl. XIV, fig. 7.

p 1962 Lepidodendron bretonense Bell, pp. 53-54, pl. XLVII, fig. 5; pl. XLVIII, fig. 4; non pl. XLVII, fig. 6 (decorticated - comparable with "Lepidodendron" rimosum); non pl.

XLVIII, fig. 6 (specimen with elongate, fusiform cushions comparable with "Lepidodendron" rimosum); non pl. XLIX, fig. 2 (small leafy branches from the same locality as others figured as Lepidodendron pictoense).

1963 Lepidodendron sp., Langford, p. 153, figs. 712, 713 (included by Wittry, 2006 in Lepidodendron andrewsii).

p 1964 Lepidodendron loricatum, Crookall, pp. 243-244, pl. LXIV, figs. 6-9; text-fig. 79 (same as Arber 1922, pl. 13, fig. 32); non pl. LXI, fig. 1 (?).

p 1964 Lepidodendron obovatum, Crookall, pl. LX, fig. 3; non pp. 239-242, pl. LX, fig. 4 (= Lepidodendron bellii); non text-fig. 77B (drawing of leaf cushion); non text-fig. 78 (tree reconstruction of Hirmer 1927, fig. 200).

1964 Lepidodendron sp., Crookall, p. 303, pl. LXXII, figs. 5, 5 a.

1965 Lepidodendron dissitum, Stockmans and Willière, pl. XV, figs. 4-5a.

v 1965 Lepidodendron cf. scutatum, Wagner, p. 144, pl. 37, fig. 80.

p 1966 Lepidodendron bretonense Bell, p. 42, 44, pl. XX, fig. 4; pl. XXI, fig. 5; non pl. XX, fig. 5

(longer cushions with keel crossed by distinct transverse wrinkles).

1968 Lepidodendron andrewsi, Abbott, pp. 6-7, pl. 12, fig. 12 (cushion diagram); pl. 18, fig. 3.

1968 Lepidodendron scutatum, Abbott, pp. 7-8, pl. 12, fig. 11 (cushion diagram); pl. 18, fig. 2.

k 1970 Lepidodendron subdichotomum, Thomas, p. 162, text-figs. 10E-H.

1972 Lepidodendron decurtatum, Alison and Carroll, p. 117 (reference to Dawson's holotype).

? 1975 Lepidodendron obovatum, Boneham, p. 96, pl. 1, fig. 1 (poorly figured).

1980 Lepidodendron bretonense, Zodrow and McCandlish, p. 80, pl. 116, fig. 1; pl. 118, fig. 1 (poorly preserved), fig. 2.

p 1980 Lepidodendron pictoense, Zodrow and McCandlish, p. 81, pl. 117, figs. 1-3; non pl. 120, fig. 3 (although difficult to judge from illustration, the large cushion size and the diamond-shaped leaf scars exclude assignment to Diaphorodendron decurtatum; probably Lepidodendron aculeatum).

p 1980 Lepidophloios laricinus, Zodrow and McCandlish, pl. 124, fig. 1; non p. 82, pl. 123, fig. 2 (resembles Lepidodendron bellii), fig. 3 (= Lepidophloios laricinus).

1982 Lepidodendron aculeatum, DiMichele in Eggert 
and Phillips, p. 20, pl. 2, fig. B.

? 1982 Lepidodendron lanceolatum, Oleksyshyn, pp. 1314 (excluding synonymy), fig. 7B (upside down poorly figured).

? 1985 Lepidodendron cf. aculeatum, Gastaldo, p. 292, pl. 3 , fig. A (poorly figured).

v 1985 Lepidodendron dissitum, Wagner and Talens, pp. 437-442, pl. 1, figs. 1-1a, fig. 2 (same as Wagner, 1965, pl. 37, fig. 80); pl. 2, figs. 1-2a; pl. 3, figs. 1-3.

1985 Lepidodendron bretonense, Wnuk, pp. 169-177, pl. 2, figs. 7-10; pl. 3, figs. 12, 13 (tree trunks); textfig. 13 (drawing).

1987 Lepidodendron loricatum, Tenchov, p. 59, pl. XXI, figs. 5-7.

1995 Diaphorodendron sp., Willard et al., p. 81, 82, figs. $8 \mathrm{~A}-\mathrm{D}$.

? 1996 Diaphorodendron (L.) scleroticum, Calder et al., p. 293, fig. 8c (difficult to judge from illustration).

1996 Lepidodendron obovatum, Cross et al., fig. 23-5.1.

1997 "Lepidodendron" cf. dissitum, Wagner and Lyons, p. 261, 263, pl. I, figs. 4, 5 .

2005 Diaphorodendron bretonense (Bell) Bashforth, pp. 36-38, pl. 2, figs. 1-4, 7, 8; text-fig. 22A.

2006 Lepidodendron andrewsii, Wittry, p. 106, fig. 1 (photograph of holotype), fig. 2 (copy of Lesquereux's 1880 drawing), fig. 3.

p 2006 Lepidodendron aculeatum, Wittry, fig. 8; non pp. 104-105, figs. 1-7 (Lepidodendron aculeatum).

2009 Lepidodendron, Taylor et al., p. 283, fig. 9.32.

v 2010 Diaphorodendron bretonense, Wagner and Álvarez-Vázquez, p. 273, 276, 282, 284, 309, 311, 316.

DESCRIPTION (based on all the Canadian material available). Leaf cushions small, contiguous in medium-sized specimens, and with narrow interareas, up to $0.7 \mathrm{~mm}$ wide in the older ones. They are subrhomboidal, asymmetrical, higher than broad, with maximum width at about the middle. Lateral angles rounded, apex and base acute, very slightly inflected. Dimensions: $5-8 \mathrm{~mm}$ long and 3-4 mm broad; ratio $=1.7-2$. Keel below the leaf scar faintly marked, unornamented or with short, transverse wrinkles. Leaf scars large in relation to cushion size, placed in the upper third of the cushion and occupying two thirds or more of cushion width. Leaf scars rhomboidal, broader than long, with upper and lower angles rounded and lateral angles acute, with three foliar prints (leaf trace and parichnos), more or less of equal size, in line, and situated in the lower part of the leaf scar. Dimensions: $2-3 \mathrm{~mm}$ long and $2.5-3.5 \mathrm{~mm}$ broad; ratio $\approx 0.8$. Ligule pit placed just above the leaf scar.

REMARKS. Dawson (1868) figured and described a very fragmentary bark imprint from Bolsovian(?) strata of the Pictou coalfield in Nova Scotia as a new species,
Lepidodendron decurtatum. Dawson's drawing is reproduced here as Fig. 11b. Part of a photograph of the type, which is in the Dawson collection in the Redpath Museum, McGill University, Montreal, is reproduced here in Fig. 11a. It confirms the accuracy of Dawson's drawing.

The characters described by Dawson (1868) include leaf cushions separated by shallow (narrow?) furrows, of rhombic ovate shape, obliquely acuminate below, nearly as broad as long, with transverse wrinkles, particularly on median line, with a rhombic leaf scar that contains three cicatricules ("vascular points" in Dawson's description). Although the holotype of Lepidodendron decurtatum is fragmentary, its characters wholly agree with those recorded by Bell (1962) for Lepidodendron bretonense, a taxon which Bell (1938) had introduced previously as Lepidodendron dichotomum var. bretonensis from upper Asturian and lower Cantabrian strata of the Sydney coalfield, Breton Island, Nova Scotia. Bell $(1938,1962)$ did not refer to Lepidodendron decurtatum, a species that has not been mentioned since its introduction by Dawson (1868). Additional material of Lepidodendron bretonense was illustrated by Bell (1966) from the Minto coalfield in New Brunswick.

Specimens recorded by Bell (1944) as Lepidodendron dichotomum var. bretonensis from the Cumberland Basin, Nova Scotia, are all fragmentary and sometimes poorly preserved, e.g., the partly decorticated specimen refigured here in Figs. 12b-c. The holotype of Lepidodendron bretonense (Bell 1938, pl. XCV, fig. 9; pl. XCVI, fig. 1) from the Sydney Basin is refigured here (Figs. 12f, $\mathrm{g}, \mathrm{h}$ ) alongside a single specimen from the Guardo coalfield, northwestern Spain (Figs. 12d-e), testifying to the widespread occurrence of Diaphorodendron decurtatum.

Bell (1938) noticed the close resemblance of Lepidodendron dichotomum var. bretonensis with Lepidodendron andrewsii and Lepidodendron grigorievii. He noted that the only distinguishing character between Lepidodendron dichotomum var. bretonensis and Lepidodendron andrewsii is the presence of a keel below the leaf scar in some Canadian specimens of the former taxon. Both Lepidodendron andrewsii and Lepidodendron grigorievii are here regarded as likely synonyms of Diaphorodendron bretonense, and thus of Diaphorodendron decurtatum. Bell (1962) also compared Lepidodendron bretonense with the similar species Lepidodendron loricatum (originally described as Lepidodendron dichotomum by Arber 1903, 1914) and with Lepidodendron subdichotomum. The latter is a poorly characterized species (see Jongmans 1929 , p. 317). According to Němejc (1947, p. 58), both species are possible synonyms of Lepidodendron dissitum, a species described from the Westphalian of Belgium (see Stockmans 1935), and recorded later from the Stephanian of northwestern Spain (Stockmans and Willière 1965). The Spanish records of Lepidodendron dissitum are discussed at length by Wagner and Talens (1985), who compared, 


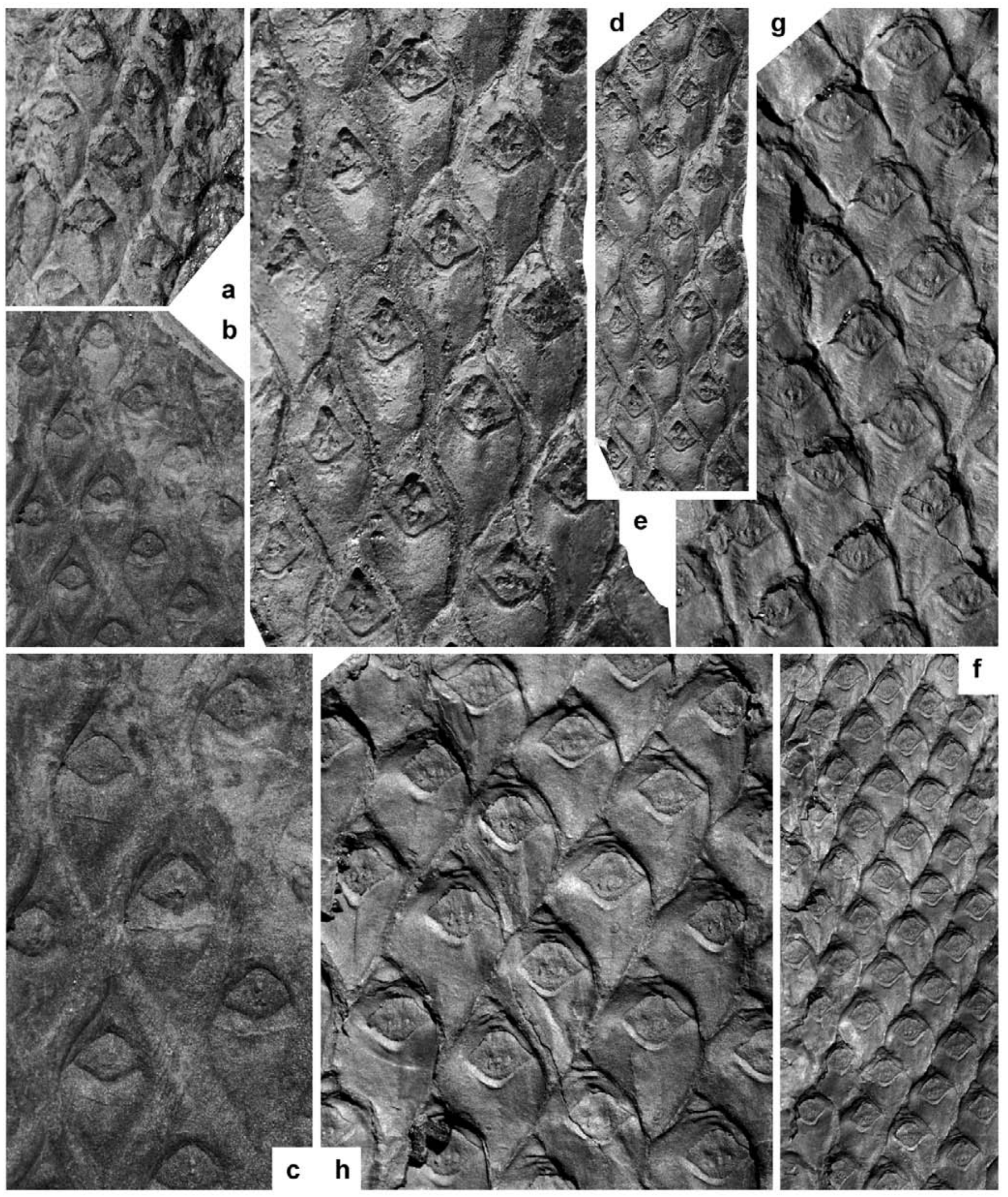


but did not synonymize, this species with Lepidodendron bretonense. Bashforth (2005) transferred Lepidodendron bretonense to Diaphorodendron, which is correct in view of the absence of infrafoliar parichnos. However, he failed to refer to Lepidodendron dissitum and seems to have overlooked the comparison made by Wagner and Talens (1985). Lepidodendron dissitum also shows the absence of infrafoliar parichnos, which suggests that it should be assigned to Diaphorodendron. The material from northwestern Spain attributed to Lepidodendron dissitum comes mainly from Stephanian strata (up to and including Stephanian B), but also includes some remains of Asturian age. Wagner and Álvarez-Vázquez (2010, p. 316) identified the Spanish material as Diaphorodendron bretonense, but chose not to synonymize it with Lepidodendron dissitum, a species originally described from the Bolsovian of Belgium. The latter was redescribed by Stockmans (1935), who figured specimens which are quite similar to Diaphorodendron bretonense. However, slight differences are apparent. "Lepidodendron" dissitum from Belgium shows slightly more elongate leaf cushions, which in some specimens also display relatively wide, wrinkled interareas. Sauveur's (1848, pl. LIX, fig. 3) illustration (a drawing) of the holotype of Lepidodendron dissitum suggests poor preservation. Unfortunately, the specimen cannot be located and may have been lost (C. Prestianni, personal communication, 2011). However, it is likely that the specimens illustrated by Stockmans (1935) from Belgium were assigned correctly to Sauveur's species. In view of the (admittedly rather slight) differences noted, the present writers have opted for now to keep "Lepidodendron" dissitum separate from Diaphorodendron decurtatum. A more detailed study of the former species would be helpful.

Wagner (1965) tentatively identified material from the Stephanian in northwest Spain as Lepidodendron scutatum, but mentioned that Gómez de Llarena (1950) had used the name Lepidodendron dissitum. The latter name was adopted also by Stockmans and Willière (1965) for Spanish material.
Wagner and Talens (1985) accepted the latter action, but compared with the material illustrated by White (1899) as Lepidodendron scutatum. In view of the poor illustration of the holotype of Lepidodendron scutatum (Lesquereux 1879 , pl. LXIII, figs. 6, 6c), this taxon should be regarded as species dubia pending restudy of the type. The description by Lesquereux (1880, p. 369-370) seems to suggest that it might belong to Bergeria rather than Diaphorodendron. White (1899, p. 199) already expressed doubts as to the conspecifity of his material with the various specimens illustrated by Lesquereux.

Wnuk (1985) recorded several specimens as Lepidodendron bretonense from the Anthracite Field of Pennsylvania, U.S.A. Wnuk's photographs show the right size and shape of leaf cushions for Diaphorodendron decurtatum, as well as a proper leaf scar in the top half of the cushion. In a drawing, Wnuk (1985, text-fig. 13) indicated the presence of foliar parichnos markings but no infrafoliar ones. The same drawing also shows the transverse wrinkles in the lower part of the leaf cushions, occupying the area of a keel that is not evident.

Two species described by Stockmans and Willière (1960) from the lower Westphalian of Belgium, Lepidodendron croftii and Lepidodendron paucipunctatum, are here regarded as synonyms of Diaphorodendron decurtatum. Stockmans and Willière (1960) only provided a brief diagnosis of these two species, which were not even compared with one another.

COMPARISONS. Lepidodendron dichotomum is similar to Diaphorodendron decurtatum in the size and shape of its leaf cushions, as well as in the position of its leaf scar. However, Lepidodendron dichotomum possesses infrafoliar parichnos (see the photograph of the holotype by Němejc 1946, pl. 1, figs. 1-3a - attributed, surprisingly, to Lepidodendron mannebachense by Opluštil 2010, fig. 5, who refigured the specimen). Infrafoliar parichnos are absent in Diaphorodendron decurtatum.

Figure 12. (previous page) (a) Diaphorodendron decurtatum (x 3). GSC 8547. Origin: Maccan River, Springhill, about $1 / 2$ mile west of Mapleton (locality 999). (b) Diaphorodendron decurtatum (x 3). GSC 8666. Partially decorticated remain figured previously as Lepidodendron dichotomum var. bretonensis by Bell (1944, pl. XLV, fig. 3). Origin: same as for 12a (locality 999). (c) Diaphorodendron decurtatum. Enlargement (x 6) of specimen in 12b. Not numbered locality. Repository: Geological Survey of Canada, Ottawa. (d) Diaphorodendron decurtatum (x 3). Specimen from northwestern Spain, figured for direct comparison with Bell's holotype. Origin: Ocejo Formation, Tejerina outlier, northern León (locality 1181). (e) Diaphorodendron decurtatum (x 6). Same specimen as in 12d. Repository: Centro Paleobotánico, Real Jardín Botánico de Córdoba. (f) Diaphorodendron decurtatum. GSC 3348 (x 3). Specimen figured as Lepidodendron dichotomum var. bretonense by Bell (1938, pl. XCV, fig. 9; pl. XCVI, fig. 1 - holotype of Lepidodendron bretonense). Origin: Sydney coalfield, Nova Scotia, shore east of Schooner Pond Cove at most westerly crop of McRury seam (locality 513). (g) Diaphorodendron decurtatum. GSC 3348. Enlargement (x 6) of an area in the upper part of Bell's holotype of Lepidodendron bretonense showing the faintly marked keel below the leaf scar crossed by short, transverse wrinkles. Origin: same as for $12 \mathrm{f}$ (locality 513). (h) Diaphorodendron decurtatum. GSC 3348. Enlargement (x 6) of another part of Bell's holotype. Note the absence of wrinkles. Origin: same as for $12 \mathrm{f}$ (locality 513). Repository: Geological Survey of Canada, Ottawa. 
"Lepidodendron" dawsonii has slightly larger, more elongate, fusiform leaf cushions four to five times longer than wide. Also, the leaf scars are rhomboidal, with a nearly equal length/breadth ratio or with a slightly greater width, and a location just above the middle of the cushion. Infrafoliar parichnos are clearly absent in "Lepidodendron" dawsonii.

STRATIGRAPHIC AND GEOGRAPHIC DISTRIBUTION. The holotype of Lepidodendron decurtatum is from Bolsovian(?) strata of the Pictou coalfield, Nova Scotia. The type material of Lepidodendron andrewsii is from the uppermost Asturian or lowermost Cantabrian strata of Mazon Creek, Illinois. Lepidodendron wilmingtonii was based on Mazon Creek material from the Wilmington area. The type material of Lepidodendron grigorievi comes from the $\mathrm{C}_{3}{ }^{1}$ level of the Donetz Basin, of late Moscovian (late Asturian to early Cantabrian) age. The type specimens of Lepidodendron croftii and Lepidodendron paucipunctatum are from upper Westphalian A (upper Langsettian) strata of the Campine (Kempen) coalfield, Belgium. Diaphorodendron decurtatum has been recorded in Great Britain as Lepidodendron loricatum, Lepidodendron dichotomum and Lepidodendron obovatum, collectively from Langsettian to Bolsovian strata (see Crookall 1964; Thomas 1970). Bashforth (2005) recorded Diaphorodendron bretonense from Bolsovian strata of Newfoundland. In the Iberian Peninsula, Wagner and Álvarez-Vázquez (2010) recorded the species (as Diaphorodendron bretonense) from Asturian to Stephanian B strata.

OCCURRENCE IN THE MARITIME PROVINCES, CANADA. CUMBERLAND BASIN (NOVA SCOTIA): Bell (1944): locality 999 (GSC 7506 + GSC 8666 + GSC 8547 - together with Lepidostrobophyllum hastatum + GSC 8548 - also with Lepidostrobophyllum hastatum + GSC 8549). SYDNEY BASIN (NOvA scotia): Bell (1938): locality 513 (GSC 3307 + GSC 3345 + GSC 3348 - holotype of Lepidodendron bretonense); locality 720 (GSC 3427); locality 906 (GSC 3998); GSC 4491. Bell (1966): locality 504 (GSC 15059). Zodrow and McCandlish (1980). Calder et al. (1996). PICTOU COALFIELD (Nova SCOTIA): Dawson (1868 - holotype). Bell (1940): locality 2657 (GSC 10927). Bell (1962): locality 977 (GSC 809); locality 1079 (GSC 812). Alison and Carroll (1972 holotype). NEWFOUNDLAND: Bashforth (2005).

OCCURRENCE IN THE UNITED STATES. ALABAMA: Gastaldo (1985). ILLINoIs: Lesquereux (1879-1880), Noé (1925), Langford (1958, 1963), Wittry (2006), Taylor et al. (2009). IndiANA: Abbott (1968), Boneham (1975), DiMichele in Eggert and Phillips (1982), Willard et al. (1995). MIssourI: White (1899). OHIO: Abbott (1968), Cross et al. (1996). PENnsylvania: Oleksyshyn (1982), Wnuk (1985). WEST VIRGINIA: Wagner and Lyons (1997).
Family Flemingitaceae

Genus Bergeria Presl in Sternberg 1838

TYPE. Bergeria acuta Presl in Sternberg 1838, herein considered a synonym of Bergeria dilatata (Lindley and Hutton 1831) comb. nov. The type of the genus remains the holotype of Bergeria acuta.

DIAGNOSIS. Arborescent lycopsid stems covered with spirally arranged, rhomboidal leaf cushions, longer than broad, contiguous or separated by narrow grooves, and without a differentiated leaf scar. Leaves linear-lanceolate, entire, single-veined.

REMARKS. This lycopsid genus encompasses specimens that lack a well-differentiated leaf scar. Leaves are attached with the entire leaf width, and situated in the top part of the leaf cushion. This configuration has been described as a "false leaf scar" by Chaloner and Boureau in Boureau (1967, p. 533), who asserted that a proper leaf scar would correspond to the marking left after shedding the leaf (caducous habit). However, we regard the caducous habit as unlikely, and consider the shape and size of the leaf scar to be due to the position of the leaf with regard to the leaf cushion and to the kind of leaf base, which may be either narrow or more laterally extensive.

The name Bergeria has usually been applied to partially decorticated lycopsid stems with lepidodendroid leaf cushions. Indeed, Fischer (1905b) stated that Bergeria represented a particular state of preservation ("Erhaltungszustand"). He figured and described material with subepidermal preservation, lacking the outline of the leaf scars. However, it seems that he confused partially decorticated remains with better-preserved specimens not possessing a proper leaf scar and with the leaves attached at a single point at the top of a leaf cushion (Fischer 1905b, fig. 6). These are the false leaf scars as defined by Chaloner and Boureau in Boureau (1967). It is this confusion that made Fischer include the type material of Bergeria acuta, possessing a "false leaf scar", with other remains that were in a partially decorticated condition.

We interpret the type material of Bergeria acuta (photographed by Kvaček and Straková 1997, pl. 2, figs. 3-4) as being well-preserved stem fragments that are not decorticated; they show the outline of leaf cushions with an irregular, poorly defined leaf scar in the top part of the cushion. These observations were confirmed by S. Opluštil (personal communication, 2013) after re-examining Presl's material in the Narodni Museum in Prague. A specimen displaying the same characters as Bergeria acuta and showing attached leaves was figured and described by Lindley and 
Hutton (1831, pl. 7, fig. 2) as Lepidodendron dilatatum (Fig. 13). Although Lindley and Hutton illustrated their species only with a drawing, its characters, including the shape and attachment of long leaves, are clear. Lepidodendron dilatatum takes precedence over Bergeria acuta. The correct name of the species therefore becomes Bergeria dilatata (Lindley and Hutton 1831) comb. nov., though the nomenclatural type of the genus remains the holotype of Bergeria acuta.

The same taxon was identified by Thomas (1968) as Ulodendron landsburgii. Thomas mentioned the lack of proper leaf scars. The type material of Ulodendron landsburgii (Kidston 1893, pl. III, figs. 9-10a) was refigured by Crookall (1964, pl. LXIII, figs. 1, 2) under another name, Lepidodendron ophiurus, a misidentification. One of these specimens (Kidston, 1893, pl. III, fig. 10; Crookall 1964, pl. LXIII, fig. 1) shows a large branch scar such as appears also in Ulodendron majus (Lindley and Hutton 1831, pl. 5) and Ulodendron minus (Lindley and Hutton 1831, pl. 6). Evidently, more than one arborescent lycopsid of Pennsylvanian age possessed large branch scars, either singly or in vertical rows. This implies that the scars alone cannot serve to diagnose a genus. We do not agree with the interpretation of Ulodendron by Thomas $(1967,1968)$ and consider Ulodendron sensu Thomas (i.e., excluding the type material of Ulodendron) to be congeneric with Bergeria, as explained above.

DiMichele (1980) noted the similarities between the permineralized genus Paralycopodites and the adpression genus Ulodendron (sensu Thomas; i.e., Bergeria), but maintained these two genera separately due to the absence of anatomical characters for Ulodendron. Pearson (1986) synonymized both Ulodendron sensu Thomas and Paralycopodites with Anabathra, a genus based on a single specimen showing both adpression and permineralized preservation. The holotype of Anabathra pulcherrima originated from the uppermost Tournaisian/Visean of Allanbank, Berwickshire, Scotland. It was restudied by Pearson (1986), who determined on the basis of its wood anatomy, leaves and megasporangia that it should be regarded as conspecific with Paralycopodites brevifolius. Since the latter species is the type of Paralycopodites, Pearson regarded this genus as synonymous with Anabathra. On the other hand, DiMichele and Phillips (1994, p. 59) considered the type material of Anabathra as being too fragmentary to justify this synonymy and reinstated Paralycopodites. They restricted Anabathra to the type material. This may be questionable. However, these two conflicting opinions do not affect the nomenclature of adpression material.

Bergeria dilatata (Lindley and Hutton 1831) comb. nov. (Figs. 13, 14a-h, 16g-h)

* 1831 Lepidodendron dilatatum Lindley and Hutton, p. 27, pl. 7, fig. 2 (Fig. 13 herein) (attributed to Lepidodendron ophiurus by Zeiller 1888, and tentatively included in Lepidodendron acutum by Němejc 1947).

* 1831 Lepidodendron gracile Lindley and Hutton, p. 30, pl. 9, figs. 1, 2 (included in Lepidodendron ophiurus by Kidston 1890).

1831 Lepidodendron Sternbergii, Lindley and Hutton, pp. 15-21, pl. 4.

* 1838 Bergeria acuta Presl in Sternberg, p. 184, Taf. XLVIII, figs. 1a, $1 \mathrm{~b}$.

* 1838 Bergeria angulata Presl in Sternberg, p. 184, Taf. LXVIII, fig. 17 (to Lepidodendron acutum acc. to Němejc 1947).

* 1838 Bergeria marginata Presl in Sternberg, p. 184, Taf. LXVIII, fig. 16 (to Lepidodendron acutum acc. to Němejc 1947).

* 1838 Bergeria quadrata Presl in Sternberg, p. 184, Taf. LXVIII, fig. 19 (to Lepidodendron acutum acc. to Němejc 1947).

* 1838 Bergeria rhombica Presl in Sternberg, p. 184, Taf. LXVIII, fig. 18 (to Lepidodendron acutum acc. to Němejc 1947).

* 1854 Lepidodendron Haidingeri Ettingshausen, p. 55, Taf. 22; Taf. 23, figs. 1, 2 (same as Lepidodendron acutum acc. to Kidston 1911).

* 1860 Lepidodendron Oweni Wood, p. 239, pl. 5, fig. 1.

1873 Lepidodendron tetragonum, Dawson, pp. 28-29, pl. V, figs. 39, 39a.

p 1873 Lepidodendron Sternbergii, Dawson, pp. 22-23, pl. VI, figs. $44-45$; non p. 45 , pl. VI, figs. $42-42 \mathrm{~b}$ (maybe Diaphorodendron decurtatum), fig. 43 (poorly figured).

* 1879-80 Lepidodendron lanceolatum Lesquereux, p. 369, pl. LXIII, figs. 3-5a (to Lepidodendron lycopodioides acc. to Arber 1922, and Lepidodendron acutum acc. to Němejc 1947).

*? 1879-80 Lepidodendron Scutatum Lesquereux, p. 369, pl. LXIII, figs. 6-6c.

1879-80 Lepidodendron rhombicum, Lesquereux, p. 382, pl. LXII, figs. 4, 4a; LXIV, fig. 18.

1884 Lepidodendron (Bergeria) marginatum, Lesquereux, p. 784, pl. CVII, fig. 3.

* 1893 Lepidodendron Landsburgii Kidston, pp. 338-339, pl. III, figs. 9-10b (transferred to Ulodendron by Thomas 1968, and to Anabathra by Pearson 1986).

1899 Lepidodendron lanceolatum, White, pp. 192-195, pl. LIII, figs. 2, 2a.

1909 Lepidodendron similis Kidston in Jongmans, p. 174, 201, 215 (nomen nudum).

1911 Lepidodendron simile Kidston, pp. 137-138.

p 1937 Lepidodendron obovatum, Jongmans, p. 403, pl. 23, fig. 55; non p. 404, pl. 24, fig. 61 (= Lepidodendron bellii).

1937 Lepidodendron ophiurus, Jongmans, p. 397, 409, pl. 


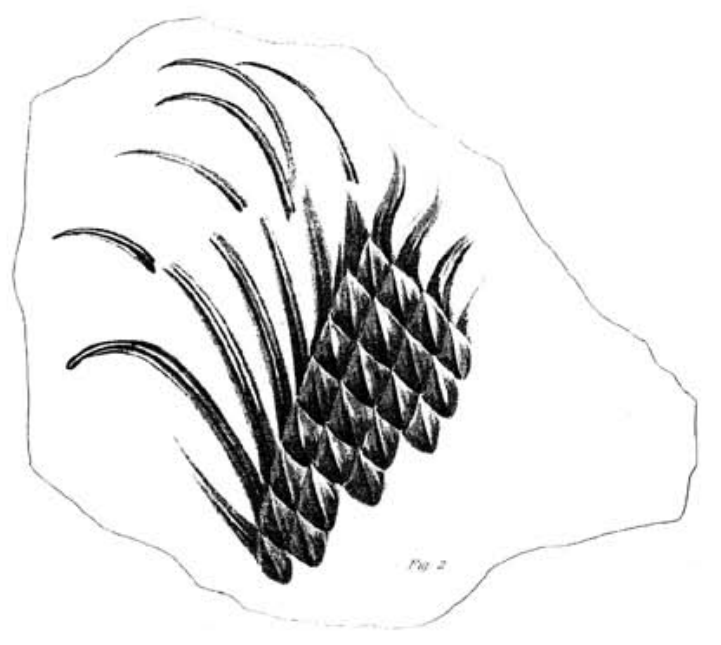

Figure 13. Copy (at reduced size) of original figure of Lepidodendron dilatatum published by Lindley and Hutton (1831, pl. 7, fig. 2).

15, figs. 23-24; pl. 31, figs. 94-97.

? 1938 Lepidodendron lycopodioides, Bell, pp. 93-94, pl. XCVI, fig. 2, fig. 3 (presence or absence of leaf scars not clear from illustrations); pl. XCVII, figs. 1-3 (small leafy branches).

p 1940 Lepidodendron ophiurus, Bell, p. 123, pl. VII, figs. 5, 7; non pl. VII, fig. 6 (a single leaf cushion with leaf attached).

v p 1944 Lepidodendron lanceolatum, Bell, pp. 88-89, pl. XLVIII, fig. 3 (small branches with terminal strobili, referable to Flemingites russelianus - see later).

? 1949 Lepidodendron aculeatum, Arnold, pp. 160-161, pl. II, figs. 1, 3, 4 .

1949 Lepidodendron lanceolatum, Arnold, pp. 165-167, pl. V; pl. VI, figs. 4-6 (included in Lepidodendron acutum by Bell 1962).

p 1949 Lepidodendron ophiurioides? Arnold, pl. IV, fig. 5; non pp. 162-165, pl. III, fig. 4 (Lepidodendron ophiurioides); non pl. IV, figs. 1-3 (Lepidodendron ophiurioides).

1949 Lepidodendron vestitum, Arnold, pp. 168-169, pl. II, fig. 5.

p 1964 Lepidodendron ophiurus, Crookall, pl. LXI, fig. 4 (branchlets); pl. LXIII, figs. 1,2 (Lepidodendron landsburgii syntypes); ? pl. LXI, fig. 9 (cannot be judged with certaincy from the illustration); non pp. 287-294, pl. LXII, fig. 5 (resembles Lepidodendron ophiurus); non pl. LXX, fig. 7 (maybe "Lepidodendron" volkmannianum); $\mathrm{pl}$. LXXIII, fig. 4 (terminal part of branch with attached strobilus - difficult to identify beyond "Lepidodendron" sp.); text-fig. 93 (copy of
Brongniart's original figure of Lepidodendron ophiurus).

1966 Lepidodendron pictoense (= ? L. ophiurus), Bell, p. 10, pl. IV, fig. 13.

1966 Lepidodendron ophiurus, Bell, pl. XX, fig. 1 (same as Bell 1940, pl. VII, fig. 7).

k 1968 Ulodendron landsburgii (Kidston) Thomas, pp. 426-428, text-figs. A-D (referred to Anabathra landsburgii by Pearson 1986, p. 280).

? 1969 Lepidodendron lanceolatum, Darrah, p. 181, pl. 32, fig. 1.

1978 Lepidodendron cf. wortheni, Gillespie et al., p. 52, pl. 12, fig. 2.

? 1978 Lepidodendron with attached Lepidophylloides, Gillespie et al., p. 45, 52, pl. 12, fig. 4; pl. 13, figs. 3, 4, 5 (small branches with attached leaves; difficult to judge from illustrations).

? 1985 Lepidodendron acutum, Gillespie and Rheams, p. 200, pl. III, fig. 9 (small branch; presence or absence of leaf scars is unclear).

? 1985 Lepidodendron acutum, Gillespie and Crawford, p. 250, pl. I, fig. 3 (poorly figured).

? 1985 Lepidodendron cf. rimosum, Gillespie and Crawford, p. 250, pl. I, fig. 6 (poorly figured).

v 1995 Ulodendron acutum (Presl) Álvarez-Vázquez, p. 218, lám. 73; lám. 74, figs. 1, 2; lám. 75, fig. 1; lám. 76 , figs. 1,6 .

1997 Lepidodendron acutum, Kvaček and Straková, p. 28, pl. 2, figs. 3, 4 (holotype of Bergeria acuta); p. 34, pl. 4, fig. 3 (holotype of Bergeria angulata); p. 100, pl. 33, fig. 5 (holotype of Bergeria marginata); p. 126, pl. 45, fig. 4 (holotype of Bergeria quadrata); p. 130, pl. 46, fig. 4 (holotype of Bergeria rhombica).

v 2010 Ulodendron acutum, Wagner and Álvarez-Vázquez, p. 257, 262, 264, 266, 270, 307, pl. XI, fig. 2.

DESCRIPTION. Leaf cushions flat, smooth, contiguous or separated by narrow grooves, obovate, with the broadest part in the upper third or upper half of cushion, straight or slightly inflected acuminate base, acute apex, and rounded lateral angles. Dimensions: $7-15 \mathrm{~mm}$ long and 2-4 mm broad; ratio $\approx 3.5$. Keel absent or only faintly marked, smooth or (occasionally) with a few faint, short transverse lines. A small, irregular scar marks the position of the leaf base at the top of the cushion. Parichnos absent. Leaves linearlanceolate, slightly curved near the base, single-veined, at least three or four times longer than the cushions, and inserted at $45-50^{\circ}$ angle. Branches dichotomously forked at angles of $30-45^{\circ}$ (measurements based on more examples than the few Canadian specimens).

REMARKS. Although Bell (1944, p. 80) mentioned the presence of Lepidodendron lanceolatum at several localities in the Cumberland Basin, he only figured one specimen (his pl. XLVIII, fig. 3 - later included by Bell 1962 in Lepidodendron 

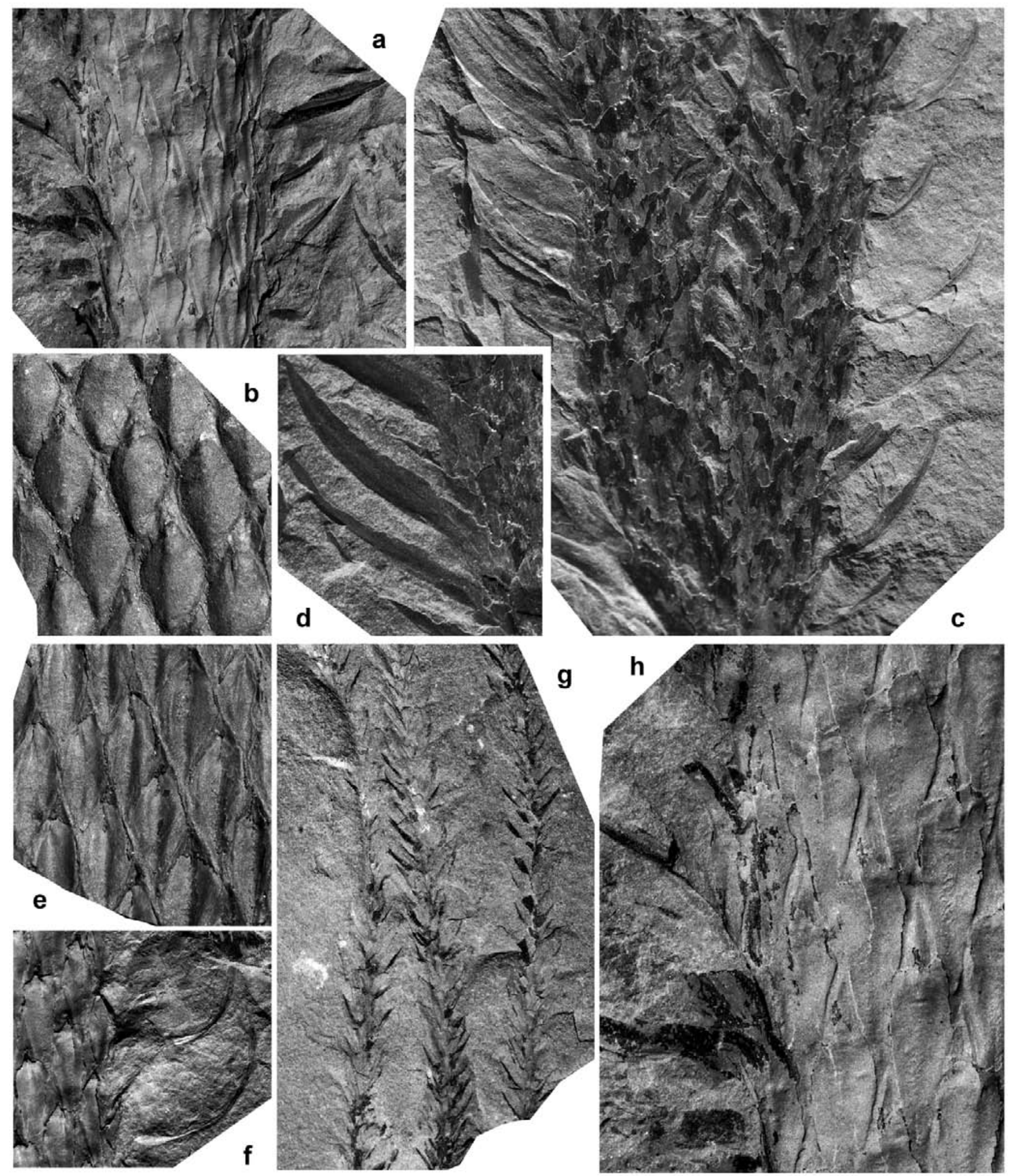

Figure 14. (a) Bergeria dilatata (x 3). Origin: Spicer Cove, section 11, bed 7 (locality 1341). (b) Bergeria dilatata (x 3). Origin: locality 3995. (c) Bergeria dilatata (x 3). Two leafy shoots dichotomously forked at a narrow angle. Origin: Minas Basin shore, mouth of Moose River (locality 1411). (d) Enlargement (x 6) of part of the specimen in 14c showing the slightly curved insertion of leaves. (e) Bergeria dilatata (x 3). Origin: Springhill, borehole from no 2 mine (locality 1496). (f) Bergeria dilatata (x 3). Another example of the insertion of leaves on a small branch. Origin: same as for $14 \mathrm{c}$ (locality 1411). (g) Terminal branchlets showing the slightly curved leaves, inserted at c. $45^{\circ}$. Origin: Spicer Cove, section 11 , below bed 28 (locality 1342). (h) Enlargement $(x 6)$ of part of 14a, showing a faintly marked keel crossed by short, transverse lines. Repository: Geological Survey of Canada, Ottawa. 
pictoense), which is from the Minas Basin, Nova Scotia (Bell's locality 1406, Moose River). Another specimen from the same locality (cited as 3100 but apparently the same as locality 1406) was figured by Bell (1966, pl. IV, fig. 13) and recorded as Lepidodendron pictoense. Crookall (1964, p. 290) referred Bell's (1944) specimen to Lepidodendron ophiurus, as were those determined as Lepidodendron lycopodioides by Bell (1938) and Lepidodendron ophiurus by Bell (1940). Němejc (1947) included Lepidodendron lanceolatum in Lepidodendron acutum, a species synonymized herein with Bergeria dilatata.

The specimen in Bell (1944, pl. XLVIII, fig. 3) shows thin ultimate branches with attached leaves and terminal strobili. This material is closely similar to that figured here (Figs. $14 \mathrm{c}, \mathrm{d}, \mathrm{f}$ and $16 \mathrm{a}-\mathrm{b}, \mathrm{g}-\mathrm{h}$ ) from locality 1411, also at Moose River (Minas Basin). Bell (1944) compared his material with Lepidodendron simile, which we consider to be a synonym of Bergeria dilatata, and with Lepidodendron lycopodioides, a species that Němejc (1947) regarded as synonymous with Lepidodendron selaginoides. However, "Lepidodendron" selaginoides possesses fusiform, elongate leaf cushions with linear, very short leaves that are different from those of the Canadian specimens.

Zeiller (1888) and Kidston $(1890,1891)$ both referred Lepidodendron dilatatum (now Bergeria dilatata) to Lepidodendron ophiurus. The holotype of Lepidodendron ophiurus (Brongniart 1822, pl. IV, figs. la, b - drawings reproduced in Crookall 1964, text-fig. 93) shows three small leafy branches with rhomboidal leaf cushions that display a well-marked, unornamented keel. The enlargement figured by Brongniart (1822, fig. 1b) shows definite (rhomboidal) leaf scars with a single central marking, suggesting the absence of parichnos. Quite apart from the presence or absence of parichnos, the clearly differentiated leaf scars exclude the assignment of Lepidodendron ophiurus to Bergeria.

The synonymy list cites the many names applied to this species, both as synonyms and misidentifications. Bergeria dilatata is well represented in the Westphalian fossil record, allowing for a full description of adpression characters. Although our description is based primarily on the Canadian specimens, we also compared these with a large collection (several hundred specimens) from the Peñarroya Basin of early Westphalian age in southwestern Spain.

COMPARISONS. The presence of almost flat, smooth leaf cushions with small, irregular scars at or near the top of the cushion, and the absence of parichnos make Bergeria dilatata a distinctive species.

Bergeria worthenii has the field above and below the leaf scar ornamented with coarse, transverse, discontinuous wrinkles.

STRATIGRAPHIC AND GEOGRAPHIC DISTRIBUTION. The holotypes of both Lepidodendron dilatatum and Lepidodendron gracile originated in the Low Main coal seam, Felling Colliery, Durham coalfield, corresponding to lower Westphalian B (lower Duckmantian) according to Ramsbottom et al. (1978). The type material of Bergeria acuta, Bergeria angulata, Bergeria marginata, Bergeria quadrata and Bergeria rhombica all came from the Nýrany Member, Kladno Formation, central Bohemia, of Asturian/ early Cantabrian age. The holotypes of Lepidodendron lanceolatum and Lepidodendron scutatum came from the Clinton Coal, Missouri, probably of early Asturian age. In Great Britain, the species has been recorded (under various names) throughout the Westphalian. According to Wagner and Álvarez-Vázquez (2010), this species (recorded as Ulodendron acutum) ranges from Langsettian to Asturian in the Iberian Peninsula.

OCCURRENCE IN THE MARITIME PROVINCES, CANADA. CUMBERLAND BASIN (NOVA SCOTIA): Bell (1944): locality 1053 (one piece with leafy branches without catalogue number); locality 1080 (GSC 9854 + GSC 9865 + GSC 9866 - together with Laveineopteris polymorpha and Calamites suckowii); locality 1340 (three pieces, without catalogue number, with small leafy branches); locality 1341 (one piece - with Zeilleria avoldensis); locality 1342 (one piece leafy branches); locality 1344 (two pieces - leafy branches); locality 1375 (one piece - leafy branch); locality 1401 (six pieces - with Dorycordaites palmaeformis); locality 1406 (GSC 9913 + two pieces without catalogue number - also Flemingites russelianus); locality 1430 (three pieces - small leafy branches); locality 1439 (small leafy branch); locality 1491 (two pieces - poorly preserved); locality 1496 (one poorly preserved specimen associated with rootlets + two pieces associated with Calamites suckowii); locality 1497 (three pieces - fragmentary) locality 1498 (two pieces leafy branches); locality 1983 (one piece); locality 2989 (two pieces); GSC 8995. MINAS BASIN (NOVA SCOTIA): Bell (1944): locality 77 (GSC 332); locality 1411 (five pieces - also Flemingites russelianus); locality 2261 (without catalogue number). Bell (1966): locality 3100 (GSC 14929). SYDNEY BASIN (NOVA SCOTIA): Bell (1938): locality 514 (GSC 3305); locality 537 (GSC 3315); locality 922 (GSC 3999); locality 923 (GSC 4003); locality 929 (GSC 3978). MINTO COALFIELD (NEW BRUNSWICK): Bell (1940): locality 1107 (GSC 10449); locality 2645 (GSC 10401); locality 2839 (GSC 10448). Bell (1966): locality 1107 (GSC 10449 — same as Bell, 1940).

OCCURRENCE IN THE UNITED STATES. ALABAMA: Gillespie and Rheams (1985); GEORGIA: Gillespie and Crawford (1985). ILLINOIs: Lesquereux (1879-1880), Darrah (1969). KENTUCKY: Lesquereux (1879-1880). MICHIGAN: Arnold (1949). MIssouri: Lesquereux (1879-1880, 1884), White (1899). PenNSYlvania: Lesquereux (1879-1880, 1884), Wood (1860). WEST VIRGINIA: Jongmans (1937), Gillespie et al. (1978). 
Bergeria worthenii (Lesquereux 1866) comb. nov.

(Figs. 15a-e)

? 1848 Lepidodendron elongatum, Sauveur, pl. LX, fig. 1 (acc. to Zeiller 1888).

* 1866 Lepidodendron Worthenii Lesquereux, p. 452, pl. XLIV, figs. 4, 5.

* 1875 Sagenaria microstigma Feistmantel, p. 213, Taf. XLI, fig. 2.

* 1879-80 Lepidodendron Brittsii Lesquereux, p. 368, pl. LXIII, figs. 1-2 (acc. to Kidston 1911, p. 146).

1879-80 Lepidodendron Worthenii Lesquereux, p. 388, pl. LXIV, figs. 8-9.

1899 Lepidodendron Brittsii, White, pp. 188-192, pl. LII, figs. 1-3a; pl. LIII, figs. 1, 1a; pl. LIV, figs. 1-2.

v 1938 Lepidodendron wortheni, Bell, p. 94, pl. XCVI, figs. 4-7.

1938 Ulodendron Wortheni, Renier and Stockmans in Renier et al., p. 63, pl. 11; text-fig. 13.

T 1940 Lepidodendron wortheni, Janssen, p. 13, pl. I, fig. 3 (photograph of holotype - obverse side), fig. 4 (holotype - reverse side).

v 1944 Lepidodendron wortheni, Bell, pp. 90-91, pl. XLVII, fig. 2 (refigured here as Fig. 15e), fig. 4 (detail in Fig. 15a); pl. L, fig. 2; pl. LIV, fig. 4 (refigured in part as Fig. 15b).

T 1957 Lepidodendron wortheni, Janssen, p. 43, fig. 19 (photograph of holotype).

1958 Lepidodendron brittsi, Langford, p. 67, figs. 105107.

1959 Lepidodendron wortheni, Canright, p. 28, pl. 1, fig. 4.

1963 Lepidodendron wortheni, Wood, p. 36, pl. 2, fig. 1 (greatly reduced, but probably attributed correctly).

T 1964 Lepidodendron wortheni, Crookall, pp. 275-279, pl. LXI, figs. 2, 2a, 7, text-figs. 89A-C (copy of Lesquereux's original figures).

v 1966 Lepidodendron wortheni, Bell, pl. XI, fig. 3 (same as Bell 1944, pl. XLVII, fig. 4).

1990 Lepidodendron wortheni, DiMichele and Beall, $\mathrm{p}$. 247, fig. 7.

T 2003 Lepidodendron worthenii, Laveine et al., p. 586, 587,600 , pl. VII, figs. 1, 2 (photographs of obverse and reverse sides of holotype).

T 2006 Lepidodendron worthenii, Wittry, p. 108, fig. 1 (after Lesquereux 1866), figs. 2, 3.

v 2010 Ulodendron worthenii, Wagner and ÁlvarezVázquez, p. 262, 264, 266, 273, 307, pl. XI, figs. 3, 3a.

Excludenda:

1925 Lepidodendron Wortheni, Noé, p. 14, pl. VIII, fig. 2 (= Diaphorodendron decurtatum).

1977 Lepidodendron wortheni, Leary and Pfefferkorn, pp. 6-7, pl. 1, fig. 1; text-fig. 4A (excluded because of the presence of leaf scars and infrafoliar parichnos).

1978 Lepidodendron cf. wortheni, Gillespie et al., p. 46, 52, 53, pl. 11, fig. 7 (= Lepidodendron aculeatum).

1985 Lepidodendron cf. wortheni, Gillespie and Crawford, p. 252, pl. II, fig. 2 (= Lepidodendron aculeatum).

DESCRIPTION. Leaf cushions contiguous, varying in outline from narrowly fusiform to obovate, with maximum width in the upper third; base elongate, acuminate, apex acute, lateral angles rounded. Dimensions: $10-13 \mathrm{~mm}$ long and $1.5-3 \mathrm{~mm}$ broad; ratio 5 to 7 . No proper leaf scars, but a narrow irregular, transversely oval to punctiform scar in the upper third of cushion and ocupying almost the entire cushion width. Keel absent; field above and below the leaf scar occupied by relatively coarse, transverse, discontinuous wrinkles. Ligule pit situated at $0.5-1 \mathrm{~mm}$ above the leaf scar. Leaves linear-lanceolate, inserted at a narrow angle, rigid in aspect, in excess of $30 \mathrm{~mm}$ length, with an acuminate apex and a prominent vein.

REMARKS. Several specimens were figured as Lepidodendron wortheni by Bell (1944). Some of these (e.g., Bell 1944, pl. XLVII, fig. 2) are similar to the type material from Murphysboro, Illinois (see photographs in Janssen 1940, 1957, and Laveine et al. 2003). Bell's specimens show almost total cover of leaf cushions by transverse wrinkles, leaving only a narrow, transversely oval strip of leaf scar. A ligule pit is visible immediately above the leaf scar. (Bell 1944 , p. 90 , mentions a punctiform ligule scar at $0.25 \mathrm{~mm}$ above the "leaf trace", referring to his pl. XLVII, fig. $4-\mathrm{a}$ detail reproduced here as Fig. 15 a). Two of the specimens figured by Bell show branches with attached leaves: one of these (Bell 1944, pl. L, fig. 2) represents a thin distal branch with spreading leaves; the other (Bell 1944, pl. XLVII, fig. 2; partially reproduced here as Fig. 15 e) represents a larger branch.

COMPARISONS. Although various species belonging to different genera also show abundant transverse wrinkles covering most of the leaf cushions, Bergeria worthenii may be distinguished by large cushions with a generally convex surface, as well as by the absence of a proper leaf scar.

The similar Namurian (Serpukhovian) species Lepidodendron lossenii also possesses fusiform leaf cushions with short, transverse and irregularly placed wrinkles in the field above and below the leaf scar. However, its leaf cushions are always small and have a length/breadth ratio of $\approx 10$.

White (1937) mentioned the general similarity of the Mississippian species Lepidodendron wedingtonense with Lepidodendron worthenii and its synonym Lepidodendron brittsii. However, Lepidodendron wedingtonense shows small, transversally elongate leaf scars with three relatively big cicatricules. This distinguishes it clearly from Bergeria. 

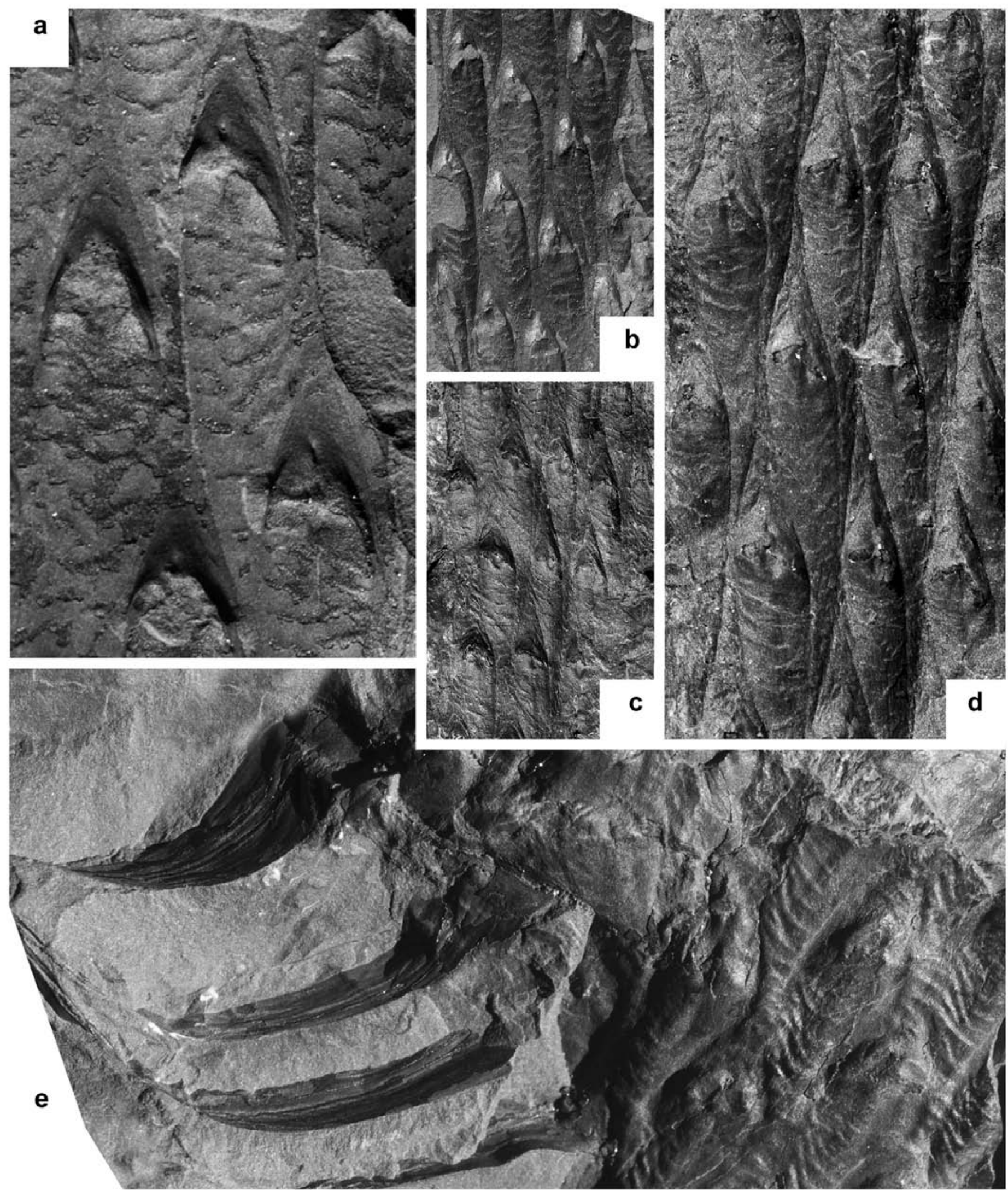
STRATIGRAPHIC AND GEOGRAPHIC DISTRIBUTION. The type material of Bergeria worthenii comes from Murphysboro, Illinois, U.S.A., and is of early Asturian age (Peppers 1996, p. 61-62). Crookall (1964) recorded the species throughout the Westphalian of Great Britain, being rare in Westphalian A (Langsettian) and B (Duckmantian), and fairly common in Westphalian D (Asturian). According to Josten (1991) the species ranges from Langsettian to Bolsovian in the Ruhr district of western Germany.

OCCURRENCE IN THE MARITIME PROVINCES, CANADA. CUMBERLAND BASIN (NOVA SCOTIA): Bell (1944): locality $666=1141$ (GSC $10232-$ part and counterpart); locality 1039 (GSC 9027 + GSC 9301); locality 1498 (cf. three pieces without catalogue number). Bell (1966): locality $666=1141$ (GSC 10232 - same as Bell, 1944). SYDNEY BASIN (NOVA SCOTIA): Bell (1938): locality 914 (GSC 4098); locality 922 (GSC 4063); locality 923 (GSC 3514 + GSC 4084).

OCCURRENCE IN THE UNITED STATES. ILLINOIS: Lesquereux (1866), Lesquereux (1879-1880), Janssen (1940, 1957), Langford (1958), Crookall (1964), Laveine et al. (2003), Wittry (2006). Indiana: Canright (1959), Wood (1963), DiMichele and Beall (1990). MIssourI: Lesquereux (1879-80), White (1899).

Genus Flemingites Carruthers 1865 emend. Brack-Hanes and Thomas 1983

TYPE. Flemingites gracilis Carruthers 1865

DIAGNOSIS (after Brack-Hanes and Thomas 1983). "Sporophylls in spirals on the cone axis. Axis with exarch vascular bundle surrounded by cortical zones. Sporangium with narrow attachment along its length to adaxial surface of sporophyll pedicel. Ligule on adaxial surface of pedicel distal to sporangium. Lateral parts of lamina extending beyond sporangium. Abaxial keel along length of pedicel. Pedicel extends distally to upturned lamina and downturned heel. Cones bisporangiate with apical microsporangia and basal megasporangia. Megaspores either Lagenicula- or
Lagenoisporites-type. Microspores of Lycospora-type with narrow equatorial flange and usually smooth proximal surface, distal surface variable in ornament".

Flemingites russelianus (Binney 1871) Brack-Hanes and Thomas 1983

(Figs. 16a-b, d-f)

* p 1871 Lepidostrobus Russelianus Binney, p. 51, Pl. IX, figs. 1, 1a; non pl. IX, figs. 2, 2a (= Lepidostrobus dubius Binney, synonym of Flemingites gracilis acc. to Chaloner 1953).

* 1871 Lepidostrobus Hibbertianus Binney, p. 55, Pl. X, figs. 2-2b (acc. to Chaloner 1953).

v p 1944 Lepidodendron lanceolatum, Bell, pp. 88-89, pl. XLVIII, fig. 3 (strobili associated with leafy branches attributed here to Bergeria dilatata - see synonymy list of this species).

1949 Lepidostrobus sp., Arnold, pp. 172-173, pl. VII, figs. 1, 3, 4 (acc. to Chaloner 1953).

1952 Ulostrobus Goodei, Stockmans and Willière, Pl. E, fig. 1 (associated with Ulodendron goodei); pl. F, figs. 1, 1a, fig. 2 (with Ulodendron goodei), figs. 3-5a (see synonymy list of Bergeria dilatata).

1953 Lepidostrobus russelianus, Chaloner, p. 277 (emended diagnosis), text-figs. 13-16 (megaspores), 17A-E (microspores).

T 1966 Lepidostrobus russelianus, Crookall, pp. 500-501, text-fig. 147 (copy of Binney 1871).

$\$ 1983$ Flemingites russelianus, Brack-Hanes and Thomas, p. 132.

v 1995 Flemingites russelianus, Álvarez-Vázquez, p. 222, lám. 74, fig. 3; lám. 75, fig. 2; lám. 77.

DESCRIPTION. Cylindrical strobilus up to $60 \mathrm{~mm}$ long and $15 \mathrm{~mm}$ broad, tapering only in the top part to end in a rounded apex. Sporophylls arranged in a low-angle spiral, rigid in aspect and closely adpressed. Sporophyll lamina lanceolate, with acute apex and a relatively broad, prominent central vein. Dimensions: up to $10 \mathrm{~mm}$ long and $1.3 \mathrm{~mm}$ wide.

REMARKS. The association of Flemingites russelianus with Lepidodendron acutum (now Bergeria dilatata) has

Figure 15. (previous page) (a) Bergeria worthenii. GSC 10232. Detail ( $\mathrm{x} 9$ ) showing the position of the ligule pit above false leaf scars. Previously figured by Bell (1944, pl. XLVII, fig. 4; 1966: pl. XI, fig. 3). Origin: borehole, Springhill (locality 1141 = 666). (b) Bergeria worthenii (x 3). GSC 10232. Part of the specimen figured in Bell (1944, pl. LIV, fig. 4). Counterpart of specimen figured in 15a. Origin: same as for 15a (locality $1141=666)$. (c) Bergeria worthenii $(\mathrm{x} 3)$. Reverse side of the piece with a leafy banch (GSC 9301) figured in Bell (1944, pl. L, fig. 2). Origin: Springhill, $\mathrm{n}^{\circ} 2$ mine, waste dump (locality 1039). (d) Enlargement (x 6) of the same specimen. (e) Bergeria worthenii. GSC 9027. Detail (x 5) of the specimen figured in Bell (1944, pl. XLVII, fig. 2), showing attached leaves. Origin: same as for 15c (locality 1039). Repository: Geological Survey of Canada, Ottawa. 


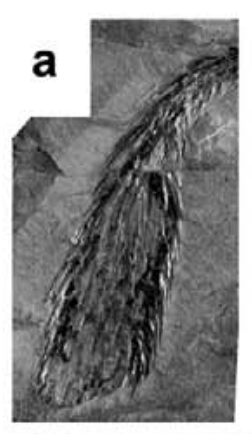

\section{b}
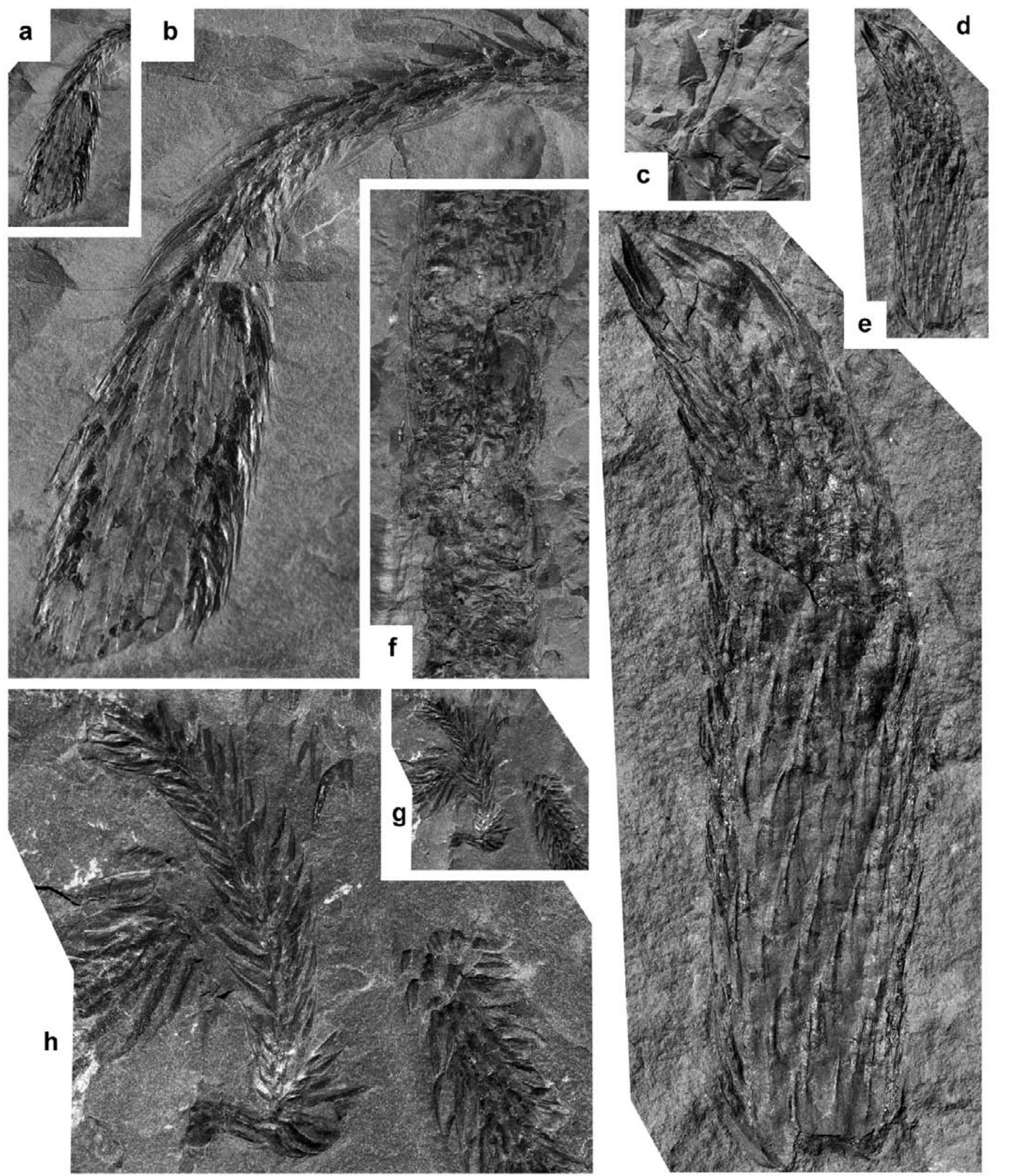
been generally recognized (e.g., Chaloner 1953; ÁlvarezVázquez 1995). All the Canadian specimens included in this species are associated with branches of Bergeria dilatata. None of these display sporangial contents.

The incomplete strobilus figured by Jongmans (1937, pl. 15, fig. 25) as Lepidostrobus cf. goodei, most likely belongs to Flemingites russelianus, a conclusion reinforced by its association with Bergeria dilatata (recorded by Jongmans as Lepidodendron ophiurus).

STRATIGRAPHIC AND GEOGRAPHIC DISTRIBUTION. Binney's material comes from Airdrie, Lanarkshire, Scotland, from rocks of Duckmantian age. Chaloner (1953) and Crookall (1966) recorded the species from Langsettian to Bolsovian in Great Britain. In the Peñarroya Basin, southwestern Spain, it occurs in upper Langsettian and upper Duckmantian/lower Bolsovian strata (Álvarez-Vázquez 1995, 2000), often in association with specimens of the relatively common Bergeria dilatata.

OCCURRENCE IN THE MARITIME PROVINCES, CANADA. CUMBERLAND BASIN (NOVA SCOTIA): locality 1053 (GSC 9951 - fragmentary + GSC 9952 + GSC 9953 - together with Senftenbergia plumosa); locality 1406 (GSC 9913 - strobili associated with leafy branches of Bergeria dilatata + one specimen without catalogue number); locality 1411 (two pieces - together with leafy branches of Bergeria dilatata); locality 1496 (one specimen, part and counterpart, associated with Bergeria dilatata, Calamites suckowii and Dorycordaites palmaeformis).

OCCURRENCE IN THE UNITED STATES. MICHIGAN: Arnold (1949).

Family Sigillariaceae

Genus Sigillaria Brongniart 1822

TYPE. Sigillaria scutellata Brongniart 1822

REMARKS. Sigillaria is a diverse genus of arborescent, generally unbranched, Carboniferous lycopsids, less often with an unequal dichotomous apex. The leaf scars are arranged in vertical rows or spirally, and may be contiguous or more or less distant from one another. Their shape is hexagonal to subcircular, generally showing three cicatricules, the lateral ones (parichnos) larger than the central marking (vascular trace). Traditionally, the genus has been divided into two major groups, i.e., with ribbed stems (Eusigillariae) and non-ribbed (Subsigillariae). Each group contains two subdivisions. The Eusigillariae comprise the (sub)genus Favularia (ribs divided into hexagonal compartments, with leaf scars occupying nearly the entire width - e.g., Sigillaria hexagona) and (sub)genus Rhytidolepis (ribs separated by straight or slightly flexuous furrows; leaf scars in vertical rows, occupying all or part of rib width - e.g., Sigillaria scutellata). The Subsigillariae were subdivided into Clathraria (no ribs, leaf scars more or less contiguous, separated by oblique furrows - e.g., Sigillaria brardii) and Leiodermaria (no ribs, leaf scars distant and interfoliar surface ornamented - e.g., Sigillaria reticulata). These divisions are rarely used nowadays. We use Sigillaria in the wide sense.

Sigillaria hexagona (Schlotheim 1820) Brongniart 1828a (Figs. 17c-e, g)

1820 Palmacites hexagonatus Schlotheim, Taf. XV, fig. 1. $\$$ 1828a Sigillaria hexagona Brongniart, p. 65, 172.

* 1837 Sigillaria hexagona Brongniart, pl. 155.

p 1868 Sigillaria elegans, Dawson, p. 432, figs. 161 B2B3; non fig. 161B (reconstruction); non fig. 161 B1 (leaf; Cordaites?).

1944 Sigillaria mamillaris, Bell, pp. 91-92, pl. LIII, fig. 1. v 1944 Sigilaria elegans, Bell, p. 91, pl. XLV, fig. 2; pl. XLVI, fig. 1 (refigured here as Fig. 17e).

1960 Sigillaria, Gillespie and Latimer, p. 22, 38, pl. 2, fig. 2.

v 1966 Sigillaria elegans, Bell, p. 22, pl. X, fig. 1 (refigured here as Figs. $17 \mathrm{c}, \mathrm{d})$.

1966 Sigillaria, Gillespie et al., p. 24, 58, pl. 9, fig. 4 (same as Gillespie and Latimer 1960).

1978 Sigillaria elegans, Gillespie et al., p. 48, 52, 60, pl. 18, fig. 4 (same as Gillespie and Latimer 1960, and Gillespie et al. 1966); pl. 19, fig. 6 (drawing).

2006 Sigillaria mamillaris, Calder et al., p. 180, 181, figs. $9 \mathrm{~A}, \mathrm{~B}$.

Figure 16. (previous page) (a) Flemingites russelianus $(\mathrm{x} 1$ ). Terminal strobilus attached to small branch of Bergeria dilatata. Origin: Minas Basin shore, mouth of Moose River, east side (locality 1411). (b) Enlargement (x 3) of the same specimen. (c) Lepidostrobophyllum hastatum (x 1). Specimens on the reverse side of Bell's holotype of Lepidodendron dichotomum var. bretonensis. Compare Fig. 10a. Origin: Sydney coalfield, Nova Scotia, shore east of Schooner Pond Cove at most westerly crop of McRury seam (locality 513). (d) Flemingites russelianus (x 1). GSC 9953. Impression of strobilus showing its outer surface. Origin: Springhill, South Branch Black river, mouth of Smith Brook (locality 1053). (e) Enlargement (x 3) of specimen in 16d showing the shape of sporophylls. (f) Flemingites russelianus. Origin: Borehole from 2 mine, depth 12-23; Springhill (locality 1496). (g) Bergeria dilatata (x 1). Branchlets with attached leaves. Origin: same as for 16a (locality 1411). (h) Same specimen as 16g, $x$ 3. Repository: Geological Survey of Canada, Ottawa. 

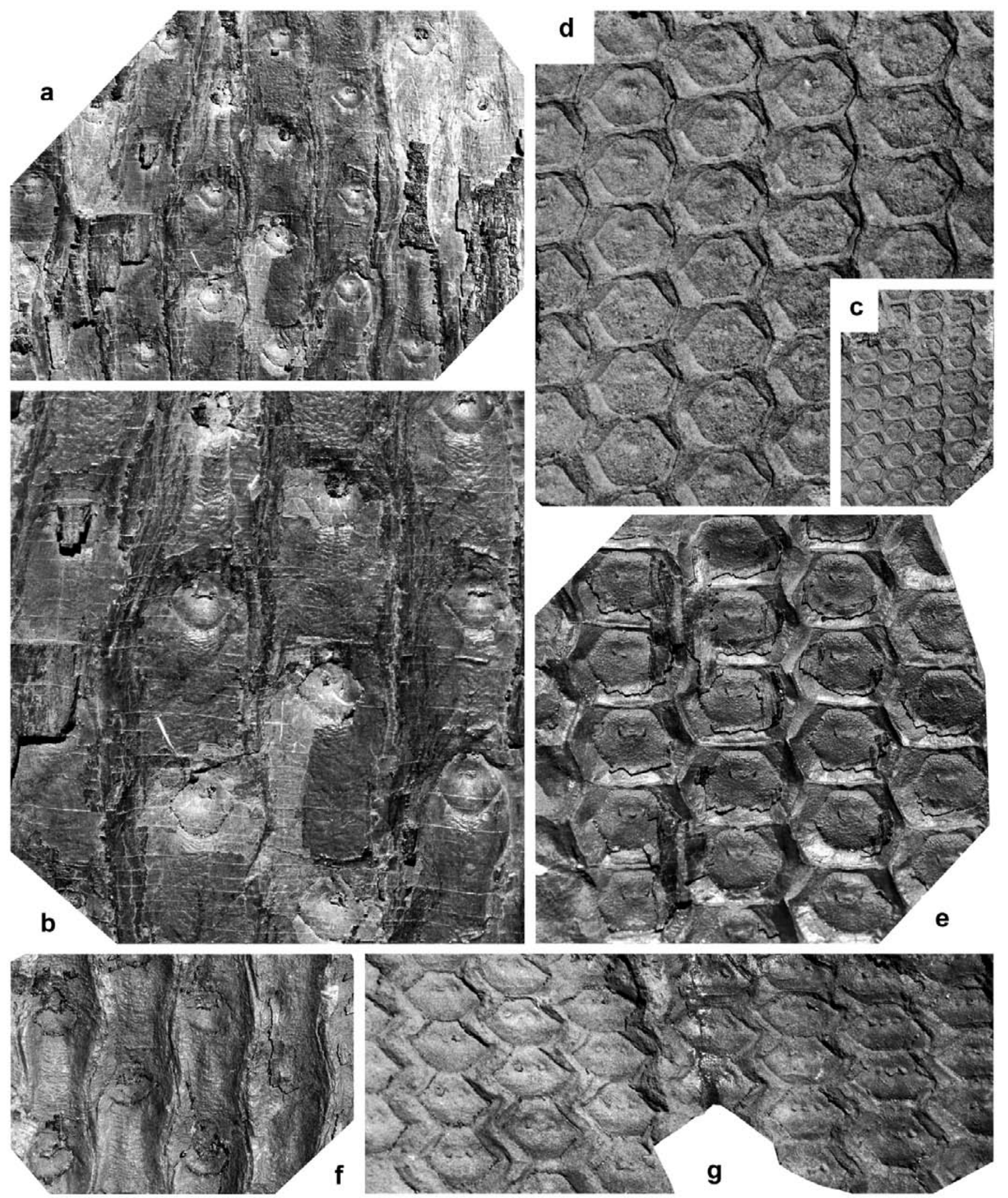
Excludenda:

1957 Sigillaria mamillaris, Janssen, pp. 54-55, fig. 34 (= Sigillaria tessellata).

DESCRIPTION. Ribs 5-8 mm wide, slightly convex, separated by zig-zagging longitudinal furrows. Straight or slightly arched, horizontal (transverse) furrows above the leaf scars which are closely spaced, hexagonal, straightsided, with a slight rounding of the lower margin and a small notch in the upper. Dimensions: about $4 \mathrm{~mm}$ long and $5-6 \mathrm{~mm}$ broad; ratio $=0.6-0.8$. Three small cicatricules arranged in line in the upper third of leaf scar; the central (leaf trace), punctiform to transversely elongate, and the lateral (parichnos) oval and slightly downflexed.

REMARKS. Bell (1944, pp. 91-92, pl. LIII, fig. 1) figured and described one specimen (GSC 5899) from a single locality at Springhill as Sigillaria mamillaris. This specimen is moderately well preserved, and shows characteristic hexagonal leaf scars as well as zigzagging furrows. Crookall (1966, p. 376) included Bell's specimen in the synonymy of Sigillaria mamillaris.

Bell (1944, pl. XLV, fig. 2; pl. XLVI, fig. 1) also figured two specimens from locality 1338 in the Cumberland Basin under the name of Sigillaria elegans. Although Crookall (1966) includes these specimens in the synonymy of Sigillaria elegans, the larger leaf scars exclude Bell's specimens from that species as it is commonly understood. They are here assigned to Sigillaria hexagona, a species generally included in the synonymy of Sigillaria elegans. This poses a taxonomic problem. Brongniart (1837, pl. 146, figs. 1, 1A; pl. 158, fig. 1) illustrated two very similar specimens as Sigillaria elegans and Sigillaria hexagona, respectively. Sigillaria hexagona is a species based on Schlotheim's (1820) Palmacites hexagonatus. We regard both specimens illustrated by Brongniart as Sigillaria elegans sensu Brongniart (non Sternberg), this being the form with small hexagonal leaf scars that occurs from Chokierian to middle Langsettian. Brongniart (1837, pl. 155) further illustrated a specimen with larger leaf scars as Sigillaria hexagona, a determination we accept. However, in the text volume, Brongniart (1837, p. 439) included the specimens that he figured as Sigillaria hexagona with Sigillaria elegans. Three different localities in western Germany were mentioned by Brongniart (1837), without specifying the origin of each specimen. All these occur in lower Westphalian strata.

Sigillaria elegans was introduced by Sternberg (1825, Taf. LII, fig. 4) on the basis of upper Stephanian material from Wettin, Saxony. Jongmans (1932) discussed the taxonomic problem surrounding this species, and suggested that the middle to upper Namurian and lower Westphalian material that had been assigned to Sigillaria elegans by Brongniart might not be conspecific with the (Stephanian) holotype of that species. Jongmans (1932) also suggested that Sternberg's Sigillaria elegans might be conspecific with Sigillaria brardii. However, the name Sigillaria elegans has been generally accepted for the small favularian Sigillaria with often poorly marked, relatively prominent leaf scars of hexagonal shape, which occurs in Namurian and lowermost Westphalian strata. It seems likely that this species (Sigillaria elegans sensu Brongniart, non Sternberg) may be conspecific with Sigillaria minima as figured and described by Brongniart (1837, pp. 435-436, pl. 158, figs. 2, 2A) from Namurian strata in the Vendée, southwestern France. This specimen (holotype) was refigured (photographically) by Bureau (1913, pl. XLI, figs. 3, 3A).

Although Bell $(1940,1944,1966)$ recorded Sigillaria elegans from Canada, we regard his specimens as belonging to Sigillaria hexagona.

STRATIGRAPHIC AND GEOGRAPHIC DISTRIBUTION. Present (under different names) in upper Namurian and Westphalian strata.

OCCURRENCE IN THE MARITIME PROVINCES, CANADA. CUMBERLAND BASIN (NOVA SCOTIA): locality 1374 (cf. - poorly preserved specimen without catalogue number). Bell (1944): locality 667 (one piece without catalogue number); locality $1338=1686$ (GSC $6537+$ GSC 6542 + GSC 8557 - together with Sigillaria scutellata); locality 1498 (part and counterpart - with Senftenbergia plumosa); Springhill (GSC 5899). Bell (1966): locality 1493 (GSC 14934). Calder et al. (2006).

OCCURRENCE IN THE UNITED STATES. WEST VIRGINIA: Gillespie and Latimer (1960); Gillespie et al. (1966).

Figure 17. (previous page) (a) Sigillaria scutellata (x 1). GSC 14936. Part of the specimen figured in Bell (1966, pl. IX, fig. 1). Origin: Springhill, from unspecified coal mine (locality 205). (b) Enlargement (x 3) of specimen in 17a. (c) Sigillaria hexagona (Schlotheim) Brongniart (x 1). GSC 14934. Specimen figured as Sigillaria elegans in Bell (1966, pl. X, fig. 1). Origin: Springhill, north of Deep Brook Mills (locality 1493). (d) Enlargement (x 3 ) of the same specimen. (e) Sigillaria hexagona (x 3). GSC 6542. Specimen figured as Sigillaria elegans in Bell (1944, pl. XLVI, fig. 1). Origin: Joggins, waste dump from mine on main coal seam (locality $1338=1686)$. (f) Sigillaria scutellata $(\mathrm{x} 1)$. Origin: Springhill, from unspecified coal mine (locality 205). (g) Sigillaria hexagona (x 3). Origin: Springhill, old prospect pits on coal seams (locality 667). Repository: Geological Survey of Canada, Ottawa. 

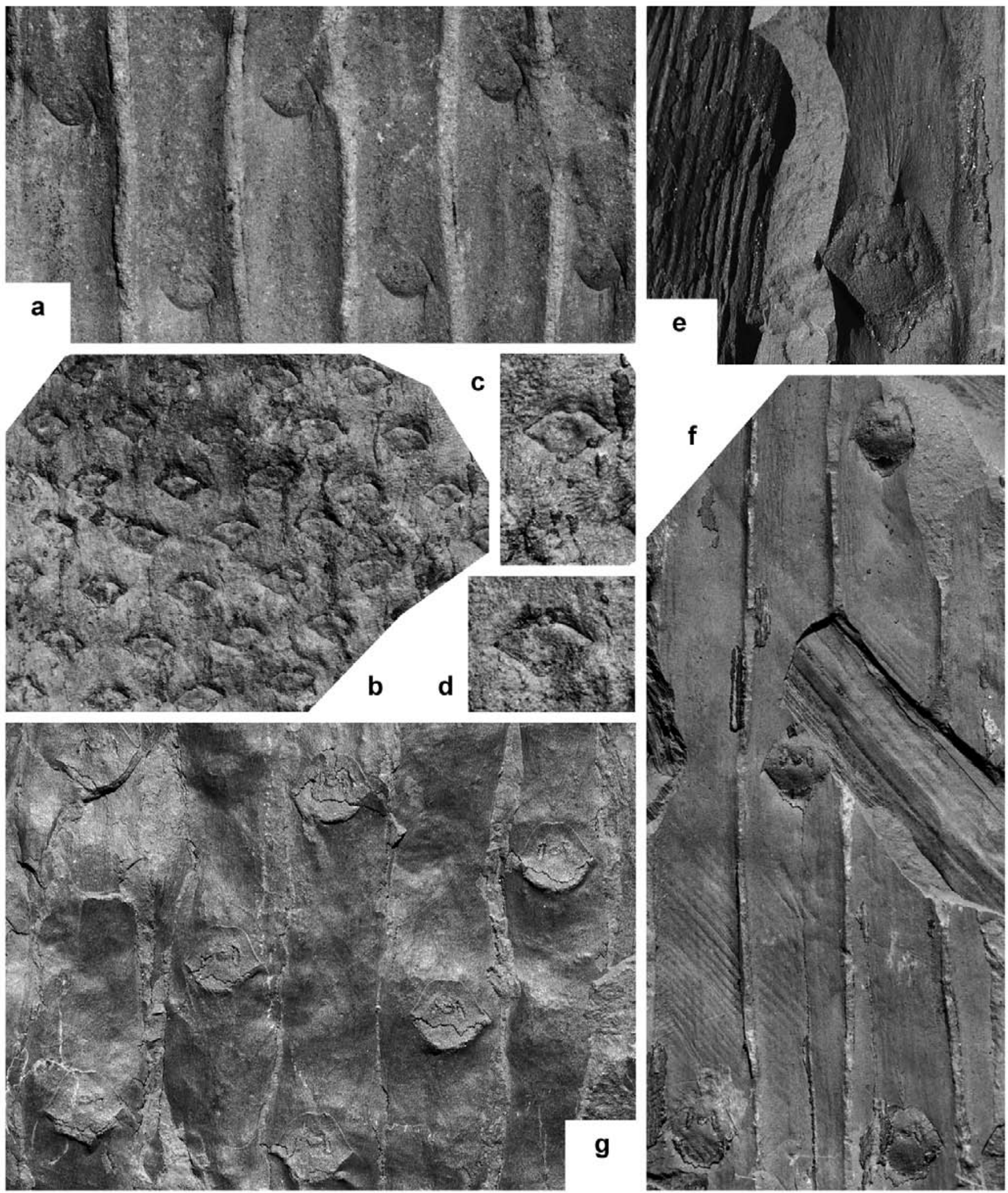
Sigillaria reticulata Lesquereux 1860

(Figs. 18b-d)

* 1860 Sigillaria reticulata Lesquereux, p. 310, pl. III, fig. 2. 1879-80 Sigillaria reticulata, Lesquereux, p. 473, pl. LXXIII, figs. 19, 19a.

1924-26 Sigillaria reticulata, Deltenre, pp. 82-83, pl. XVIII, figs. 7, 8.

* 1924-26 Sigillaria vermiculata Deltenre, p. 84, pl. XVIII, figs. 9, 10.

1940 Sigillaria reticulata, Bell, p. 125, pl. VIII, figs. 1, 2.

v 1944 Sigillaria reticulata?, Bell, p. 93, pl. LVII, fig. 1 (poorly preserved).

T 1966 Sigillaria reticulata, Crookall, pp. 469-471, pl. XCIV, figs. 5-7; text-figs. 138 (copy of Lesquereux 1860, pl. III, fig. 2), 139 (diagrammatic drawing).

v 1995 Sigillaria reticulata, Álvarez-Vázquez, pp. 248-250, lám. 81, fig. 7.

v 2010 Sigillaria reticulata, Wagner and Álvarez-Vázquez, p. 266.

REMARKS. Bell (1940, pl. VIII, figs. 1, 2) illustrated as Sigillaria reticulata two specimens from a borehole in the Pictou coalfield (Stellarton Basin), Nova Scotia, that are typical for this species. The stem is not ribbed and displays well-marked longitudinal wrinkles, as well as relatively small, spaced-out, oval leaf scars. Two specimens from locality 2488, from the same coalfield (see our Fig. 18b-d) show the small, about $1.5-2 \mathrm{~mm}$ long and $3 \mathrm{~mm}$ broad, transversely oval leaf scars, $5 \mathrm{~mm}$ apart in vertical rows on a non-ribbed stem. Although not very well preserved due to the coarseness of the sediment, the short, more or less flexuous wrinkles are visible.

In contrast, the specimen figured by Bell (1944, pl. LVII, fig. 1) as Sigillaria reticulata? from Springhill (locality 1081), Nova Scotia, shows widely spaced oval leaf scars, about 3 $\mathrm{mm}$ long and $4.5 \mathrm{~mm}$ broad, which are separated by an irregularly striped area that we interpret as subepidermal and thus a preservational character. However, it also shows some leaf scars. This specimen resembles that mistakenly figured as Sigillaria brardii var. denudata by Arber (1912, pl. 12, fig. 10) from strata of Asturian age in the Forest of Dean, England. From the same locality (1081), Bell (1944, pl. LVI, fig. 4) figured as Sigillaria laevigata? a decorticated fragment displaying large, paired parichnos in vertical rows on a longitudinally striate stem, clearly in subepidermal preservation. This latter specimen is assigned here to Syringodendron sp.

Sigillaria vermiculata (Deltenre, 1924-1926, p. 84, pl. XVIII, figs. 9, 10) also encompasses non-ribbed material in which the stem is covered by longitudinal, more or less flexuous wrinkles, with oval leaf scars placed in alternating vertical rows. There is no apparent reason to separate this material from Sigillaria reticulata, which Deltenre figured from the same horizon as his type of Sigillaria vermiculata - Veine du Parc, Charleroi coalfield, Belgium.

COMPARISONS. Well-preserved specimens of Sigillaria reticulata with transversely oval leaf scars on a nonribbed stem are sufficiently distinctive to avoid confusion with any other Sigillaria.

There is a faint resemblance with Asolanus camptotaenia, but the latter has smaller, subrhomboidal leaf scars, broader than long, with a characteristic cross-over ornament in between.

STRATIGRAPHIC AND GEOGRAPHIC DISTRIBUTION. Sigillaria reticulata is rare. Its holotype is from White River, Arkansas, U.S.A. In Europe, it has been recorded from the Langsettian of Yorkshire, England (Crookall 1966), the Duckmantian of Belgium (Deltenre 1924-1926), and the upper Duckmantian/lower Bolsovian of Peñarroya in southwestern Spain (Wagner and ÁlvarezVázquez 2010).

OCCURRENCE IN MARITIME PROVINCES, CANADA. CUMBERLAND BASIN (NOVA SCOTIA): Bell (1944): locality $205=1081$ (GSC 10943 - together with Calamites suckowii). PICTOU COALFIELD (STELLARTON BASIN, NOVA SCOTIA): locality 2488 (two pieces without catalogue number). Bell (1940): locality 2684 (GSC 10741 + GSC 10803).

OCCURRENCE IN THE UNITED STATES. ALABAMA: Lesquereux (1879-1880). ARKANSAS: Lesquereux (1860), Lesquereux (1879-1880), Crookall (1966).

Figure 18. (previous page) (a) Sigillaria scutellata (x 2). Part of a specimen collected in August, 1999. Origin: Logan's division 4, Joggins Formation (RHW locality 9897). Repository: Centro Paleobotánico, Real Jardín Botánico de Córdoba. (b) Sigillaria reticulata (x 3). Origin: Ross Bridge, Sutherland River, Pictou coalfield (locality 2488). (c) Enlargement (x 6) of the same specimen to show the leaf scar shape and the ornamentation of the field. (d) Another detail (x 6) of a leaf scar. (e) Sigillaria subrotunda. Detail (x 6) of ornament above leaf scars. Origin: Joggins section, roof shales of coal group $\mathrm{n}^{\circ}$ 29, Logan's division 4 (locality 1339). (f) Sigillaria subrotunda (x 3). GSC 8566. Origin: Joggins section, coal group $\mathbf{n}^{\circ}$ 43, Logan's division 4 (locality 1982). (g) Sigillaria scutellata. Enlargement (x 3) of Bell's holotype of Sigillaria fundiensis (Bell, 1944, pl. LV, fig. 1). Origin: Joggins, waste dump from mine on main coal seam (locality $1338=1686$ ). Repository: Geological Survey of Canada, Ottawa. 
Sigillaria scutellata Brongniart 1822

(Figs. 17a-b, f; 18a, g)

* 1822 Sigillaria scutellata Brongniart, p. 222, pl. I, fig. 4.

1837 Sigillaria scutellata Brongniart, pp. 455-456, pl. 150, fig. 2; pl. 163, fig. 3.

* 1837 Sigillaria notata Brongniart, p. 449, pl. 153, fig. 1 (acc. to Zeiller 1888).

* 1868 Sigillaria Decheni Roehl, p. 116, Taf. XXII, fig. 14 (acc. to Zeiller 1888).

* 1876 Sigillaria duacensis Boulay, p. 43, pl. II, fig. 3 (acc. to Zeiller 1888).

* 1876 Sigillaria nudicaulis Boulay, p. 42, pl. III, figs. 4, 4 bis.

1934 Sigillaria scutellata, Arnold, p. 191, pl. IV, fig. 1.

* v 1944 Sigillaria fundiensis Bell, pp. 92-93, pl. LIV, fig. 1; pl. LV, fig. 1.

v 1944 Sigillaria scutellata, Bell, p. 92, pl. LIII, fig. 2.

1947 Sigillaria scutellata, Arnold, p. 113, fig. 49A (upside down).

p 1949 Sigillaria scutellata, Arnold, p. 177, pl. X, fig. 5; non pl. X, fig. 1 (may resemble Sigillaria laevigata).

1949 Sigillaria sp. (cf. S. mamillaris), Arnold, p. 177, pl. X, fig. 2.

* 1952 Sigillaria Demaneti Stockmans and Willière, pl. C, figs. 2-3a.

? 1957 Sigillaria scutellata, Janssen, p. 57, fig. 38 (separated by Janssen from specimen figured as Sigillaria rugosa by closer spacing of leaf scars and absence of rugosity, though these might be preservational characters; also possible resemblance to Sigillaria orbicularis and Sigillaria ovata).

p 1963 Sigillaria brardii, Wood, p. 38, pl. 2, fig. 9; non pl. 2, fig. 10 (= Syringodendron sp.).

v 1966 Sigillaria scutellata, Bell, pl. IX, fig. 1 (partially refigured here in Figs. 17a, b).

T 1966 Sigillaria scutellata, Crookall, pp. 406-412 (including synonymy), pl. LXXXVIII, figs. 1-3; text-figs. 121 (copy of Brongniart's type), 139 (drawing).

1966 Sigillaria nudicaulis, Crookall, pp. 437-439, pl. XCI, figs. 4-5a; text-fig. 129 (copy of Boulay's types), text-fig. 139 (drawing).

1978 Sigillaria sp., Gillespie et al., p. 52, pl. 17, fig. 2.

1980 Sigillaria scutellata, Zodrow and McCandlish, p. 87, 251, pl. 133, figs. 1-3.

2004 Sigillaria scutellata, Falcon-Lang et al., p. 214, fig. $5 \mathrm{C}$.

2005 Sigillaria sp., Bashforth, p. 39, pl. 2, fig. 10.

2006 Sigillaria scutellata, Calder et al., p. 180, 181, figs. 9D, E (cf. in the explanation).

Excludenda:

1963 Sigillaria scutellata, Wood, p. 39, pl. 3, fig. 3 (to be compared with Sigillaria rugosa).
DESCRIPTION. Ribs 8-15 mm broad, slightly convex, separated by slightly undulate furrows. Leaf scars widely separated (13-20 mm apart), occupying half to two thirds of rib width; subhexagonal, with a notch in the upper margin, and well rounded lower margin. Dimensions: 5-12 mm long and 5-9 mm broad; ratio $=1-1.2$. Vascular trace and parichnos markings in line and situated slightly above the middle of the leaf scar; leaf trace punctiform to oval, and parichnos scars oval, vertically elongate or slightly arched. Ligule pit about $1 \mathrm{~mm}$ above the leaf scar. Intervening rib surfaces between leaf scars smooth or ornamented with short, transverse lines occupying the entire width of rib.

REMARKS. The single specimen from Springhill, Nova Scotia, figured by Bell (1944, pl. LIII, fig. 2) as Sigillaria scutellata, shows the slightly convex ribs as well as the characteristic ornamentation consisting of several transverse or oblique markings that occupy the entire width of ribs below the subhexagonal leaf scars. As usual for this species, the ornamentation is only faintly preserved. Bell (1966, pl. IX, fig. 1) also figured another, more poorly preserved specimen from locality 205 at Springhill. The latter is reillustrated partially as Figs. 17a, b.

Bell (1944, pp. 92-93, pl. LIV, fig. 1; pl. LV, fig. 1) figured and described two specimens from locality 1338 (GSC 8557 and GSC 8555) as a new species, Sigillaria fundiensis. He noted the resemblance with Sigillaria scutellata, but recorded the absence of transverse ornamentation as distinguishing the former species from the latter. However, sigillarian stem remains were often deposited after floating in water for some time, thus often producing a partial decay of superficial tissues. Indeed, such imperfect preservation is rather common. Accordingly, Sigillaria fundiensis is regarded here as based on imperfectly preserved remains of Sigillaria scutellata.

Bell (1944) also compared Sigillaria fundiensis with Sigillaria nudicaulis, a species that may be synonymous with Sigillaria scutellata. In fact, the holotype of Sigillaria fundiensis is strikingly similar to specimens figured as Sigillaria nudicaulis by Crookall (1966, pl. XCI, figs. 4-5a) from Shropshire, England.

COMPARISONS. Sigillaria polyploca Boulay has more convex ribs separated by strongly undulate furrows. Its leaf scars are subpentagonal and each has a clearly rounded lower margin.

Sigillaria mamillaris has flexuous or zigzagging furrows between ribs, which are only $4-10 \mathrm{~mm}$ wide. Its leaf scars are in vertical rows and 2-6 $\mathrm{mm}$ apart; they are hexagonal, with straight lateral margins and a more or less arched lower margin.

STRATIGRAPHIC AND GEOGRAPHIC DISTRIBUTION. According to Josten (1991), in western Germany Sigillaria scutellata ranges from Langsettian to mid- 
Bolsovian, and only rarely beyond. From Great Britain, Crookall (1966) recorded the species (as Sigillaria scutellata and Sigillaria nudicaulis) as being fairly common in Westphalian A (Langsettian) and B (Duckmantian), but rare in Westphalian C (Bolsovian) and D (Asturian).

OCCURRENCE IN THE MARITIME PROVINCES, CANADA. CUMBERLAND BASIN (NOVA SCOTIA): Bell (1944): locality $205=1081$ (GSC 14936 + two pieces without catalogue number); GSC 9897; locality 1081 (GSC 8568); locality 1338 = 1686 (GSC 8555 - holotype of Sigillaria fundiensis + GSC 8557 - together with Sigillaria hexagona). Bell (1966): locality 205 (GSC 14936 - same as Bell, 1944). Falcon-Lang et al. (2004). SYDNEY BASIN (NOVA SCOTIA): Zodrow and McCandlish (1980).

OCCURRENCE IN THE UNITED STATES. ILLINOIS: Janssen (1957). Indiana: Wood (1963). MICHIGAN: Arnold (1934, 1947, 1949). WEST VIRGINIA: Gillespie et al. (1978).

\section{Sigillaria subrotunda Brongniart 1837}

(Figs. 18e-f)

1828a Sigillaria subrotunda Brongniart, p. 65, 172 (nomen nudum).

* 1837 Sigillaria subrotunda Brongniart, p. 458, pl. 147, figs. 5,6 .

* 1837 Sigillaria deutschiana Brongniart, pp. 475-476, pl. 164, fig. 5.

1924-26 Sigillaria Deutschi, Deltenre, pp. 36-38, pl. V, figs. $4,5$.

1966 Sigillaria cf. deutschiana, Crookall, pp. 452-454, pl. XCIV, figs. 3, 4; text-fig. 133 (partial copy of Brongniart 1837, pl. 164, fig. 5).

DESCRIPTION. Slightly convex ribs, smooth or showing a longitudinal striation in decorticated condition, 6-7 mm wide, separated by straight, deep furrows. Leaf scars about $40 \mathrm{~mm}$ apart in vertical rows, occupying two thirds of rib width, subhexagonal, with a notch in the upper margin, a rounded lower margin, and lateral margins prolonged downwards by two short, slightly raised lines. Dimensions: $4-5 \mathrm{~mm}$ long and $4-4.5 \mathrm{~mm}$ broad; ratio = 0.8-1. Cicatricules placed in the upper half of the leaf scar, the central (vascular trace) punctiform, and the two lateral ones (parichnos) oval. A plume is visible above the leaf scars.

REMARKS. Sigillaria subrotunda is more commonly recorded as Sigillaria deutschii (= Sigillaria deutschiana), a synonym. Two specimens from localities 1339 and 1982 (both in the Joggins section) are included in this rare species. These specimens (at GSC Ottawa) were unrecorded by Bell.
COMPARISONS. Sigillaria scutellata shows longer and broader leaf scars that are less widely separated vertically. Also, the surface between leaf scars in Sigillaria scutellata is smooth or ornamented with short, transverse lines.

Sigillaria ovata possesses leaf scars of similar size and that are also well separated vertically, but of ovate shape with rounded margins; furthermore, the rib surfaces are smooth and unornamented.

Sigillaria rugosa possesses more elongate, oval to pyriform leaf scars, which are separated by rugose areas in between the scars.

STRATIGRAPHIC AND GEOGRAPHIC DISTRIBUTION. Sigillaria subrotunda is rare. The type material of both Sigillaria subrotunda and Sigillaria deutschii is from Saarland, western Germany. Crookall (1966) recorded the species (as Sigillaria cf. deutschiana) from the Westphalian B (Duckmantian) of Great Britain. The specimens figured and described by Deltenre (1924-1926) originated from the Duckmantian of Belgium.

OCCURRENCE IN THE MARITIME PROVINCES, CANADA. CUMberland basin (nOva SCOTIA): Previously undescribed material: locality 1339 (without catalogue number - together with Eusphenopteris sauveurii + Dorycordaites palmaeformis and Cyperites sp.); locality 1982 (GSC 8566 - with Dorycordaites palmaeformis and Cyperites sp.).

Genus Sigillariostrobus Schimper 1870

TYPE. Sigillariostrobus goldenbergii Feistmantel 1876

REMARKS. This rarely cited genus includes large, cylindrical strobili borne on long and thin stalks covered by bracts near the base. The sporophylls are disposed in pseudoverticils on a broad central axis; they are more or less obliquely inserted and triangular to lanceolate, with entire or ciliate margins.

\section{Sigillariostrobus sp. 1}

p 1944 Gymnostrobus salisburyi, Bell, pp. 95-96, pl. LXI, fig. 2; non pl. LXII, fig. 4 (=Stigmaria ficoides).

REMARKS. Bell (1944) figured two specimens as Gymnostrobus salisburyi. One of these (Bell 1944, pl. LXI, fig. 2) is an incomplete but apparently cylindrical strobilus, up to $190 \mathrm{~mm}$ long and $30 \mathrm{~mm}$ wide, with sporangia that are perpendicularly inserted, about $10 \mathrm{~mm}$ long; sporophylls 
are not clearly visible. We regard it as a sigillarian strobilus, but cannot assign it more precisely. The other specimen figured as Gymnostrobus salisburyi (Bell 1944, pl. LXII, fig. 4), is clearly a rhizomorph attributable to Stigmaria ficoides (see later).

OCCURRENCE IN THE MARITIME PROVINCES, CANADA. CUMBERLAND BASIN (NOVA SCOTIA): Bell (1944): locality $1388=2990($ GSC 10112).

Lycopsid strobilus

(Fig. 19)

DESCRIPTION. Apparently cylindrical strobilus, about $40 \mathrm{~mm}$ broad and over $120 \mathrm{~mm}$ in length; neither the base nor the apex are preserved. Sporophyll laminae up to $20 \mathrm{~mm}$ long, closely adpressed and largely overlapping; shape of distal lamina is indistinct, but possibly elongate subtriangular.

REMARKS. The figured specimen is an incomplete, large, lycopsid strobilus from the Joggins section (locality 1343 - GSC Ottawa), unrecorded by Bell. It cannot be assigned reliably to either Sigillariostrobus or Lepidostrobus, since its incomplete preservation prevents ascertaining the presence or absence of a peduncle. The coarseness of the sediment is another impediment for a generic assignment.

OCCURRENCE IN THE MARITIME PROVINCES, CANADA. CUMBERLAND BASIN (NOVA SCOTIA): locality 1343 (one piece without catalogue number).

Genus Cyperites Lindley and Hutton 1832

TYPE. Cyperites bicarinatus Lindley and Hutton 1832

$$
\text { Cyperites sp. }
$$

1944 Lepidophyllum sp., Bell, pp. 96-97, pl. LIX, fig. 2.

REMARKS. Bell (1944) figured as Lepidophyllum sp. some fragmentary lycopsid leaves, $40-50 \mathrm{~mm}$ wide and up to $100 \mathrm{~mm}$ long. The long, narrow, single-veined leaves (as described by Bell, but not clear from his illustrations) are commonly referred to as Cyperites (or its synonym Sigillariophyllum). The name Cyperites is applied to long leaves that occur in several genera of arborescent Carboniferous lycopsids (e.g., Sigillaria, Lepidodendron sensu stricto, Lepidophloios, Omphalophloios, Polysporia).

Snigirevskaya (1958) replaced Lepidophyllum, the name most commonly applied to leaves only a few centimetres long (in contrast to the much longer, narrow, and parallelsided leaves of Cyperites) by Lepidophylloides. She explained that the name Lepidophyllum was preoccupied by a living angiosperm genus.

STRATIGRAPHIC AND GEOGRAPHIC DISTRIBUTION. Cyperites is common throughout the Carboniferous.

OCCURRENCE IN THE MARITIME PROVINCES, CANADA. CUMBERLAND BASIN (NOVA SCOTIA): Bell (1944): locality 1685 (GSC 8207).

\section{Genus Stigmaria Brongniart 1822}

TYPE. Stigmaria ficoides (Sternberg 1820) Brongniart 1822

REMARKS. This genus includes the repeatedly dichotomized, laterally extensive rhizomorphs of a number of arborescent lycopsids. Stigmaria characteristically shows

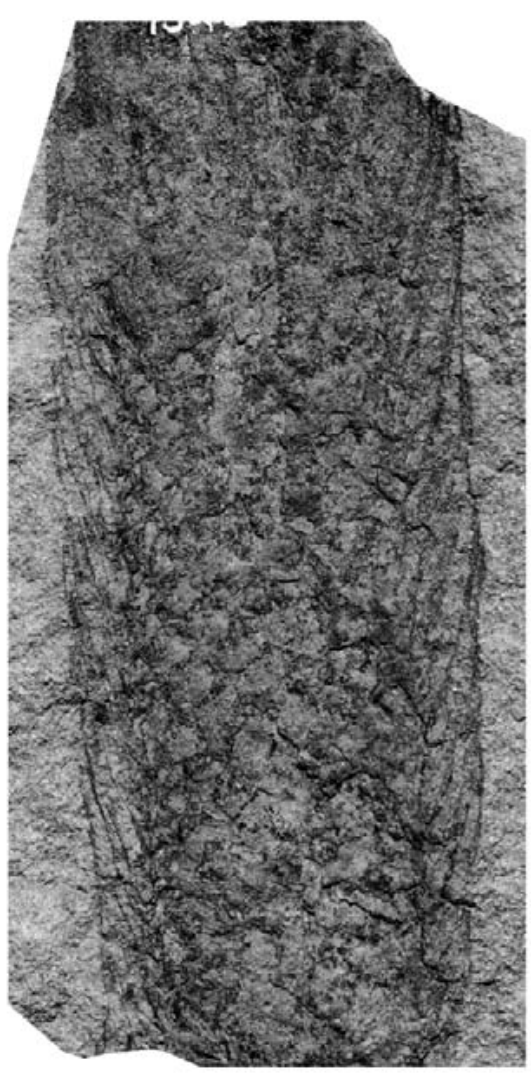

Figure 19. Lycopsid strobilus (x 1). Origin: Joggins, Logan's division 4, beds of coal group $n^{\circ} 29$ (locality 1343). 
the main roots coming off at four corners of the swollen tree base. Small fragments are easily recognized by the irregular, circular rootlet scars on smooth or wrinkled surfaces, in some species with a stellate ornament surrounding the scar. Stigmaria remains are common throughout the Carboniferous, generally as molds/casts. Anatomically preserved specimens of Stigmaria are common in coal balls.

Omphalophloios root terminals, as figured by Wagner (1999, lám. 6, fig. 2; Wagner et al. 2003, fig. 16) show a blunt termination with an overtopped dichotomy, and small, subcircular rootlet scars, as well as relatively coarse appendices (rootlets). The number of points at which dichotomous rhizomorphs leave the stem base of this tree is unknown. The rootlet scars in Omphalophloios are notably smaller and more circular in outline than those of Stigmaria. The rhizomorph terminals mimic the rounded stem apices with unequal dichotomy, a condition that occurs occasionally in Omphalophloios.

\section{Stigmaria ficoides (Sternberg 1820) Brongniart 1822}

* 1820 Variolaria ficoides Sternberg, Taf. XII, figs. 1-3.

$\$ 1822$ Stigmaria ficoïdes, Brongniart, p. 228, 239, pl. I, fig. 7.

1868 Stigmaria ficoides, Dawson, p. 475, fig. 30d.

* 1870 Stigmaria elliptica Lesquereux, p. 451, pl. XXIX, fig. 2 (acc. to Janssen 1940).

* 1871 Stigmaria perlata Dawson, p. 22, pl. III, fig. 32 (acc. to Stopes 1914).

* 1871 Stigmaria areolata Dawson, p. 23, pl. III, fig. 33.

1873 Stigmaria, Dawson, p. 20, 46, pl. IV, figs. 30-31.

p 1879-80 Stigmaria ficoides, Lesquereux, pp. 514-515, pl. LXXIV, figs. 1, 2; fig. 3 (as var. undulata), fig. 6 (as var. minus); non fig. 4 (var. stellata $=$ Stigmaria stellata).

* 1879-80 Lepidostrobus (Macrocystis) Salisburyi Lesquereux, pp. 443-444, pl. LXIX, figs. 1, 2 (as Lepidostrobus macrocystis in the text plate) (acc. to Chaloner and Boureau in Boureau 1967).

1925 Stigmaria ficoides, Noé, p. 14, pl. XII, figs. 1-3.

1934 Stigmaria ficoides, Arnold, p. 192, pl. V. figs. 2, 5.

1938 Stigmaria ficoides, Bell, p. 103, pl. CV, fig. 8.

1940 Stigmaria ficoides, Janssen, pp. 27-28, pl. VIII, fig. 3 (photograph of holotype of Stigmaria elliptica).

p 1944 Gymnostrobus salisburyi, Bell, pl. LXII, fig. 4; non pp. 95-96, pl. LXI, fig. 2 (= Sigillariostrobus sp. 1).

1947 Stigmaria ficoides, Arnold, p. 119, figs. 16, 53A, B (drawing); fig. 54 (anatomy).

1949 Stigmaria ficoides, Arnold, pp. 178-179, pl. XI, fig. 1 (same as Arnold, 1947: fig. 16); fig. 2 (Arnold, 1947: fig. 53).

1957 Stigmaria ficoides, Janssen, p. 68, fig. 52.

1959 Stigmaria sp., Canright, pl. 1, fig. 12.

1959 Stigmaria ficoides var. undulata, Canright, pl. 1, fig. 14.
1960 Stigmaria, Gillespie and Latimer, pl. 2, figs. 1, 1a.

1962 Stigmaria ficoides, Gillespie and Clendening, pl. 6, fig. 3.

1966 Stigmaria ficoides, Bell, pl. IX, fig. 2.

T 1966 Stigmaria ficoides, Crookall, pp. 549-556 (including synonymy), pl. CIV, figs. 1-3; pl. CV, figs. 1, 2; pl. CVI, fig. 5 (similar to specimen figured by Bell 1944, pl. LXI, fig. 2); text-figs. 155A, B (copy of Sternberg 1820, Taf. XII, figs. 2, 3).

1966 Stigmaria, Gillespie et al., p. 24, 54, pl. 7, figs. 1, 1 a. 1968 Stigmaria ficoides, Abbott, pp. 13-14, pl. 19, fig. 3.

1967 Stigmaria ficoides, Tidwell, p. 23, pl. 1, fig. 1.

1970 Stigmaria ficoides, Jennings, p. 170, figs.. 6, 10.

1975 Stigmaria ficoides, Boneham, p. 99, pl. 1, fig. 8.

1978 Stigmaria ficoides, Gillespie et al., p. 50, 52, pl. 19, fig. 1; pl. 21, figs. 3, 4 (same as Gillespie et al. 1966), fig. 5.

1980 Stigmaria ficoides, Jennings, p. 153, pl. 1, fig. 9.

P 1980 Stigmaria ficoides, Zodrow and McCandlish, pl. 140, figs. 1, 2; non pl. 139, fig. 2 (difficult to judge from illustration)

1982 Stigmaria ficoides, Oleksyshyn, pp. 30-31, figs. 9C, D.

1984 Stigmaria ficoides, Rothwell, p. 1032, figs. 1-5.

1991 Stigmaria ficoides, Rothwell and Pryor, p. 1741, figs. 1-6 (molds/casts as well as permineralized material).

1992 Stigmaria ficoides, Tidwell et al., p. 1018, figs. 3.4, 3.7.

1996 Stigmaria ficoides, Cross et al., p. 404, figs. 23-9.1, $4,5$.

T 1997 Stigmaria ficoides, Kvaček and Kvaček, p. 75, pl. 18, fig. 5 (same as Sternberg, 1820, Taf. XII, fig. 1).

2004 Stigmaria ficoides, Falcon-Lang et al., p. 214, fig. 5B.

2005 Stigmaria ficoides, Bashforth, p. 40, pl. 2, fig. 9.

2006 Stigmaria, Falcon-Lang, p. 40, 41, fig. 8C.

REMARKS. This common species is characterized by a laterally extensive rooting system of repeated equal dichotomies of main roots at four corners of the stem base. Apart from the specimen that clearly has helicoidally arranged circular scars and attached rootlets figured by Bell (1966, pl. IX, fig. 2), it is likely that one of the two remains figured as Gymnostrobus salisburyi by Bell (1944, pl. LXII, fig. 4) also represents Stigmaria ficoides. As noted above, the other specimen (Bell 1944, pl. LXI, fig. 2) is a Sigillariostrobus. Jongmans (1930) compared Gymnostrobus salisburyi with Stigmaria and it was listed as a synonym of Stigmaria ficoides by Chaloner and Boureau in Boureau (1967, p. 675). Specimens with a similar state of preservation were figured as Stigmaria ficoides by Kidston (1902, pl. LII, fig. 3) and Arber (1920, pl. XL, fig. 1; pl. XLI, fig. 4). 
COMPARISONS. Stigmaria stellata is distinguished by the stellate pattern of ridges radiating from each of the rootlet scars.

Stigmaria evenii has smaller circular to oval rootlet scars, about $3 \mathrm{~mm}$ diameter, set among relatively short, less regularly disposed, undulating ridges.

STRATIGRAPHIC AND GEOGRAPHIC DISTRIBUTION. Stigmaria ficoides is widely distributed in both Mississippian and Pennsylvanian strata. Its stratigraphic value is restricted to the recognition that it is a Carboniferous plant fossil.

OCCURRENCE IN THE MARITIME PROVINCES, CANADA. CUMBERLAND BASIN (NOVA SCOTIA): Dawson (1868). Bell (1944): locality $666=1141$ (GSC 10277). Bell (1966): locality 1343 (GSC 14932). Falcon-Lang et al. (2004). SYDNEY BASIN (NOVA SCOTIA): Bell (1938): locality Cranberry Head (GSC 4400). Zodrow and McCandlish (1980). ST.JOHN (NEW BRUNSWICK): Dawson (1871). FalconLang (2006). NEWFOUNDLAND: Bashforth (2005).

OCCURRENCE IN THE UNITED STATES. ARIZONA: Tidwell et al. (1992). COLORADO: Jennings (1980). ILLINOIS: Lesquereux (1870), Noé (1925), Janssen (1940, 1957), Jennings (1970). Indiana: Canright (1959), Boneham (1975). IOWA: Rothwell (1984). KENTUCKY: Rothwell and Pryor (1991). Michigan: Arnold (1934, 1947, 1949). oHio: Abbott (1968), Cross et al. (1996). Pennsylvania: Lesquereux (1879-1880), Oleksyshyn (1982). UTAH: Tidwell (1967). WEST VIRGINIA: Lesquereux (1879-1880), Gillespie and Latimer (1960), Gillespie and Clendening (1962), Gillespie et al. (1966), Gillespie et al. (1978).

Order Isoetales

Genus Omphalophloios White 1898

TYPE. Omphalophloios anglicus (Sternberg 1823) Kidston 1901

REMARKS. The work by Brousmiche-Delcambre et al. (1995) has shown that Omphalophloios as figured and described by White (1899) represents a mixture of vegetative stem imprints and parts of fully disarticulated fertile apices of stems. The latter show pseudocushions and imprints of the proximal parts of sporangia, and resemble leaf cushions. This explains the morphological variation of apparent leaf cushions and scars that baffled previous authors. Brousmiche-Delcambre et al. (1995) also established the synonymy with the fructification genus Sporangiostrobus.

Omphalophloios anglicus (Sternberg 1823) Kidston 1901

(Figs. 4c-d)
* 1823 Lepidodendron anglicum Sternberg, Taf. XXIX, fig. 3.

* 1879-80 Lepidodendron cyclostigma Lesquereux, pp. 394-395, pl. LXII, fig. 5 (acc. to Kidston 1901).

1898 Omphalophloios cyclostigma (Lesquereux) White, pp. 336-337, pl. 20; pl. 21, figs. 1-5; pl. 22, figs. 1, 2, fig. 3 (holotype); pl. 23.

1899 Omphalophloios cyclostigma, White, pp. 218-230, pl. LXV; pl. LXVI, figs. 1-5; pl. LXVII, figs. 1-2a; pl. LXVIII, figs. 1, 2.

$\$ 1901$ Omphalophloios anglicus, Kidston, p. 139 (wrongly interpreted as a rhizomorph).

1912 Omphalophloios anglicus, Cambier and Renier, pp. 68-80, pls IX-XI.

v p 1944 Lepidodendron jaraczewskii, Bell, pl. LI, fig. 1; non p. 89, pl. LI, fig. 2 (= "Lepidodendron" feistmantelii).

T 1966 Omphalophloios anglicus, Crookall, pp. 481-482 (including synonymy), pl. XCIX, figs. 1, 2; text-fig. 141 (copy of Sternberg's illustration).

T 1997 Omphalophloios anglicus, Kvaček and Kvaček, p. 33, pl. 5, fig. 5 (photograph of Sternberg's holotype).

DESCRIPTION. Leaf cushions contiguous, spirally arranged, rhomboidal, longer than broad, with maximum width in the upper third, rounded lateral angles, and acute base and apex. Keel absent. Dimensions: 19-22 mm long and $10 \mathrm{~mm}$ broad; ratio $=1.9-2.2$. Leaf scars rhomboidal, placed in the centre of the cushions or slightly above, with sharp lateral angles and more rounded upper and lower ones, displaying a relatively big, rounded cicatricule (leaf trace) in its upper part. Parichnos absent. Dimensions: 3-4 $\mathrm{mm}$ long and 5-6 $\mathrm{mm}$ broad; ratio $\approx 0.6$.

REMARKS. One of the lycopsid stem fragments figured by Bell (1944, pl. LI, fig. 1 - upside down) as Lepidodendron jaraczewskii, shows protruding leaf scars situated a little above the central part of the rhombic leaf cushion. Bell recorded the apparent absence of a leaf trace and of transpiratory (parichnos) scars. However, since his illustration inadvertently combines a specimen of "Lepidodendron" feistmantelii with one of Omphalophloios anglicus (a species that he did not consider), his comment regarding the absence of a leaf trace seems to refer to the specimen attributable to "Lepidodendron" feistmantelii rather than that referable to Omphalophloios. The latter displays a vascular trace in at least some of the leaf scars. Bell considered that the absence of leaf trace and parichnos was due to the scars being covered over by a coaly substance, but this explanation is unconvincing. Parichnos are clearly absent, not covered over. The total absence of parichnos is a notable character of Omphalophloios (BrousmicheDelcambre et al. 1995).

Kidston (1901) synonymized Omphalophloios cyclostigma with Lepidodendron anglicus and transferred 
the latter to Omphalophloios. However, Kidston regarded Omphalophloios as a rhizomorph akin to Stigmaria, a suggestion that may have been based on the absence of parichnos. Cambier and Renier (1912) figured stem remains with attached leaves and identified (correctly) the published remains of Omphalophoios as subaerial parts of a lycopsid tree.

STRATIGRAPHIC AND GEOGRAPHIC DISTRIBUTION. The holotype of Omphalophloios anglicus is from upper Asturian strata of Somerset, Great Britain, where this species is very rare (according to Crookall 1966). Lesquereux and White's specimens originated from Clinton, Missouri, probably lower Asturian. Belgian material (Cambier and Renier 1912) comes from the Langsettian of the Charleroi Basin.

OCCURRENCE IN THE MARITIME PROVINCES, CANADA. CUMBERLAND BASIN (NOVA SCOTIA): Bell (1944): locality 1337 (GSC 8712).

OCCURRENCE IN THE UNITED STATES. MISSOURI: Lesquereux (1879-1880), White (1898), White (1899).

\section{SUMMARY AND CONCLUSIONS}

The record of lycopsid taxa from the lower to middle Westphalian of the Maritime Provinces is due to sporadic, rather than systematic, collecting by personnel of the Geological Survey of Canada, and the availability of material associated with coal mining. The record is therefore incomplete and subject to facies bias. Lycopsids are known to be major contributors to the swamp flora represented in coal seams and are underrepresented in non-swamp environments. Although lycopsid bark fragments are fairly common in drifted, allochthonous assemblages, partial decay ("decortication") has often removed the characteristic leaf cushions ("bolsters") and leaf scars, rendering such remains indeterminable. They often go unrecorded.

Given these factors, it is no surprise that determinable lycopsid remains are virtually absent from the classic Fern Ledges locality in Saint John, New Brunswick, which is characterized by allochthonous remains, and that only a limited number of localities in the Cumberland and Stellarton basins in Nova Scotia, and in the Minto coalfield of New Brunswick, have yielded material. Despite these limitations, related to habitat as well as taphonomy, it is apparent that the composition of the lycopsid flora from lower/middle Westphalian strata of the Maritimes is strikingly similar to that found in western Europe, particularly in the British Isles.

We have re-examined material recorded previously by Dawson (1868) and Bell (1940, 1944, 1966), with only a few additions from Geological Survey collections in Ottawa that were apparently unavailable to Bell, and have taken the opportunity to revise and update the taxonomy. As part of this process, we have reinstated one of Dawson's species (here recorded as Diaphorodendron decurtatum), ignored by previous authors. Additionally, we have reinterpreted the genus Bergeria as accommodating lepidodendroid species with false leaf scars, as defined by Chaloner and Boureau (1967).

Table 1 compares identifications in the present paper against those provided by Dawson $(1868,1873)$ and Bell (1944). Some of Bell's species are placed in synonymy, thus focusing the resemblance of the Westphalian floras of the Maritime Provinces of Canada with that from western Europe. We note in passing that a revision of taxa recorded from the United States is long overdue. 
Table 1. List of the various species figured and described in the present paper in comparison with the identifications in Bell (1944) and Dawson $(1868,1873)$.

\begin{tabular}{|c|c|c|}
\hline Lepidodendron aculeatum & Lepidodendron aculeatum? & \\
\hline Lepidodendron bellii sp. nov. & Lepidodendron obovatum? & \\
\hline "Lepidodendron" feistmantelii & Lepidodendron jaraczewskii (pars) & Lepidodendron aculeatum (pars) \\
\hline "Lepidodendron" cf. tijoui & Lepidodendron rimosum & \\
\hline Lepidophloios laricinus & Lepidophloios laricinus (pars) & \\
\hline Lepidostrobus ornatus & Lepidostrobus variabilis? & \\
\hline Lepidostrobus cf. brongniartii & Lepidostrobus olryi (pars) & \\
\hline Lepidostrobophyllum lanceolatum & Lepidostrobophyllum lanceolatum & \\
\hline Lepidostrobophyllum majus & Lepidostrobophyllum majus & \\
\hline Lepidostrobophyllum morrisianum & Lepidostrobophyllum fletcheri & \\
\hline Diaphorodendron decurtatum & Lepidodendron dichotomum var. bretonensis & $\begin{array}{l}\text { Lepidodendron decurtatum }+ \\
\text { Lepidodendron Sternbergii (pars) }\end{array}$ \\
\hline Sigillaria hexagona & Sigillaria mamillaris + Sigillaria elegans & \\
\hline Sigillaria reticulata & Sigillaria reticulata? & \\
\hline Sigillaria scutellata & Sigillaria fundiensis + Sigillaria scutellata & \\
\hline \multicolumn{3}{|l|}{ Sigillaria subrotunda } \\
\hline Sigillariostrobus sp. 1 & Gymnostrobus salisbury (pars) & \\
\hline \multicolumn{3}{|l|}{ Lycopsid strobilus } \\
\hline Cyperites sp. & Lepidophyllum sp. & \\
\hline Stigmaria ficoides & Gymnostrobus salisbury (pars) & Stigmaria ficoides \\
\hline Omphalophloios anglicus & Lepidodendron jaraczewskii (pars) & \\
\hline
\end{tabular}




\section{ACKNOWLEDGEMENTS}

We are most grateful to John Utting of the Geological Survey of Canada (Calgary) for initiating the general revision of lower Westphalian floras in the Maritimes, and the logistic support for several visits by the second author. Not only his talent for organization, but his personal involvement during these visits provided a lasting stimulus. Jean Dougherty was most helpful in providing access and data regarding the fossil collections of the Geological Survey of Canada in Ottawa. Randall Miller did likewise in the New Brunswick Museum at Saint John, providing also much needed geological information and facilitating a visit to the Fern Ledges locality. We thank Anthony Howell of the Redpath Museum in Montreal for a photograph of the holotype of Lepidodendron decurtatum. Donald Reid (formerly of Joggins Fossil Centre, now associated with the Joggins Fossil Institute) kindly lent the specimen of Lepidostrobus ornatus figured in this paper. Cyrille Prestianni searched (fruitlessly) for the types of Lepidodendron costcei, Lepidodendron obtusum and Lepidodendron dissitum in Brussels and Liège. The two referees, Bill DiMichele (National Museum of Natural History, Washington, D.C.) and Stanislav Opluštil (Charles University, Prague), provided thorough reviews which allowed rounding off this paper. Their insight has provided several pertinent points. Bill DiMichele kindly allowed his clarifications to be quoted as personal communications. The meticulous editing by Rob Fensome has allowed a final revision aimed at improving the clarity of presentation. His efforts are much appreciated.

\section{REFERENCES}

Abbott, M.L. 1963. Lycopod fructifications from the Upper Freeport (No. 7) coal in southeastern Ohio. Palaeontographica, Abt. B, 112 (4-6), pp. 93-118.

Abbott, M.L. 1968. Lycopsid stems and roots and sphenopsid fructifications and stems from the Upper Freeport coal of southeastern Ohio. Palaeontographica Americana, VI (38), pp. 1-49.

Alison, D. and Carroll, R. 1972. Catalogue of Type and Figured Specimens, Fossil Vertebrates, Invertebrates and Plants in the Redpath Museum, McGill University. Redpath Museum, McGill University, Montreal, pp. $1-173$.

Allen, K.C. 1961. Lepidostrobophyllum fimbriatum (Kidston 1883) from the Drybrook Sandstone (Lower Carboniferous). Geological Magazine, XCVIII (3), pp. 225-229. http://dx.doi.org/10.1017/S0016756800060477

Álvarez-Vázquez, C. 1995. Macroflora del Westfaliense inferior de la cuenca de Peñarroya-Belmez-Espiel (Córdoba). I (texto): 1-393, text-figs. 1-21; II (láminas): láms 1-100; III (anexos): anexo 1: 1-7; anexo 2: 1-111; anexo 3: cuadros 1-9; anexo 4: planos 1-4. Unpublished Ph.D. thesis, Departamento de Geología, Universidad de Oviedo.

Álvarez-Vázquez, C. 2000. Nuevos datos aportados por la macroflora a la datación y conocimiento de la cuenca carbonífera de Peñarroya-Belmez-Espiel (Córdoba, SO España). Trabajos de Geología, 21 (Volumen Homenaje a J. Truyols), pp. 37-46.

Álvarez-Vázquez, C. and Wagner, R.H. 2012. La colección de fósiles vegetales del Carbonífero del Centro Paleobotánico del Real Jardín Botánico de Córdoba. Geotemas, 13, pp. 1232-1235.

Andrews, H.N. 1955. Index of Generic Names of Fossil Plants, 1820-1950, Based on the Compendium Index of Paleobotany of the U.S. Geological Survey. U.S. Geological Survey Bulletin, 1013, pp. 1-262.

Arber, E.A.N. 1903. Notes on Fossil Plants from the Ardwick Series of Manchester. Memoirs and Proceedings of the Manchester Literary and Philosophical Society, XLVIII (2), pp. 1-33.

Arber, E.A.N. 1912. On the Fossil Flora of the Forest of Dean Coalfield (Gloucestershire), and the Relationships of the Coalfields of the West of England and South Wales. Philosophical Transactions of the Royal Society of London, Series B, 202, pp. 233-281. http://dx.doi. org/10.1098/rstb.1912.0008

Arber, E.A.N. 1914. On the Fossil Floras of the Wyre Forest, with Special Reference to the Geology of the Coalfield and its Relationships to the Neighbouring Coal Measure Areas. Philosophical Transactions of the Royal Society of London, Series B, CCIV, pp. 363-445. http://dx.doi. org/10.1098/rstb.1914.0009

Arber, E.A.N. 1920. On the Fossil Flora of the Southern Portion of the Yorkshire Coalfield. Part II. North Derbyshire. Proceedings of the Yorkshire Geological Society, New Series, XIX (V), pp. 350-358.

Arber, E.A.N. 1922. Critical studies of coal-measure plant impressions. Journal of the Linnean Society, Botany, XLVI, pp. 171-217.

Arnold, C.A. 1934. A Preliminary Study of the Fossil Flora of the Michigan Coal Basin. Contributions from the Museum of Paleontology, University of Michigan, IV (11), pp. 177-203.

Arnold, C.A. 1947. An introduction to Paleobotany. McGraw-Hill Book Company, New York, 433 p.

Arnold, C.A. 1949. Fossil Flora of the Michigan Coal Basin. Contributions from the Museum of Paleontology, University of Michigan, VII (9), pp. 131-269.

Bashforth, A.R. 2005. Late Carboniferous (Bolsovian) macroflora from the Barachois Group, Bay St. George Basin, southwestern Newfoundland, Canada. Palaeontographica Canadiana, 24, pp. 1-123.

Basson, P.W. 1968. The Fossil Flora of the Drywood Formation of Southwestern Missouri. University of 
Missouri Studies, XLIV, pp. 1-170.

Bateman, R.M. and DiMichele, W.A. 1991. Hizemodendron, gen. nov., a pseudoherbaceous segregate of Lepidodendron (Pennsylvanian): phylogenetic context for evolutionary changes in lycopsid growth architecture. Systematic Botany, 16 (1), pp. 195-205. http://dx.doi. org/10.2307/2418983

Bateman, R.M., DiMichele, W.A., and Willard, D.A. 1992. Experimental cladistic analysis of anatomically preserved arborescent lycopsids from the Carboniferous of Euramerica: an essay on paleobotanical phylogenetics. Annals of the Missouri Botanical Garden, 79 (3), pp. 500559. http://dx.doi.org/10.2307/2399752

Bell, W.A. 1938. Fossil Flora of Sydney Coalfield, Nova Scotia. Canada Department of Mines and Resources, Mines and Geology Branch, Geological Survey, Memoir 215, 334 p.

Bell, W.A. 1940. The Pictou Coalfield, Nova Scotia. Canada Department of Mines and Resources, Mines and Geology Branch, Geological Survey, Memoir 225, 161 p.

Bell, W.A. 1944. Carboniferous rocks and fossil floras of northern Nova Scotia. Canada Department of Mines and Resources, Mines and Geology Branch, Geological Survey, Memoir 238, 119 p.

Bell, W.A. 1962. Flora of Pennsylvanian Pictou Group of New Brunswick. Geological Survey of Canada, Department of Mines and Technical Surveys, Bulletin 87, 71 p.

Bell, W.A. 1966. Illustrations of Canadian Fossils. Carboniferous Plants of Eastern Canada. Geological Survey of Canada, Department of Mines and Technical Surveys, Paper 66-11, pls I-XXXVI.

Berger, R. 1848. De fructibus et seminibus ex formatione lithanthraeum, Vratislaviae, $32 \mathrm{p}$.

Binney, E.W. 1862. On some fossil plants showing structure from the Lower Coal Measures of Lancashire. Quarterly Journal of the Geological Society, London, XVIII, pp. 106111. http://dx.doi.org/10.1144/GSL.JGS.1862.018.0102.20

Binney, E.W. 1871. Observations on the structure of fossil plants found in the Carboniferous strata. pt. II. Lepidostrobus and some allied cones. Palaeontographical Society Monograph, pp. 33-62.

Boneham, R.F. 1975. Chieftain No. 20 Flora (Middle Pennsylvanian) of Vigo County, Indiana. Proceedings of the Indiana Academy of Science for 1974, 84, pp. 89-113.

Boulay, N. 1876. Le terrain houiller du Nord de la France et ses végétaux fossiles. Thèse de Géologie, Faculté des Sciences de Caen, Imprimérie Lefebvre-Ducrocq, Lille, $74 \mathrm{p}$.

Boureau, E. 1967. Traité de Paléobotanique. T. II: Jovet-Ast, S. - Premier Embranchement. Bryophyta: 19-190, textfigs. 1-108; Höeg, O.A. - Deuxième Embranchement. Psilophyta: 191-433, text-figs. 109-309; Chaloner, W.G. \& Boureau, E. - Troisième Embranchement. Lycophyta:
435-802, text-figs. 310-507. Masson et Cie, Paris.

Brack-Hanes, S.D. and Thomas, B.A. 1983. A reexamination of Lepidostrobus Brongniart. Botanical Journal Linnean Society, 86 (1/2), pp. 125-133. http:// dx.doi.org/10.1111/j.1095-8339.1983.tb00720.x

Brongniart, A. 1822. Sur la classification et la distribution des végétaux fossiles en général, et sur ceux des terrains de sédiment supérieur en particulier. Mémoires Muséum d'Histoire naturelle de Paris, 8, pp. 203-348.

Brongniart, A. 1828a. Prodrome d'une Histoire des Végétaux Fossiles. Paris \& Strasbourg, F.G. Levrault, 225 p.

Brongniart, A. 1828b-1838. Histoire des végétaux fossiles, ou Recherches botaniques et géologiques sur les végétaux renfermés dans les diverses couches du globe. texte: I (1828-1837) - 1 (1828): i-xii, 1-80; 2 (1828): 81-136; 3 (1829): 137-168; 4 (1830): 169-208; 5 (1831): 209-248; 6 (1831): 249-264; 7 (1833): 265-288; 8 (1834): 289-312; 9 (1834): 313-316; 10 (1836): 337-368; 11 (1837): 369-416; 12 (1837): 417-488. II (1837-1838) - 13 (1837): 1-24; 14 (1838): 25-56; 15 (1838): 57-72; Atlas: I - Pls 1-166; II - Pls 1-30. Facsimile Edition W. Junk, Berlin (1915).

Brousmiche-Delcambre, C., Coquel, R., and Wagner, R.H. 1995. Nouvelle interprétation du genre Omphalophloios White, 1898 (Lycophyte primitive). Comptes rendus Académie des Sciences, Paris, 321, série IIa, pp. 179-184.

Bureau, M.E. 1913-1914. Bassin de la Basse Loire. Fascicule II: Decription des flores fossiles. Études des Gîtes minéraux de la France. Texte (1914): 1-417. Atlas (1913): pls I-LXXX.

Calder, J.H. 2007. Chronicle of a World Heritage Nomination: The Joggins Fossil Cliffs, Nova Scotia, Canada. In Mineral Resources Branch, Report of Activities 2006. Nova Scotia Department of Natural Resources, Report ME 2007-1, pp. $1-9$.

Calder, J.H. 2009. Designation of the Joggins Fossil Cliffs as a UNESCO World Heritage Site. In Mineral Resources Branch, Report of Activities 2008. Nova Scotia Department of Natural Resources, Report ME 2008-1, pp. $1-8$.

Calder, J.H., Gibling, M.R., Eble, C.F., Scott, A.C., and MacNeil, D.J. 1996. The Westphalian D fossil lepidodendrid forest at Table Head, Sydney Basin, Nova Scotia: Sedimentology, paleoecology and floral response to changing edaphic conditions. International Journal of Coal Geology, 31, pp. 277-313. http://dx.doi.org/10.1016/ S0166-5162(96)00020-1

Calder, J.H., Gibling, M.R., Scott, A.C., Davies, S.J., and Hebert, B.L. 2006. A fossil lycopsid forest succession in the classic Joggins section of Nova Scotia: Paleoecology of a disturbance-prone Pennsylvanian wetland. Geological Society of America, Special Paper 399, pp. 169-195.

Cambier, R. and Renier, A. 1912. Observations sur Cyclostigma Macconochiei Kidston sp. et Omphalophloios anglicus Sternberg sp. Annales de la Société géologique de 
Belgique, Mémoires in-4º 1911-1912, pp. 57-87.

Canright, J.E. 1959. Fossil plants of Indiana. Indiana Department of Conservation, Geological Survey, Report of Progress 14, pp. 1-45.

Carruthers, W. 1865. On an undescribed cone from the Carboniferous beds of Airdrie, Lanarkshire. Geological Magazine, 2, pp. 433-440. http://dx.doi.org/10.1017/ S0016756800162168

Chaloner, W.G. 1953. On the Megaspores of Four Species of Lepidostrobus. Annals of Botany, (New Series), XVII, 66, pp. 263-293.

Cleal, C.J. and Thomas, B.A. 1994. Plant Fossils of the British Coal Measures. Palaeontological Association, Field Guides to Fossils, 6, 222 p.

Cleal, C.J. and Thomas, B.A. 2001. The conservation of ancient tropical rain forests. In Biological Collections and Biodiversity. Edited by B.S. Rushton, P. Hackney and C.R. Tyrie, pp. 9-26.

Cleal, C.J., Laveine, J.-P., and Shute, C.H. 1996. Architecture of the Upper Carboniferous pteridosperm frond Macroneuropteris macrophylla. Palaeontology, 39 (3), pp. 561-582.

Cleal, C.J., Lazarus, M., and Townsend, A. 2005. Illustrations and illustrators during the "Golden Age" of palaeobotany: 1800-1840. In History of Palaeobotany: Selected Essays. Edited by A.J. Bowden, C.V. Burek and R. Wilding. Geological Society, London, Special Publications, 241, pp. 41-61.

Cridland, A.A., Morris, J.E., and Baxter, R.W. 1963. The Pennsylvanian plants of Kansas and their stratigraphic significance. Palaeontographica, Abt. B, 112 (1-3), pp. 58-92.

Crookall, R. 1964. Fossil Plants of the Carboniferous Rocks of Great Britain. (Second Section). Memoirs of the Geological Survey of Great Britain, Palaeontology, IV. Part 3 Lycopodiales: vii-xii, 217-354, Pls LIX-LXXXI, Text-figs. 73-106.

Crookall, R. 1966. Fossil Plants of the Carboniferous Rocks of Great Britain. (Second Section). Memoirs of the Geological Survey of Great Britain, Palaeontology, IV. Part 4 Lycopodiales: xiii-xx, 355-571, Pls LXXXII-CVI, Text-figs. 107-159.

Cross, A.T., Gillespie, W.H., and Taggart, R.E. 1996. Upper Paleozoic vascular plants. In Fossils of Ohio. Chapter 23. Department of Natural Resources, Division of Geological Survey, Bulletin 70, pp. 396-479.

Darrah, W.C. 1969. A critical review of the Upper Pennsylvanian floras of Eastern United States with notes on the Mazon Creek Flora of Illinois. Privately printed, Catalog Card Number 74-113602, Library of Congress, Washington, $220 \mathrm{p}$.

Dawson, J.W. 1862. On the Flora of the Devonian Period in North-eastern America. Quarterly Journal Geological Society of London, XVIII, p. 296-330. http://dx.doi.
org/10.1144/GSL.JGS.1862.018.01-02.42

Dawson, J.W. 1868. Acadian Geology. The Geological Structure, Organic Remains, and Mineral Resources of Nova Scotia, New Brunswick, and Prince Edward Island. London, $694 \mathrm{p}$.

Dawson, J.W. 1871. The Fossil Plants of the Devonian and Upper Silurian Formations. Geological Survey Canada, Report, 92 p. http://dx.doi.org/10.5962/bhl.title.38239

Dawson, J.W. 1873. Fossil Plants of the Lower Carboniferous and Millstone Grit Formations of Canada. Geological Survey of Canada, Report, $47 \mathrm{p}$.

Dawson, J.W. 1891. Acadian Geology. The Geological Structure, Organic Remains, and Mineral Resources of Nova Scotia, New Brunswick, and Prince Edward Island. London, 694 p. (Fourth edition, including supplements of 1878,103 p. and 1891,37 p.)

Dawson, J.W. 1897. On the Genus Lepidophloios as illustrated by Specimen from the Coal Formation of Nova Scotia and New Brunswick. Transactions Royal Society of Canada, Second Series, 1897-98, IV (III), pp. 57-105.

Deltenre, H. 1924-1926. Les Sigillaires des Charbonnages de Mariemont. Mémoires de l'Institut Géologique de l'Université de Louvain, III, pp. 1-116.

Dijkstra, S.J. and Amerom, H.W.J. van 1991. Fossilium Catalogus. II: Plantae. Pars 94: Lycopodiales X. 2. Supplement. Kugler Publications, Amsterdam, pp. 1-127.

Dijkstra, S.J. and Amerom, H.W.J. van 1994. Fossilium Catalogus. II: Plantae. Pars 95: Lycopodiales XI. 2. Supplement und Nachtrag zum 2. Supplement. Kugler Publications, Amsterdam, pp. 129-296.

Dilcher, D.L. and Lott, T.A. 2005. Atlas of Union Chapel Mine Fossil Plants. In Pennsylvanian Footprints in the Black Warrior Basin of Alabama. Edited by R.J. Buta, A.K. Rindsberg and D.C. Kopaska-Merkel. Alabama Paleontological Society, Monograph, 1, pp. 339-365.

Dilcher, D.L., Lott, T.A., and Axsmith, B.J. 2005. Fossil Plants from the Union Chapel Mine, Alabama. In Pennsylvanian Footprints in the Black Warrior Basin of Alabama. Edited by R.J. Buta, A.K. Rindsberg, and D.C. Kopaska-Merkel. Alabama Paleontological Society, Monograph, 1, pp. 153168.

DiMichele, W.A. 1979. Arborescent lycopods of Pennsylvanian age coals: Lepidophloios. Palaeontographica, Abt. B, 171 (1-3), pp. 57-77.

DiMichele, W.A. 1980. Paralycopodites Morey \& Morey, from the Carboniferous of Euramerica - A reassessment of generic affinities and evolution of "Lepidodendron" brevifolium Williamson. American Journal of Botany, 67 (10), pp. 1466-1476. http://dx.doi.org/10.2307/2442875

DiMichele, W.A. 1983. Lepidodendron hickii and Generic Delimitation in Carboniferous Lepidodendrid Lycopods. Systematic Botany, 8 (3), pp. 317-333. http://dx.doi. org/10.2307/2418485

DiMichele, W.A. 1985. Diaphorodendron, gen. nov., a 
Segregate from Lepidodendron (Pennsylvanian Age). Systematic Botany, 10 (4), pp. 453-458. http://dx.doi. org/10.2307/2419138

DiMichele, W.A. and Bateman, R.M. 1992. Diaphorodendraceae, fam. nov. (Lycopsida: Carboniferous): systematics and evolutionary relationships of Diaphorodendron and Synchysidendron, gen. nov. American Journal of Botany, 79 (6), pp. 605-617. http:// dx.doi.org/10.2307/2444876

DiMichele, W.A. and Beall, B.S. 1990. Flora, fauna, and paleoecology of the Brazil Formation of Indiana. Rocks \& Minerals, 65, pp. 244-250.

DiMichele, W.A. and DeMaris, P.J. 1987. Structure and Dynamics of a Pennsylvanian-Age Lepidodendron Forest: Colonizers of a Disturbed Swamp Habitat in the Herrin (No. 6) Coal of Illinois. Palaios, 2, pp. 146-157. http:// dx.doi.org/10.2307/3514642

DiMichele, W. and Dolph, G. 1981. Compression Floras of the Upper Mansfield/Lower Brazil and Upper Staunton Formation in Parke and Clay Counties, Indiana. Thirtysecond Annual AIBS Meeting, Field Trip 2, Guidebook to Pennsylvanian Plant Localities, pp. 1-6.

DiMichele, W.A. and Falcon-Lang, H.J. 2011. Pennsylvanian "fossil forests" in growth position ( $\mathrm{T}^{0}$ assemblages): origin, taphonomic bias and palaeoecological insights. Journal of the Geological Society, London, 168, pp. 585-605. http:// dx.doi.org/10.1144/0016-76492010-103

DiMichele, W.A. and Phillips, T.L. 1985. Arborescent lycopod reproduction and paleoecology in a coal-swamp environment of late Middle Pennsylvanian age (Herrin Coal, Illinois, U.S.A.). Review of Palaeobotany and Palynology, 44, pp. 1-26. http://dx.doi.org/10.1016/00346667(85)90026-0

DiMichele, W.A. and Phillips, T.L. 1994. Paleobotanical and paleoecological constraints on models of peat formation in the Late Carboniferous of Euramerica. Palaeogeography, Palaeoclimatology, Palaeoecology, 106, pp. 39-90. http:// dx.doi.org/10.1016/0031-0182(94)90004-3

DiMichele, W.A., Eble, C.F., and Chaney, D.S. 1996. A drowned lycopsid forest above the Mahoning coal (Conemaugh Group, Upper Pennsylvanian) in eastern Ohio, U.S.A. International Journal of Coal Geology, 31, pp. 249-276. http://dx.doi.org/10.1016/S01665162(96)00019-5

DiMichele, W.A., Elrick, S.D., and Bateman, R.M. 2013. Growth habit of the late Paleozoic rhizomorphic treelycopsid family Diaphorodendraceae: phylogenetic, evolutionary, and paleoecological significance. American Journal of Botany, 100 (8), pp. 1604-1625. http://dx.doi. org/10.3732/ajb.1200623

Eggert, D.L. 1961. The ontogeny of Carboniferous arborescent Lycopsida. Palaeontographica, Abt. B, 108 (3-6), pp. 43-92.

Eggert, D.L. and Phillips, T.L. 1982. Environments of
Deposition - Coal Balls, Cuticular Shale, and Gray-Shale Floras in Fountain and Parke Counties, Indiana. State of Indiana, Department of Natural Resources, Geological Survey, Special Report 30, pp. 1-43.

Ettingshausen, C. von 1854. Die Steinkohlenflora von Radnitz in Böhmen. Abhandlungen der kaiserlichenköniglichen geologischen Reichsanstalt, Bd. II, 3 Abtheilung, no 3, pp. 1-74.

Fairchild, H.L. 1877. The Variation of the leaf-scars of Lepid. aculeatum Sternb. Annals New York Academy of Sciences, I, pp. 77-91.

Falcon-Lang, H.J. 2006. Vegetation ecology of Early Pennsylvanian alluvial fan and piedmont environments in southern New Brunswick, Canada. Palaeogeography, Palaeoclimatology, Palaeoecology, 233, pp. 34-50. http:// dx.doi.org/10.1016/j.palaeo.2005.09.005

Falcon-Lang, H.J. and Miller, R.F. 2007. Palaeoenvironments and palaeoecology of the Early Pennsylvanian Lancaster Formation ("Fern Ledges") of Saint John, New Brunswick, Canada. Journal of the Geological Society, London, 164, pp. 945-957. http://dx.doi.org/10.1144/0016-76492006189

Falcon-Lang, H.J., Rygel, M.C., Calder, J.H., and Gibling, M.R. 2004. An early Pennsylvanian waterhole deposit and its fossil biota in a dryland alluvial plain setting, Joggins, Nova Scotia. Journal of the Geological Society, London, 161, pp. 209-222. http://dx.doi.org/10.1144/0016764903-109

Feistmantel, O. 1875. Die Versteinerungen der böhmischen Kohlenablagerungen. In Beiträge zur Naturgeschichte der Vorwelt. Palaeontographica, XXIII (4-6), pp. 173-222.

Feistmantel, O. 1876. Die Versteinerungen der böhmischen Kohlenablagerungen. In Beiträge zur Naturgeschichte der Vorwelt. Palaeontographica, XXIII (7), pp. 223-262.

Fischer, F.F. 1905a. Lepidodendron obovatum Sternberg. In Abbildungen und Beschreibungen fossiler PflanzenReste. Edited by $\mathrm{H}$. Potonié. Königliche Preußische Geologische Landesanstalt, Lieferung III, 48, pp. 1-11.

Fischer, F.F. 1905b. Lepidodendron - Erhaltungszustand. Bergeria Presl zum Teil. In Abbildungen und Beschreibungen fossiler Pflanzen-Reste. Edited by H. Potonié. Königliche Preußische Geologische Landesanstalt, Lieferung III, 42, pp. 1-12.

Gastaldo, R.A. 1977. A Middle Pennsylvanian nodule flora from Carterville, Illinois. In Geobotany. Edited by R.C. Romans. Plenum Publishing Corporation, New York, pp. 133-155. http://dx.doi.org/10.1007/978-1-4757-1674$0 \_8$

Gastaldo, R.A. 1985. Upper Carboniferous paleoecological reconstructions: observations and reconsiderations. Dixième Congrès International de Stratigraphie et de Géologie du Carbonifère, Madrid 1983, Compte Rendu 2, pp. 281-296.

Gibling, M.R., Culshaw, N., Rygel, M.C., and Pascucci, V. 
2008. The Maritimes Basin of Atlantic Canada: Basin Creation and Destruction in the Collisional Zone of Pangea. In The Sedimentary Basins of the United States and Canada. Edited by Andrew Miall. Sedimentary Basins of the World, 5, pp. 211-244.

Gillespie, W.H. and Clendening, J.A. 1962. A Lower Kittanning Flora From Northern West Virginia. Proceedings of West Virginia Academy of Science, 34, pp. 125-132.

Gillespie, W.H. and Crawford, T.J. 1985. Plant megafossils from the Carboniferous of Georgia, U.S.A. Dixième Congrès International de Stratigraphie et de Géologie du Carbonifère, Madrid 1983, Compte Rendu 2, pp. 247-256.

Gillespie, W.H. and Latimer, I.S. 1960. A guide to the common fossil plants of West Virginia. West Virginia Geological and Economic Survey, Educational Series, June 1960, pp. 1-59.

Gillespie, W.H. and Rheams, L.J. 1985. Plant megafossils from the Carboniferous of Alabama, U.S.A. Dixième Congrès International de Stratigraphie et de Géologie du Carbonifère, Madrid 1983, Compte Rendu 2, pp. 191-202.

Gillespie, W.H., Latimer, I.S., and Clendening, J.A. 1966. Plant Fossils of West Virginia. West Virginia Geological and Economic Survey, Educational Series, pp. 1-131.

Gillespie, W.H., Clendening, J.A., and Pfefferkorn, H.W. 1978. Plant Fossils of West Virginia and Adjacent Areas. West Virginia Geological and Economic Survey, Educational Series ED-3A, pp. 1-172.

Gillespie, W.H., Crawford, T.J., and Waters, J.A. 1989. Plant fossils of the Pennsylvanian System of Georgia. 38 $8^{\text {th }}$ Annual Meeting, Southeastern Section, The Geological Society of America, Guidebook Addendum, pp. 1-13.

Goldenberg, F. 1855-1862. Flora Saraepontana fossilis. Die Pflanzenversteinerungen des Steinkohlengebirges von Saarbrücken. Heft I (1855): Die Selagineen der Vorwelt. Ein Beitrag zur näheren Kenntniss der Flora der Steinkohlenperiode, pp. 1-38, Taf. A-B, I-IV. Heft II (1857): Die Sigillarien des Kohlengebirges, in analytischer, beschreibender und bildlicher Darstellung, pp. 1-60, Taf. V-X. Heft III (1862): Die fossilen Gattungen Stigmaria, Diploxylon, Lomatophloyos und Lepidophloyos enthaltend, pp. 1-47, Taf. XI-XVI.

Gómez de Llarena, J. 1950. Nuevos datos geológicos y paleontológicos sobre la cuenca carbonífera de CiñeraMatallana (León). Estudios Geológicos, VI (11), pp. 5397.

Göppert, H.R. 1836. Die Fossilen Farrnkräuter. Verhandlungen der Kaiserlichen LeopoldinischCarolinischen Akademie der Naturforscher, XVII Suppl., $486 \mathrm{p}$.

Hirmer, M. 1927. Handbuch der Paläobotanik. Band I: Thallophyta-Bryophyta-Pteridophyta. Verlag R. Oldenbourg, München und Berlin, 708 p.

Janssen, R.E. 1940. Some Fossil Plant Types of Illinois.
A Restudy of the Lesquereux Types in the Worthen Collection of the Illinois State Museum, Augmented By Descriptions of New Species From Mazon Creek. Illinois State Museum, Scientific Papers, I, pp. 1-124.

Janssen, R.E. 1957. Leaves and Stems from Fossil Forests. A Handbook of the Paleobotanical Collections in the Illinois State Museum. Illinois State Museum, Popular Science Series, I, pp. 1-190. (First printing, 1939)

Jennings, J.R. 1970. Preliminary report on fossil plants from the Chester Series (Upper Mississippian) of Illinois. The Transactions of the Illinois State Academy of Science, 63 (2), pp. 167-177.

Jennings, J.R. 1974. Lower Pennsylvanian plants of Illinois. I: A flora from the Pounds Sandstone Member of the Caseyville Formation. Journal of Paleontology, 48 (3), pp. 459-473.

Jennings, J.R. 1980. Fossil plants from the Fountain Formation (Pennsylvanian) of Colorado. Journal of Paleontology, 54 (1), pp. 149-158.

Jennings, J.R. 1984. Distribution of Fossil Plant Taxa in the Upper Mississippian and Lower Pennsylvanian of the Illinois Basin. Neuvième Congrès International de Stratigraphie et Géologie du Carbonifère, Washington and Champaign-Urbana 1979, Compte Rendu 2, pp. 301-312.

Jongmans, W.J. 1909. The flora of the Dutch Carboniferous compared with that of the adjacent coalfields. In The deeper geology of The Netherlands and adjacent regions, with special reference to the latest borings in The Netherlands, Belgium and Westphalia. Edited by W.A.J.M. van Waterschoot van der Gracht. Memoirs of the Government Institute for the Geological Exploration of The Netherlands (Rijksopsporing van Delfstoffen), 2, pp. 162-247.

Jongmans, W.J. 1929. Fossilium Catalogus. II: Plantae. Pars 15: Lycopodiales II. Ed. W. Junk, Berlin, pp. 55-525.

Jongmans, W.J. 1930. Fossilium Catalogus. II: Plantae. Pars 16: Lycopodiales III (incl. Hydropterideae, Psilophytales, Sphenophyllales). Ed. W. Junk, Berlin, pp. 329-650.

Jongmans, W.J. 1932. Fossilium Catalogus. II: Plantae. Pars 18: Lycopodiales IV (incl. Hydropterideae, Psilophytales, Sphenophyllales). Ed. W. Junk, Berlin, pp. 653-996.

Jongmans, W.J. 1936. Fossilium Catalogus. II: Plantae. Pars 21: Lycopodiales V (incl. Hydropterideae, Psilophytales, Sphenophyllales), Ed. W. Junk, Berlin, pp. 999-1188.

Jongmans, W.J. 1937. Comparison of the floral succession in the Carboniferous of West Virginia with Europe. Deuxième Congrès pour l'avancement des études de Stratigraphie Carbonifère, Heerlen 1935, Compte Rendu I, pp. 393-415.

Jongmans, W.J. and Dijkstra, S.J. 1969. Fossilium Catalogus. II: Plantae. Pars 72-73: Lycopodiales VII. Supplement. Ed. W. Junk, Netherlands, pp. 1333-1547.

Jonker, F.P. 1976. The Carboniferous "genera" Ulodendron 
and Halonia - An assessment. Palaeontographica, Abt. B, 157 (5-6), pp. 97-111.

Josten, K.-H. 1991. Die Steinkohlen-Floren Nordwestdeutschlands. Fortschritte Geologie von Rheinland und Westfalen, 36. Textband: 434 p., Tab. 1-29, Tafelband: 11 p., Tafn 1-220.

Josten, K.-H. and Amerom, H.W.J. van 2003. Die Flora des Namur B aus Hagen-Vorhalle. Geologie und Paläontologie in Westfalen, 61, pp. 5-303.

Kidston, R. 1883. Report on Fossil Plants collected by the Geological Survey of Scotland in Eskdale and Liddesdale. Transactions of the Royal Society of Edinburgh, XXX, pp. 531-550.

Kidston, R. 1886. Catalogue of the Palaeozoic Plants in the Department of Geology and Palaeontology, British Museum (Natural History). Harrison and Sons, London, $288 \mathrm{p}$.

Kidston, R. 1890. The Yorkshire Carboniferous Flora. First Report. Transactions of the Yorkshire Naturalists' Union, 14, pp. 1-64.

Kidston, R. 1891. Notes on the Palaeozoic Species mentioned in Lindley and Hutton's "Fossil Flora". Proceedings of the Royal Physical Society, Edinburgh, X, pp. 345-391.

Kidston, R. 1893. On the Fossil Plants of the Kilmarnock, Galston, and Kilwinning Coal Fields, Ayrshire. Transactions of the Royal Society of Edinburgh, XXXVII, part II (16), pp. 307-358.

Kidston, R. 1901. Carboniferous Lycopods and Sphenophylls. Transactions Natural History Society of Glasgow (New Series), VI (1899-1902), pp. 25-140.

Kidston, R. 1902. The Flora of the Carboniferous Period. Second Paper. Proceedings of the Yorkshire Geological and Polytechnic Society, New Series, XIV (III), pp. 344400.

Kidston, R. 1903. The Fossil Plants of the Carboniferous Rocks of Canonbie, Dumfriesshire, and of Parts of Cumberland and Northumberland. Transactions of the Royal Society of Edinburgh, XL, Part IV (31), pp. 741833.

Kidston, R. 1911. Les végétaux houillers recueillis dans le Hainaut Belge et se trouvant dans les Collections du Musée royal d'Histoire naturelle à Bruxelles. Imprimerie Polleunis \& Ceuterick, Bruxelles, 282 p.

Kidston, R. 1916. Contributions to our Knowledge of British Palaeozoic Plants. Part I. Fossil Plants from the Scottish Coal Measures. Transactions of the Royal Society of Edinburgh, LI, Part III (22), pp. 709-720.

Klusemann, H. von and Teichmüller, R. 1954. Bergrabene Wälder im Ruhrkohlenbecken. Natur und Volk, 84 (11), pp. 373-382.

Kosanke, R.M. 1979. A long-leaved specimen of Lepidodendron. Geological Society of America Bulletin, 90, pp. 431-434 http://dx.doi.org/10.1130/00167606(1979)90<431:ALSOL>2.0.CO;2.
Kvaček, Z. and Kvaček, J. 1992. Šternberkovo dílo Flora der Vorwelt, jeho význam a stav dokladové sbírky. (Sternberg's work Flora der Vorwelt, its significance and the state of the original collection). Časopis Národního Muzea v Praze, 158 (1-4), pp. 31-42.

Kvaček, J. and Straková, M. 1997. Catalogue of fossil plants described in works of Kaspar M. Sternberg. National Museum, Prague, $201 \mathrm{p}$.

Langford, G. 1958. The Wilmington Coal Flora From a Pennsylvanian Deposit in Will County, Illinois. Earth Science Club of Northern Illinois, Esconi Associates, Illinois, $360 \mathrm{p}$.

Langford, G. 1963. The Wilmington Coal Fauna and Additions to the Wilmington Coal flora From a Pennsylvanian Deposit in Will County, Illinois. Earth Science Club of Northern Illinois, Esconi Associates, Illinois, $280 \mathrm{p}$.

Laveine, J.-P., Zhang, S., Liu, L., Gu, F., Liu, Y., Wen, J., and Lemoigne, Y. 2003. The Late Carboniferous floras of the Delingha area (Wulan County, Qinghai Province, Northwest China). Revue Paléobiologie, Genève, 22 (2), pp. 567-651.

Leary, R.L. and Pfefferkorn, H.W. 1977. An Early Pennsylvanian Flora with Megalopteris and Noeggerathiales from West-Central Illinois. Illinois State Geological Survey, Circular 500, pp. 1-77.

Leary, R.L. and Thomas, B.A. 1989. Lepidodendron aculeatum with attached foliage: evidence of stem morphology and fossilization processes. American Journal of Botany, 76 (2), pp. 283-288. http://dx.doi.org/10.2307/2444670

Lesquereux, L. 1858. Fossil Plants of the Coal Strata of Pennsylvania. In The Geology of Pennsylvania, II (Pt. II). Edited by H.D. Rogers, pp. 835-884.

Lesquereux, L. 1860. Botanical and Paleontological Report on the Geological State Survey of Arkansas. In D.D. Owen, Second Report of a Geological Reconnaissance of the Middle and Southern Counties of Arkansas, 308-317; Philadelphia.

Lesquereux, L. 1866. An Enumeration of the Fossil Plants Found in the Coal Measures of Illinois, With Descriptions of the New Species. Geological Survey of Illinois, Paleontology, II, pp. 427-470.

Lesquereux, L. 1870. Report on the Fossil Plants of Illinois. In Geological Survey of Illinois. IV. Geology and Paleontology. Edited by A.H. Worthen. Part I: A.H. Worthen, H.M. Bannister, F.H. Bradley and H.A. Green. Geology, pp. 1-342. Part II: Paleontology of Illinois; Section I. J.S. Newberry \& A.H. Worthen. Description of Fossil Vertebrates, pp. 346-374, pls I-IV; Section II. L. Lesquereux. Description of Plants, pp. 377-508, pls VXXXI.

Lesquereux, L. 1879-1884. Description of the Coal Flora of the Carboniferous Formation in Pennsylvania and throughout the United States. Second Geological Survey 
Pennsylvania, Report of Progress. Text - I (1880): pp. 1-354; II (1880): pp. 355-694, i-lxiii, pls LXXXVI, LXXXVII; III (1884): pp. 695-977, pls LXXXVIII-CXI. Atlas (1879): pls A, B; pls I-LXXXV.

Lindley, J. and Hutton, W. 1831-1837. The Fossil Flora of Great Britain; or, Figures and Descriptions of the Vegetable Remains found in a Fossil State in this Country. I (1831-1833) - 1831: 1-47, pls 1-14; 1832: 48-166, pls 15-59; 1833: 167-224, pls 60-79; II (1833-1835) - 1833: 1-56, pls 80-99; 1834: 57-156, pls 100-137; 1835: 157-208, pls 138-156; III (1835-1837) - 1835: 1-72, pls 157-176; 1836: 73-122, pls 177-194; 1837: 123-208, pls 195-230. James Ridgway and Sons, London.

Lucas, S.G., DiMichele, W.A., Krainer, K., Chaney, D.S., and Spielmann, J.A. 2009. A coal-measure forest near Socorro, New Mexico. New Mexico Geological Society Guidebook, $60^{\text {th }}$ Field Conference, Geology of the Chupadera Mesa Region, pp. 235-242.

Lucas, S.G., Nelson, W.J., DiMichele, W.A., Krainer, K. Barrick, J.E., Voigt, S., Chaney, D.S., Elrick, S., and Spielmann, J.A. 2013. Field guide to the Carboniferous transition in the Cerros de Amado and vicinity, Socorro County, central New Mexico. In The CarboniferousPermian transition in central New Mexico. Edited by S.G. Lucas, W.J. Nelson, W.A. DiMichele et al. New Mexico Museum of Natural History \& Science, 59, pp. 39-76.

Lyell, C. and Dawson, J.W. 1853. On the Remains of a Reptile (Dendrerpeton acadianum Wyman and Owen), and of a Land Shell Discovered in the Interior of an Erect Fossil Tree in the Coal Measures of Nova Scotia. Quarterly Journal of the Geological Society of London, 9, pp. 58-63. http://dx.doi.org/10.1144/GSL.JGS.1853.009.01-02.19

Lyons, P.C. 1984. Carboniferous Megafloral Zonation of New England. Neuvième Congrès International de Stratigraphie et Géologie du Carbonifère, Washington and Champaign-Urbana 1979, Compte Rendu 2, pp. 503-514.

Lyons, P.C. and Chase, H.N. 1976. Coal stratigraphy and flora of the northwestern Narragansett Basin. In Geology of Southeastern New England. Edited by B. Cameron. Guidebook for Field Trips to the Boston Area and Vicinity, Trip B-18, New England Intercollegiate Geological Conference, $68^{\text {th }}$ Annual Meeting, pp. 405-425.

Lyons, P.C. and Darrah, W.C. 1979. Fossil floras of Westphalian D and early Stephanian age from the Narragansett Basin, Massachusetts and Rhode Island. In Carboniferous Basins in Southeastern New England. Edited by B. Cameron. Field Trip Guidebook no 5, Ninth International Congress on Carboniferous Stratigraphy and Geology, pp. 81-89.

Lyons, P.C., Meissner, C.R., Barwood, H.L., and Adinolfi, F.G. 1985. North American and European megafloral correlations with the upper part of the Pottsville Formation of the Warrior coal field; Alabama, U.S.A.
Dixième Congrès International de Stratigraphie et Géologie du Carbonifère, Madrid 1983, Compte Rendu 2, pp. 203-245.

Němejc, F. 1946. Further critical remarks on Sternberg's Lepidodendron dichotomum and its relations to the cones of Sporangiostrobus Bode. Bulletin international de l'Académie tchèque des Sciences, 7, pp. 1-10.

Němejc, F. 1947. The Lepidodendraceae of the coaldistricts of Central Bohemia. (A preliminary study). Sborník Národního Musea v Praze (Acta Musei Nationalis Pragae), III B (2), pp. 45-87.

Nermejc, F. 1954. Taxonomical studies on the strobili of the Lepidodendraceae of the coal districts of central Bohemia. Sborník Národního Musea v Praze (Acta Musei Nationalis Pragae), X, B, 5, pp. 1-83.

Němejc, F. 1963. Paleobotanika II. Nakladatelstvi Československé Akademie Věd, Praha, 529 p. (In Czech).

Noé, A.C. 1925. Pennsylvanian flora of northern Illinois. Illinois State Geological Survey, Bulletin, 52, pp. 1-113.

Oleksyshyn, J. 1982. Fossil plants from the Anthracite Coal Fields of Eastern Pennsylvania. Pennsylvania Geological Survey, General Geology Report 72, pp. 1-157.

Opluštil, S. 2010. Contribution to knowledge on ontogenetic developmental stages of Lepidodendron mannebachense Presl, 1838. Bulletin of Geosciences, 85 (2), pp. 303-316. http://dx.doi.org/10.3140/bull.geosci.1180

Opluštil, S., Pšenička, J., Libertín, M., Bashforth, A.R., Šimůnek, Z., Drábková, J., and Dašková, J. 2009. A Middle Pennsylvanian (Bolsovian) peat-forming forest preserved in situ in volcanic ash of the Whetstone Horizon in the Radnice Basin, Czech Republic. Review of Palaeobotany and Palynology, 155 (3-4), pp. 234-274. http://dx.doi. org/10.1016/j.revpalbo.2009.03.002

Parkinson, J. 1804. Organic Remains of a Former World. Sherwood, Meety \& Jones, London, $471 \mathrm{p}$.

Pearson, H.L. 1986. Structure and taxonomy of the Carboniferous lycopsid Anabathra. Bulletin British Museum natural History (Geology), 40 (5), pp. 265-292.

Peppers, R.A. 1996. Palynological Correlation of Major Pennsylvanian (Middle and Upper Carboniferous) Chronostratigraphic Boundaries in the Illinois and Other Coal Basins. Geological Society of America, Memoir 188, pp. 1-111.

Phillips, T.L. and DiMichele, W.A. 1992. Comparative ecology and life-history biology of arborescent lycopsids in late Carboniferous swamps of Euramerica. Annals of the Missouri Botanical Garden, 79 (3), pp. 560-588. http://dx.doi.org/10.2307/2399753

Ramsbottom, W.H.C., Calver, M.A., Eagar, R.M.C., Hodson, F., Holliday, D.W., Stubblefield, C.J., and Wilson, R.B. 1978. A correlation of Silesian Rocks in the British Isles. Geological Society of London, Special Report No. 10, pp. $1-82$.

Read, C.B. and Mamay, S.H. 1964. Upper Paleozoic Floral 
Zones and Floral Provinces of the United States. Shorter Contributions to General Geology. Geological Survey Professional Paper 454-K, pp. K1-K35.

Remy, W. and Remy, R. 1959. Pflanzenfossilien. Ein Führer durch die Flora des limnisch entwickelten Paläozoikums. Akademie Verlag, Berlin, 285 p.

Renier, A. 1910. Documents pour l'étude de la Paléontologie du Terrain Houiller. Imprimérie H. Vaillant-Carmanne, Liège, pp. 1-26, pls 1-118.

Renier, A., Stockmans, F., Demanet, F. and Straelen, V. van. 1938. Flore et Faune houillères de la Belgique. Introduction à l'étude paléontologique du terrain houiller. Musée royal d'Histoire naturelle de Belgique, Bruxelles. Texte: 1-317; Planches: 1-49, pls 1-144.

Roehl, D. von 1868. Fossile Flora der Steinkohlen-Formation Westphalens einschliesslich Piesberg bei Osnabrück. Palaeontographica, XVIII (4-6), pp. 1-192.

Rothwell, G.W. 1984. The apex of Stigmaria (Lycopsida), rooting organ of Lepidodendrales. American Journal of Botany, 71 (8), pp. 1031-1034. http://dx.doi. org/10.2307/2443377

Rothwell, G.W. and Pryor, J.S. 1991. Developmental dynamics of arborescent lycophytes - apical and lateral growth in Stigmaria ficoides. American Journal of Botany, 78 (12), pp. 1740-1745. http://dx.doi.org/10.2307/2444853

Sauveur 1848. Végétaux fossiles des terrains houillers de la Belgique. Mémoires de l'Académie Royale des Sciences, des Lettres et des Beaux-Arts de Belgique, pls I-XXXVI.

Schimper, W.P. 1870. Traité de Paléontologie végétale ou la flore du monde primitif dans ses rapports avec les formations géologiques et la flore du monde actuel. Tome Seconde. Paris, Baillière et fils, libraires de l'Académie de Médecine, $966 \mathrm{p}$.

Schlotheim, E.F. von 1820. Die Petrefactenkunde auf ihrem jetztigen Standpunkte, durch die Beschreibung seiner Sammlung versteinerter und fossiler Überreste des Thierund Pflanzenreichs der Vorwelt erläutert. Gotha, i-lxii (Einleitung), 437 p., Tafn I-XXXVI (Nachträge in 1822; i-xi, 100 p. und 1823,114 p.).

Scott, A.C. and Calder, J.H. 1994. Carboniferous fossil forests. Geology Today, 10 (6), pp. 213-217. http://dx.doi. org/10.1111/j.1365-2451.1994.tb00992.x

Snigirevskaya, S.N. 1958. Anatomical investigation of fossil leaves (phylloids) of certain Lycopsida in coal balls of the Donetz coalfields. Botanical Zhurnal, S.S.S.R., XLIII (1), pp. 106-112.

Sternberg, K. von 1820-1838. Versuch einer geognostischbotanischer Darstellung der Flora der Vorwelt. I (18201825) 1 (1820): 1-24, Tafn I-XIII; 2 (1823): 1-33, Tafn XIV-XXVI; 3 (1824): 1-40, Tafn XXVII-XXXIX; 4 (1825): 1-48, Tafn XL-LIX, Tafn A-E. II (1833-1838) - 5/6 (1833): 1-80, Tafn I-XXVI; 7/8 (1838, Presl): 81-220, Tafn I-LXVIII, Tafn A, B (incl. Corda: Skizzen zur vergleichenden Phytotomie vor- und jetztweltlicher
Pflanzenstämme, I-LXXI).

Stockmans, E. 1935. Au sujet de Lepidodendron dissitum Sauveur. Bulletin du Musée royal d'Histoire naturelle de Belgique, XI (28), pp. 1-8.

Stockmans, F. and Willière, Y. 1952. Quelques végétaux namuriens de la Galerie de Ben. In Étude géologique du Gisement Houiller d'Andenne-Huy. Le Namurien dans le Bassin d'Andenne. Edited by W. van Leckwyck, F. Demanet, Y. Willière. and H. Chaudoir. Association pour l'Étude de la Paléontologie et de la Stratigraphie Houillères, Bruxelles, 11, pp. 1-107, pls A-F.

Stockmans, F. and Willière, Y. 1960. Trois Lepidodendron nouveaux du Bassin Houiller de la Campine. In Stratigraphie et sedimentologie de la zone de Genk aux charbonnages de Helchteren et Zolder, Zwartberg et Winterslag (Campine). Edited by J. Scheere. Mémoires de l'Institut Géologique de l'Université de Louvain, XXII (1959), pp. 305-309, pls XIII, XIV.

Stockmans, F. and Willière, Y. 1965. Documents paléobotaniques pour létude du houiller dans le NordOuest de l'Espagne. (Documentos paleobotánicos para el estudio de la geología hullera del Noroeste de España). Mémoires, Institut Royal des Sciences Naturelles de Belgique, Deuxième Série, fasc. 79, pp. 1-92.

Stopes, M.C. 1914. The "Fern Ledges" Carboniferous Flora of St. John, New Brunswick. Geological Survey of Canada, Memoir 41 (38 of Geological Series), pp. 11-42, pls IXXV. (Traduction française 1917. Flore carbonifère des "assises à fougères" de Saint-Jean, Nouveau-Brunswick. Geological Survey of Canada, Memoir 41.)

Taylor, T.N., Taylor, E.L., and Krings, M. 2009. Paleobotany. The Biology and Evolution of Fossil Plants. Academic Press, $1230 \mathrm{p}$.

Teichmüller, R. 1955. Über Küstenmoore der Gegenwart und die Moore des Ruhrkarbons. Eine vergleichende sedimentologische Betrachtung. Geologisches Jahrbuch, 71, pp. 197-220.

Tenchov, Y.G. 1987. Les fossiles de Bulgarie. I.1. Paléozoïque. Flore fossile. Megaflore. 1. Sphenopsida et Lycopsida. Editions de l'Académie Bulgare des Sciences, $165 \mathrm{p}$.

Thomas, B.A. 1967. Ulodendron: Lindley and Hutton and its Cuticle. Annals of Botany, 31 (124), pp. 775-782.

Thomas, B.A. 1968. The carboniferous fossil lycopod Ulodendron landsburgii (Kidston) comb. nov. Journal of natural History, 2, pp. 425-428. http://dx.doi. org/10.1080/00222936800770401

Thomas, B.A. 1970. Epidermal studies in the interpretation of Lepidodendron species. Palaeontology, 13 (1), pp. 145173.

Thomas, B.A. 1977. Epidermal studies in the interpretation of Lepidophloios species. Palaeontology, 20 (2), pp. 273293.

Tidwell, W.D. 1967. Flora of Manning Canyon Shale. Part I: A Lowermost Pennsylvanian Flora from the Manning 
Canyon Shale, Utah, and Its Stratigraphic Significance. Brigham Young University Geology Studies, 14, pp. 1-66.

Tidwell, W.D. 1975. Guide to the common fossil plants of western North America. Brigham Young University Press, Utah, $197 \mathrm{p}$.

Tidwell, W.D. 1978. Guide to the common fossil plants of western North America. Brigham Young University Press, Utah, 299 p. (Second edition)

Tidwell, W.D., Medlyn, D.A., and Simper, A.D. 1974. Flora of the Manning Canyon Shale. Part II: Lepidodendrales. Brigham Young University Geology Studies, 21 (3), pp. 119-146.

Tidwell, W.D., Jennings, J.R., and Beus, S.S. 1992. A Carboniferous flora from the Surprise Canyon Formation in the Grand Canyon, Arizona. Journal of Paleontology, 66 (6), pp. 1013-1021.

Wagner, R.H. 1959. Flora fósil y estratigrafía del Carbonífero de España NW. y Portugal N. Estudios Geológicos, XV, pp. 393-420.

Wagner, R.H. 1965. Palaeobotanical Dating of Upper Carboniferous Folding Phases in NW. Spain. Memorias Instituto Geológico y Minero de España, LXVI, 1-169.

Wagner, R.H. 1999. Macrofloras del Carbonífero/Pérmico. In La huella del pasado. Fósiles de Castilla-La Mancha. Patrimonio histórico. Arqueología. Coordinated by E. Aguirre and I. Rábano. Castilla-La Mancha, Junta de Comunidades de Castilla-La Mancha, pp. 75-98.

Wagner, R.H. 2001. The extrabasinal elements in lower Pennsylvanian floras of the Maritime Provinces, Canada: description of Adiantites, Pseudadiantites and Rhacopteridium. Revista Española de Paleontología, 16 (2), pp. 187-207.

Wagner, R.H. 2005a. Dicranophyllum glabrum (Dawson) Stopes, an unusual element of lower Westphalian floras in Atlantic Canada. Revista Española de Paleontología, 20 (1), pp. 7-13.

Wagner, R.H. 2005b. Alethopteris lancifolia Wagner, a rare element of lower Westphalian "Fern Ledges" of Atlantic Canada. Revista Española de Paleontología, 20 (1), pp. 15-19.

Wagner, R.H. 2008. Laveineopteris polymorpha from the lower Westphalian (Langsettian) "Fern Ledges" at Saint John, New Brunswick, Canada, and comparison with Laveineopteris hollandica from Europe. Revista Española de Paleontología, 23 (2), pp. 139-156.

Wagner, R.H. and Álvarez-Vázquez, C. 2008. A revision of the lower Pennsylvanian Alethopteris lonchitica (auctorum) and its identity with Alethopteris urophylla. Revista Española de Paleontología, 23 (2), pp. 157-192.

Wagner, R.H. and Álvarez-Vázquez, C. 2010. The Carboniferous floras of the Iberian Peninsula: A synthesis with geological connotations. Review of Palaeobotany and Palynology, 162 (3), pp. 238-324. http://dx.doi. org/10.1016/j.revpalbo.2010.06.005
Wagner, R.H. and Diez, J.B. 2007. Verdeña (Spain): Life and death of a Carboniferous forest community. Comptes rendus Palevol, 6, pp. 495-504. http://dx.doi. org/10.1016/j.crpv.2007.09.021

Wagner, R.H. and Lyons, P.C. 1997. A critical analysis of the higher Pennsylvanian megafloras of the Appalachian region. Review of Palaeobotany and Palynology, 95, pp. 255-283. http://dx.doi.org/10.1016/S00346667(96)00037-1

Wagner, R.H. and Talens, J. 1985. On the upper Westphalian and Stephanian species, Lepidodendron dissitum Sauveur. In Papers on the Carboniferous of the Iberian Peninsula. Edited by M.J. Lemos de Sousa and R.H. Wagner. Anais Faculdade de Ciências, Universidade do Porto, Supplement Vol. 64 (1983), pp. 435-444.

Wagner, R.H., Brousmiche-Delcambre, C., and Coquel, R. 2003. Una Pompeya Paleobotánica: historia de una marisma carbonífera sepultada por cenizas volcánicas. In Patrimonio Geológico de Castilla-La Mancha. Edited by R. Nuche. ENRESA, Madrid, pp. 448-475.

Wagner, R.H., Diez, B. and Sánchez-Pellicer, R. 2012. Las huellas de un bosque carbonífero: una colonización costera y su ocaso. Geotemas, 13, pp. 179-182.

Witham, H.T.M. 1833. The Internal Structure of Fossil Vegetables found in the Carboniferous and Oolitic deposits of Great Britain. Edinburgh, $84 \mathrm{p}$.

White, D. 1898. Omphalophloios, a new Lepidodendroid type. Bulletin of the Geological Society of America, 9, pp. 329-342.

White, D. 1899. Fossil Flora of the Lower Coal Measures of Missouri. United States Geological Survey, Monographs, XXXVII, pp. 1-467.

White, D. 1937. Fossil Flora of the Wedington Sandstone Member of the Fayetteville Shale. Shorter contributions to general geology, 1936. U.S. Geological Survey, Professional Paper 186-B, pp. 13-40.

Willard, D.A., DiMichele, W.A., Eggert, D.L., Hower, J.C., Rexroad, C.B., and Scott, A.C. 1995. Paleoecology of the Springfield Coal Member (Desmoinesian, Illinois Basin) near the Leslie Cemetery paleochannel, southwestern Indiana. International Journal of Coal Geology, 27, pp. 59-98. http://dx.doi.org/10.1016/0166-5162(94)00015-R

Wittry, J. 2006. The Mazon Creek Fossil Flora. Earth Science Club of Northern Illinois, Esconi Associates, Illinois, 154 p.

Wnuk, C. 1985. The ontogeny and paleoecology of Lepidodendron rimosum and Lepidodendron bretonense trees from the Middle Pennsylvanian of the Bernice Basin (Sullivan County, Pennsylvania). Palaeontographica, Abt. B, 195, pp. 153-181.

Wood, H.C. 1860. Contributions to the Carboniferous Flora of the United States. Proceedings of the Academy of Natural Sciences of Philadelphia, XII, pp. 236-240.

Wood, H.C. 1869. A Contribution to the Knowledge of the 
Flora of the Coal Period in the United States. Transactions of the American Philosophical Society, New Series, 13 (3), pp. 341-349.

Wood, J.M. 1963. The Stanley Cemetery Flora (Early Pennsylvanian) of Greene County, Indiana. Indiana Department of Conservation, Geological Survey, Bulletin 29, pp. 1-73.

Zalessky, M. 1904. Végétaux fossiles du terrain carbonifère $\mathrm{du}$ Bassin du Donetz. I. Lycopodiales. Mémoires du Comité géologique, Nouvelle série, 13, pp. 1-126. (In Russian and French).

Zalessky, M.D. 1907. Contributions à la flore fossile du terrain houiller du Donetz. II. Plantes fossiles de l'Institut géologique de l'Université Impériale de Kharkow et du Musée du Don à Novotcherkask. Bulletins du Comité Géologique, XXVI (135), pp. 423-494. (In Russian with comments in French).

Zeiller, R. 1886-1888. Bassin houiller de Valenciennes. Description de la flore fossile. Études des Gîtes Minéraux de la France. Texte (1888): 1-729. Atlas (1886): pls IXCIV.

Zodrow, E.L. and McCandlish, K. 1980. Upper Carboniferous Fossil Flora of Nova Scotia In the Collections of the Nova Scotia Museum, with Special Reference to the Sydney Coalfield. The Nova Scotia Museum, Halifax, 275 p.

Editorial responsibility: Robert A. Fensome

\section{APPENDIX: TAXON LIST}

Achlamydocarpon varius (Baxter) Taylor and Brack-Hanes Anabathra Witham

Anabathra landsburgii (Kidston) Pearson

Anabathra pulcherrima Witham emend. Pearson

Annularia ramosa Weiss

Asolanus camptotaenia Wood

Aspidiaria Presl in Sternberg

Bergeria Presl in Sternberg

Bergeria acuta Presl in Sternberg

Bergeria angulata Presl in Sternberg

Bergeria dilatata (Lindley and Hutton) comb. nov. herein

Bergeria marginata Presl in Sternberg

Bergeria quadrata Presl in Sternberg

Bergeria rhombica Presl in Sternberg

Bergeria worthenii (Lesquereux) comb. nov. herein

Bothrodendron Lindley and Hutton

Calamites suckowii Brongniart

Clathraria Brongniart

Cordaites Unger emend. Ledran

Cyperites Lindley and Hutton

Cyperites bicarinatus Lindley and Hutton

Diaphorodendron DiMichele emend. DiMichele and Bateman
Diaphorodendron bretonense (Bell) Bashforth

Diaphorodendron decurtatum (Dawson) comb. nov. herein

Diaphorodendron scleroticum (Pannell) DiMichele

Diaphorodendron vasculare (Binney) DiMichele

Dorycordaites palmaeformis (Göppert) Grand'Eury

Eusphenopteris neuropteroides (Boulay) Novik

Eusphenopteris sauveurii (Crépin) Simson-Scharold

Favularia Sternberg

Filicites (Glossopteris) dubius Brongniart

Flemingites Carruthers emend. Brack-Hanes and Thomas

Flemingites gracilis Carruthers

Flemingites olryi (Zeiller) Brack-Hanes and Thomas

Flemingites russelianus (Binney) Brack-Hanes and Thomas

Gymnostrobus salisburyi (Lesquereux) Bureau

Halonia tortuosa Lindley and Hutton

Hizemodendron Bateman and DiMichele

Lagenicula Bennie and Kidston

Lagenoisporites Potonié and Kremp

Laveineopteris polymorpha (Dawson) Wagner

Leiodermaria Goldenberg

Lepidocarpon majus (Brongniart) Hemingway

Lepidodendron Sternberg

Lepidodendron aculeatum Sternberg

Lepidodendron acutum (Presl in Sternberg) Kidston

Lepidodendron andrewsii Lesquereux

Lepidodendron anglicum Sternberg

Lepidodendron arberi Thomas

Lepidodendron bellii sp. nov.

Lepidodendron bordae Wood

Lepidodendron bretonense Bell

Lepidodendron brittsii Lesquereux

Lepidodendron carinatum Lesquereux

Lepidodendron clypeatum Lesquereux

Lepidodendron conicum Lesquereux

Lepidodendron costaei Sauveur

Lepidodendron crenatum Sternberg

Lepidodendron croftii Stockmans and Willière

Lepidodendron cyclostigma Lesquereux

Lepidodendron dawsonii Bell

Lepidodendron decurtatum Dawson

Lepidodendron dichotomum Sternberg

Lepidodendron dichotomum var. bretonensis Bell

Lepidodendron dicrocheilum Wood

Lepidodendron dilatatum Lindley and Hutton

Lepidodendron dissitum Sauveur

Lepidodendron elongatum Brongniart

Lepidodendron feistmantelii Zalessky

Lepidodendron fusiforme (Corda) Unger

Lepidodendron giganteum Lesquereux

Lepidodendron gracile Lindley and Hutton

Lepidodendron grigorievii Zalessky

Lepidodendron haidingeri Ettingshausen

Lepidodendron hickii Watson

Lepidodendron jaraczewskii Zeiller 
Lepidodendron lanceolatum Lesquereux

Lepidodendron landsburgii Kidston

Lepidodendron laricinum Sternberg

Lepidodendron latifolium Lesquereux

Lepidodendron lesquereuxii Wood

Lepidodendron loricatum Arber

Lepidodendron lossenii Weiss

Lepidodendron lycopodioides Sternberg

Lepidodendron magnum Wood

Lepidodendron mannebachense Presl in Sternberg

Lepidodendron marginatum (Presl in Sternberg) Goldenberg

Lepidodendron mekiston Wood

Lepidodendron modulatum Lesquereux

Lepidodendron obovatum Sternberg

Lepidodendron obovatum var. grandifolium Kosanke

Lepidodendron obtusum Sauveur

Lepidodendron obtusum Lesquereux (non Sauveur)

Lepidodendron ophiurioides Arnold

Lepidodendron ophiurus (Brongniart) Brongniart

Lepidodendron oweni Wood

Lepidodendron paucipunctatum Stockmans and Willière

Lepidodendron pictoense Dawson

Lepidodendron plicatum Dawson

Lepidodendron rhombicum (Presl in Sternberg) Goldenberg

Lepidodendron rimosum Sternberg

Lepidodendron rimosum var. retocorticatum White

Lepidodendron scutatum Lesquereux

Lepidodendron selaginoides Sternberg

Lepidodendron simile Kidston

Lepidodendron simplex Lesquereux

Lepidodendron sternbergii Brongniart

Lepidodendron subdichotomum Sterzel

Lepidodendron taxandricum Stockmans and Willière

Lepidodendron tetragonum Sternberg

Lepidodendron tijoui Lesquereux

Lepidodendron uraeum Wood

Lepidodendron veltheimii Sternberg

Lepidodendron venustum Wood

Lepidodendron vestitum Lesquereux

Lepidodendron volkmannianum Sternberg

Lepidodendron wedingtonense White

Lepidodendron wilmingtonii Langford

Lepidodendron worthenii Lesquereux

Lepidophloios Sternberg

Lepidophloios acadianus Dawson

Lepidophloios acerosus Lindley and Hutton

Lepidophloios auriculatus Lesquereux

Lepidophloios dilatatus Lesquereux

Lepidophloios laricinus (Sternberg) Sternberg

Lepidophloios macrolepidotus Goldenberg

Lepidophloios obcordatus Lesquereux

Lepidophloios parvus Dawson

Lepidophloios prominulus Dawson

Lepidophloios vaningenii White
Lepidophylloides Snigirevskaya

Lepidophylloides morrisianus (Lesquereux) Crookall

Lepidophyllum Brongniart (name illegitimate)

Lepidophyllum acuminatifolium Stockmans and Willière

Lepidophyllum acuminatum Lesquereux

Lepidophyllum auriculatum Lesquereux

Lepidophyllum fallax Lesquereux

Lepidophyllum glossopteroides Göppert

Lepidophyllum intermedium Lindley and Hutton

Lepidophyllum lanceolatum Lindley and Hutton

Lepidophyllum mansfieldii Lesquereux

Lepidophyllum majus Brongniart

Lepidophyllum morrisianum Lesquereux

Lepidophyllum rostellatum Lesquereux

Lepidophyllum striatum Lesquereux

Lepidophyllum tieghemii (Zeiller) Jongmans in Wagner

Lepidostrobophyllum Hirmer

Lepidostrobophyllum acuminatum (Lesquereux) Crookall

Lepidostrobophyllum auriculatum (Lesquereux) Tidwell

Lepidostrobophyllum fallax (Lesquereux) Gastaldo

Lepidostrobophyllum fimbriatum (Kidston) Allen

Lepidostrobophyllum fletcheri Bell

Lepidostrobophyllum hastatum (Lesquereux) Chaloner and

Boureau in Boureau

Lepidostrobophyllum lanceolatum (Lindley and Hutton) Bell

Lepidostrobophyllum lanceolatum var. constrictum Bell

Lepidostrobophyllum lancifolium (Lesquereux) Oleksyshyn

Lepidostrobophyllum majus (Brongniart) Hirmer

Lepidostrobophyllum majus forma lanceolatum Lindley and

Hutton

Lepidostrobophyllum mansfieldii (Lesquereux) Langford

Lepidostrobophyllum missouriense (White) Basson

Lepidostrobophyllum morrisianum (Lesquereux) Tenchov

Lepidostrobophyllum moyseyi (Arber) Bell

Lepidostrobophyllum oblongifolium (Lesquereux) Langford

Lepidostrobophyllum ovatifolium (Lesquereux) Bell

Lepidostrobopsis missouriensis (White) Abbott

Lepidostrobus Brongniart emend. Brack-Hanes and Thomas

Lepidostrobus auriculatus Lesquereux

Lepidostrobus brongniartii Göppert in Berger

Lepidostrobus comosus Lindley and Hutton

Lepidostrobus dubius Binney

Lepidostrobus geinitzii Schimper

Lepidostrobus goodei Jongmans

Lepidostrobus hibbertianus Binney

Lepidostrobus kidstonii Zalessky

Lepidostrobus lanceolatus (Lindley and Hutton) Göppert

Lepidostrobus macrocystis Lesquereux (typographic error?)

Lepidostrobus oblongifolius Lesquereux

Lepidostrobus olryi Zeiller

Lepidostrobus ornatus Brongniart

Lepidostrobus russelianus Binney

Lepidostrobus (Macrocystis) salisburyi Lesquereux

Lepidostrobus squarrosus Kidston 
Lepidostrobus variabilis Lindley and Hutton

Lobatopteris vestita sensu Wagner

Lomatophloios intermedium Goldenberg

Lomatophloyos macrolepidotum Goldenberg

Lycospora Schopf, Wilson and Bentall

Mariopteris occidentalis White emend. Krings et al.

Omphalophloios White

Omphalophloios anglicus (Sternberg) Kidston

Omphalophloios cyclostigma (Lesquereux) White

Palmacites hexagonatus Schlotheim

Paralycopodites Morey and Morey emend. DiMichele

Paralycopodites brevifolius (Williamson) DiMichele

Polysporia Newberry

Rhytidolepis Sternberg

Sagenaria caudata Presl in Sternberg

Sagenaria coelata Brongniart

Sagenaria microstigma Feistmantel

Sagenaria obovata Presl in Sternberg

Sagenaria rugosa Presl in Sternberg

Senftenbergia plumosa (Artis) Stur

Sigillaria Brongniart

Sigillaria brardii Brongniart

Sigillaria brardii var. denudata Göppert

Sigillaria decheni Roehl

Sigillaria demanetii Stockmans and Willière

Sigillaria deutschii Brongniart

Sigillaria duacensis Boulay

Sigillaria elegans Sternberg

Sigillaria fundiensis Bell

Sigillaria hexagona (Schlotheim) Brongniart

Sigillaria laevigata Brongniart

Sigillaria mamillaris Brongniart

Sigillaria minima Brongniart

Sigillaria notata Brongniart

Sigillaria nudicaulis Boulay

Sigillaria orbicularis Brongniart

Sigillaria ovata Sauveur
Sigillaria palpebra Dawson

Sigillaria polyploca Boulay

Sigillaria reticulata Lesquereux

Sigillaria rugosa Brongniart

Sigillaria scutellata Brongniart

Sigillaria serlii Brongniart

Sigillaria subrotunda Brongniart

Sigillaria tessellata Brongniart

Sigillaria vermiculata Deltenre

Sigillariophyllum Grand'Eury

Sigillariostrobus Schimper

Sigillariostrobus goldenbergii Feistmantel

Sigillariostrobus tieghemii Zeiller

Sporangiostrobus Bode

Sphenophyllum emarginatum (Brongniart) Brongniart

Stigmaria Brongniart

Stigmaria areolata Dawson

Stigmaria elliptica Lesquereux

Stigmaria evenii Lesquereux

Stigmaria ficoides (Sternberg) Brongniart

Stigmaria ficoides var. stellata Göppert

Stigmaria ficoides var. undulata Göppert

Stigmaria ficoides var. minus Göppert

Stigmaria perlata Dawson

Stigmaria stellata Göppert

Synchysidendron DiMichele and Bateman

Syringodendron Sternberg

Ulodendron Lindley and Hutton

Ulodendron acutum (Presl in Sternberg) Álvarez-Vázquez

Ulodendron elongatum Lesquereux

Ulodendron goodei Stockmans and Willière

Ulodendron landsburgii (Kidston) Thomas

Ulodendron majus Lindley and Hutton

Ulodendron minus Lindley and Hutton

Ulostrobus goodei (Jongmans) Stockmans and Willière

Variolaria ficoides Sternberg

Zeilleria avoldensis (Stur) Kidston 